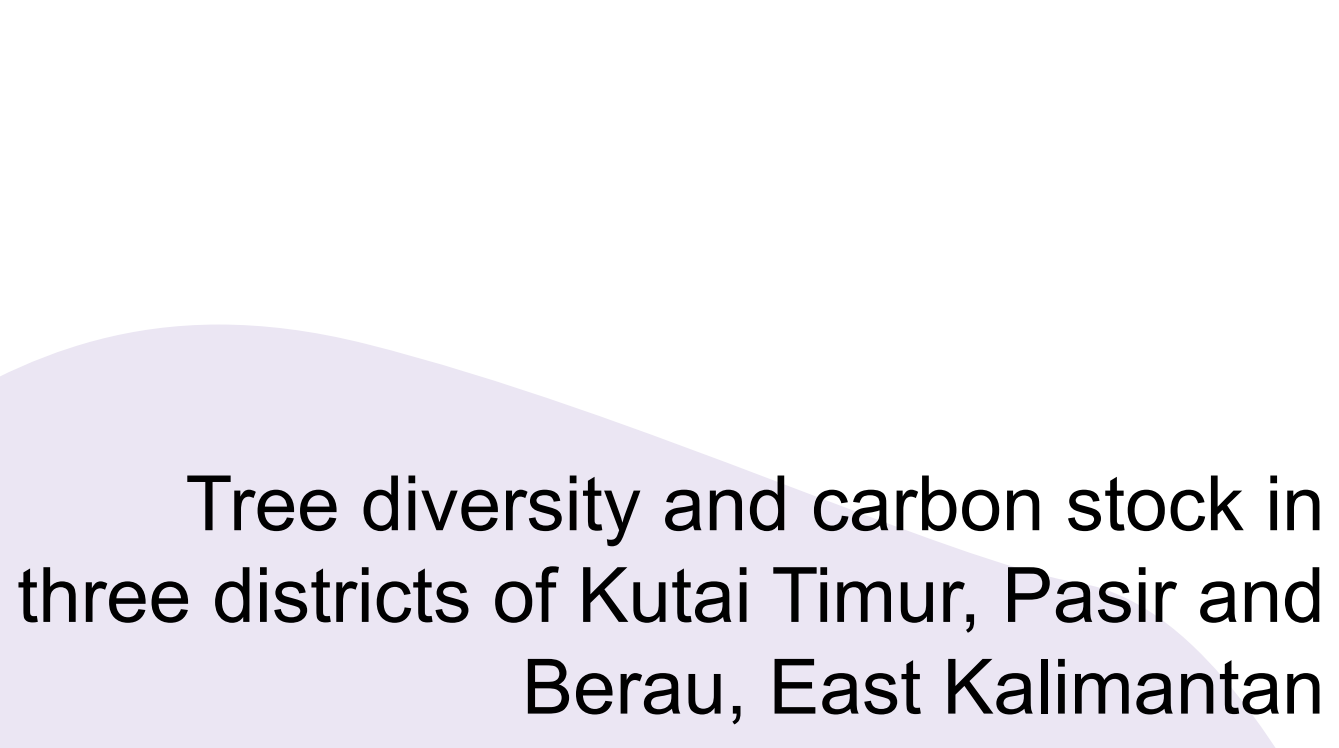

Tree diversity and carbon stock in Berau, East Kalimantan

Subekti Rahayu and Sidiq Pambudi 



\section{Tree diversity and carbon stock in three districts of Kutai Timur, Pasir and Berau, East Kalimantan}

Subekti Rahayu and Sidiq Pambudi 


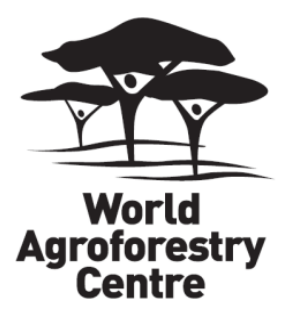

Correct citation

Rahayu S and Pambudi S. 2017. Tree diversity and carbon stock in three districts of Kutai Timur, Pasir and Berau, East Kalimantan. Working Paper 266. Bogor, Indonesia: World Agroforestry Centre (ICRAF) Southeast Asia Regional Program. DOI: http://dx.doi.org/10.5716/WP17357.PDF

Titles in the Working Paper series aim to disseminate interim results on agroforestry research and practices, and stimulate feedback from the scientific community. Other publication series from the World Agroforestry Centre include Technical Manuals, Occasional Papers and the Trees for Change Series.

Published by the World Agroforestry Centre

Southeast Asia Regional Program

JL. CIFOR, Situ Gede, Sindang Barang, Bogor 16680

PO Box 161, Bogor 16001, Indonesia

Tel: +62 2518625415

Fax: +62 2518625416

Email: icraf-indonesia@cgiar.org

ICRAF Southeast Asia website: http://www.worldagroforestry.org/region/southeast-asia/

(C) World Agroforestry Centre 2017

Working paper no. 266

Photos/illustrations: the authors

\section{Disclaimer and copyright}

The views expressed in this publication are those of the author(s) and not necessarily those of the World Agroforestry Centre.

Articles appearing in this publication may be quoted or reproduced without charge, provided the source is acknowledged.

All images remain the sole property of their source and may not be used for any purpose without written permission of the source. 


\section{About the authors}

Subekti Rahayu is a biodiversity and carbon stock specialist at the World Agroforestry Centre. Her main areas of interest include biodiversity conservation, forest and landscape restoration, forest ecology, bioindicators and agroforestry ecology. She is a $\mathrm{PhD}$ candidate on restoration model in Samboja Research Forest, East Kalimantan. She has a master degree in Tropical Biodiversity Conservation from Bogor Agriculture University. She holds a bachelor degree from the same university, majoring in Plant Protection. She has had experience with carbon-stock measurement at plot level since 1998 and delivering training on the subject to various institutions in Indonesia and to local communities in Indonesia and Viet Nam since 2002. Contact: s.rahayu@ @ cgiar.org.

Sidiq Pambudi is research assistant in World Agroforestry Centre Indonesia. His areas of work generally on biodiversity assessment in various land use including analysis vegetation and aboveground carbon stock estimation. Aside from working on field work surveys, analyzing and interpreting data, he has also conducts trainings, and develops reports and briefs. Sidiq also passionate in wildlife study and experienced in conducting fauna inventory in various activity before joining World Agroforestry Centre. He received bachelor degree in Biology from Institut Teknologi Bandung in 2012, focusing on ecology and biosystematics research group. Contact: s.pambudi@cgiar.org 


\section{Abstract}

East Kalimantan is known as rich of natural resources, both renewable product of high value timber and non-renewable of mineral fuels and coal. Forest degradation occurred in the area due to timber extraction and followed by repeated forest fire. Nowadays, monoculture plantation and coal mining as particular threat for forest cover in East Kalimantan, even in the protected area for economic development reason. Environmental friendly land use planning is an important strategy to achieve sustainable development. Tree diversity and carbon stock as environmental indicator is part of component should be assessed as land use planning input. Amount of 71 plots of 20 x $100 \mathrm{~m}$ in 22 land use systems in Berau, Kutai Timur and Pasir were set up to observe tree diversity composition and carbon stock estimation. Higher tree species richness and diversity found in natural ecosystems such as undisturbed forest, logged-over forest, except mangrove that only few species owing to specific characteristic on the ecosystem where allowed limited species to grow. Monoculture systems commonly hold less tree species in the systems depend on the management. Low intensive management contains higher tree species richness and diversity. Natural ecosystems of undisturbed forest, logged-over forest and low intensive management of fruit-based agroforest consist of higher carbon stock than monoculture systems.

\section{Keywords}

East Kalimantan, carbon stock, sustainable development, tree diversity 


\section{Content}

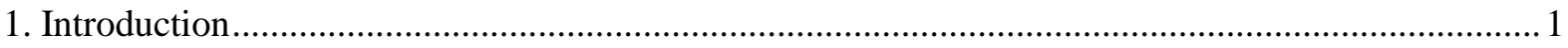

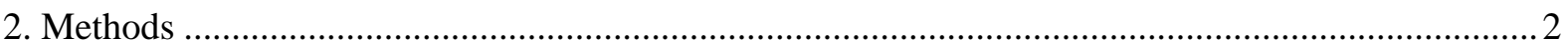

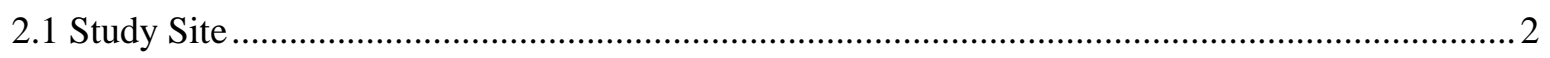

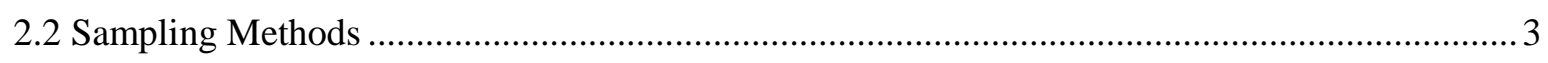

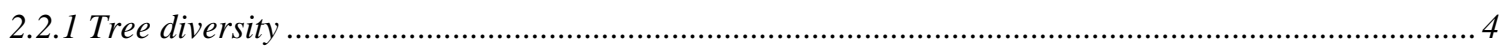

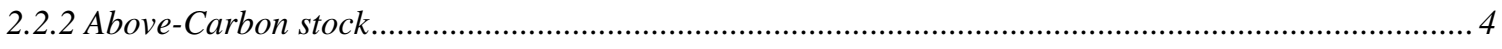

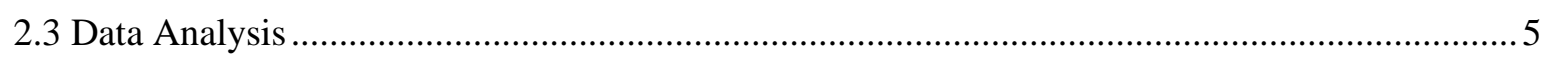

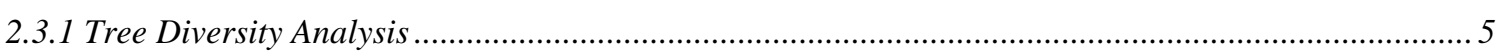

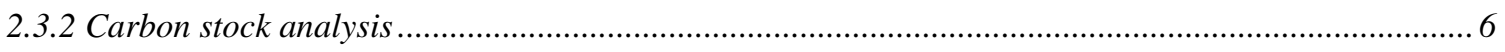

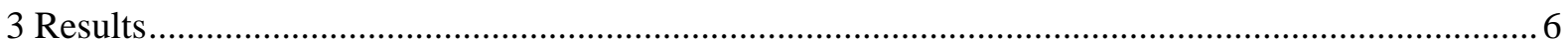

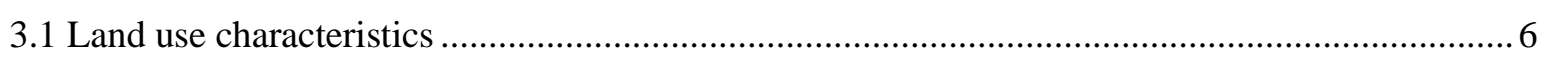

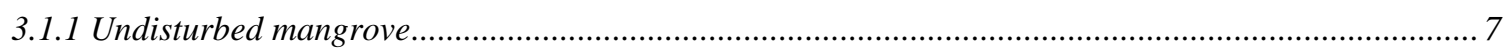

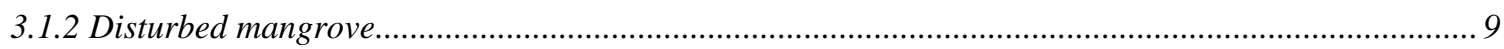

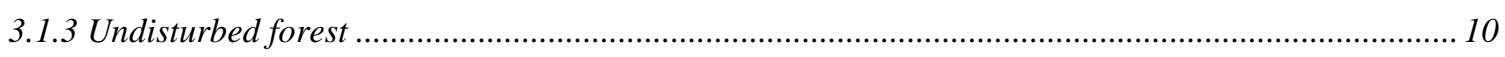

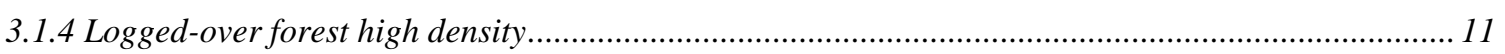

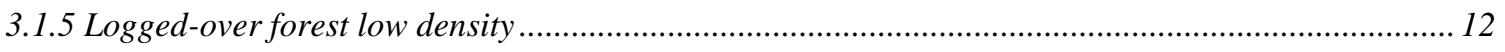

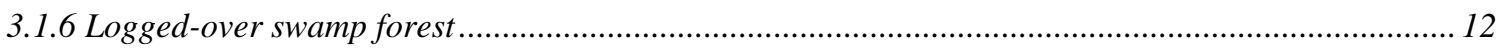

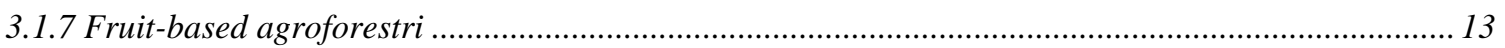

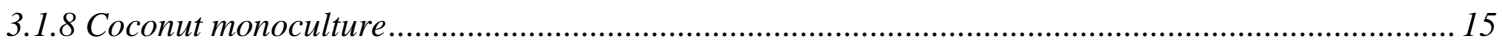

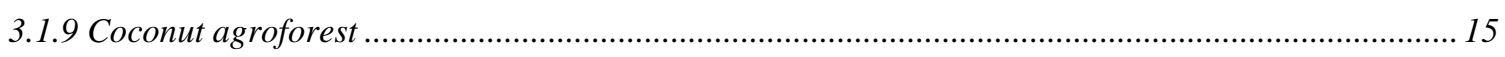

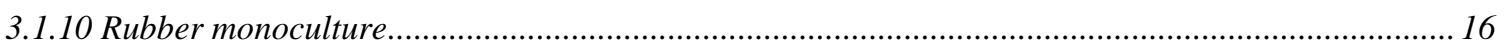

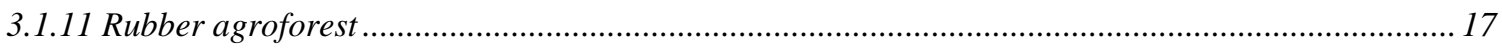

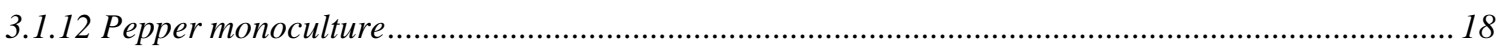

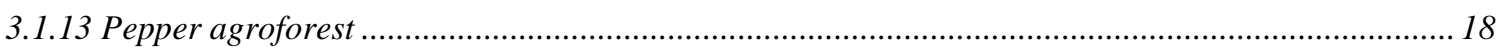

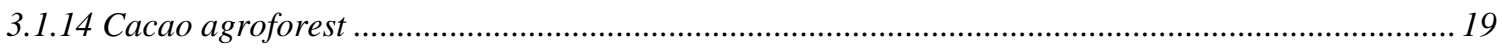

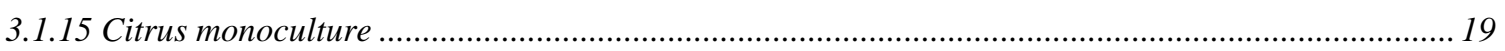

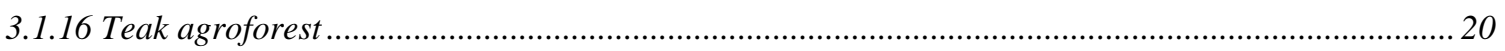

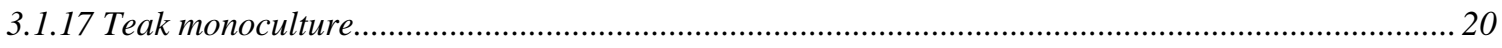

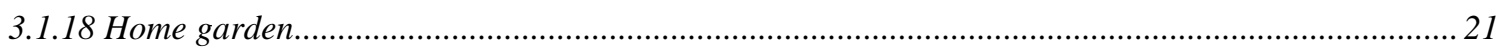

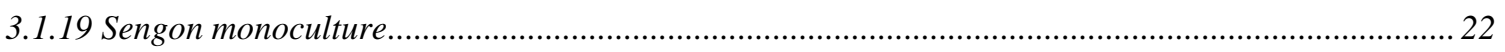

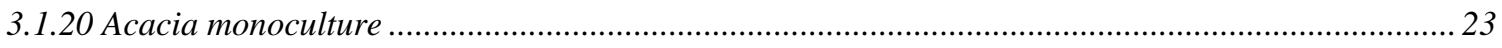

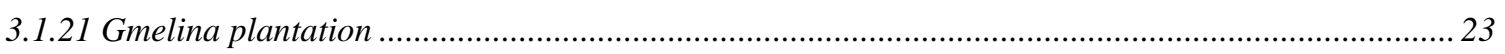

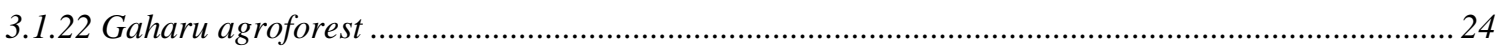

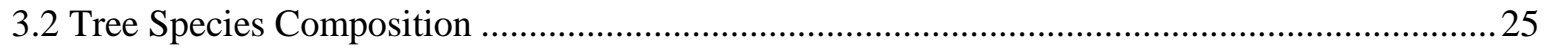

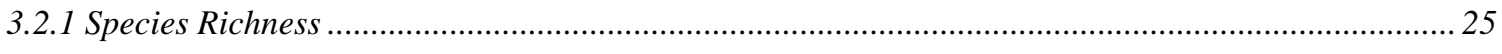

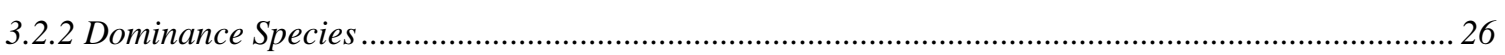

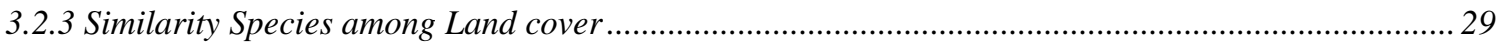




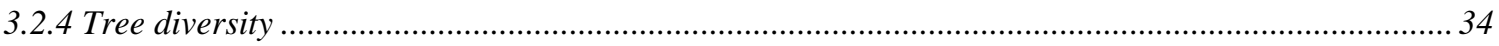

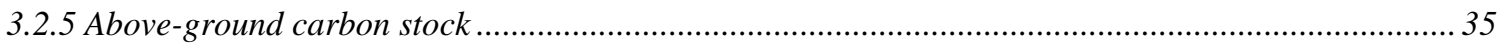

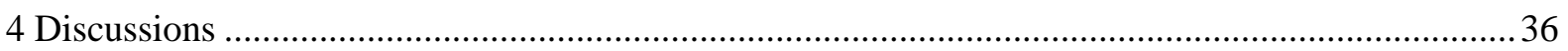

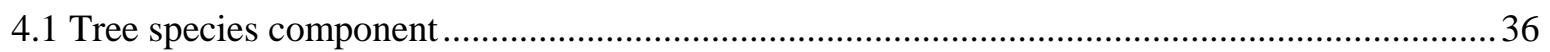

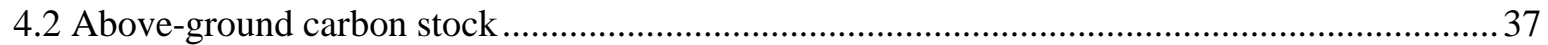

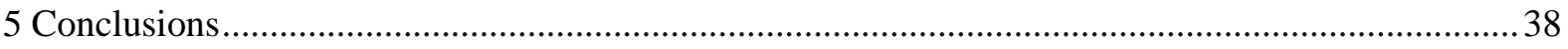

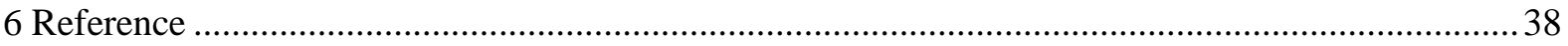




\section{List of Tables}

Table 1. Allometric equations for biomass estimation of specific species

Table 2. Number of sampled plot in each land cover systems of Berau, Kutai Timur and Pasir District, East Kalimantan in 2015-2016

Table 3.Tree species richness in various land use types of Kutai Timur, Pasir and Berau District,

Eat Kalimantan

Table 4. Three highest IVI species of all growth stages in various land cover systems in Kutai Timur, Pasir and Berau District, East Kalimantan.

Table 5. Similarity matrix of species among land uses systems in each growth stage in Kutai Timur....

Table 6. Similarity matrix of species among land uses systems in each growth stage in Pasir.

Table 7. Similarity matrix of species among land uses systems in each growth stage in Berau 33

Table 8. Shannon-Wiener diversity index in various land cover systems for all growth stages in Kutai Timur, Pasir and Berau .

Table 9. Above-ground carbon stock of four carbon pool and total carbon stock in various land use types in Kutai Timur, Pasir and Berau District

\section{List of Figures}

Figure 1. Study site (bright green area)

Figure 2. Land uses systems in three district of Kutai Timur (1), Pasir (2) and Berau (3) ............................ 3

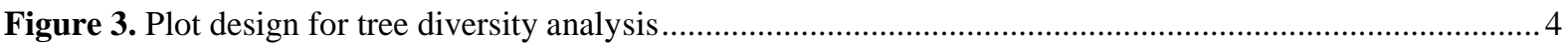

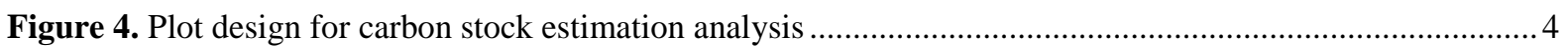

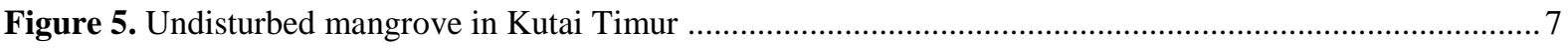

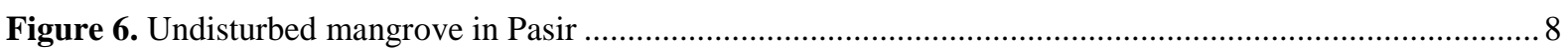

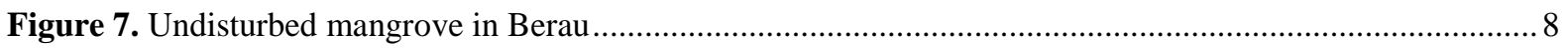

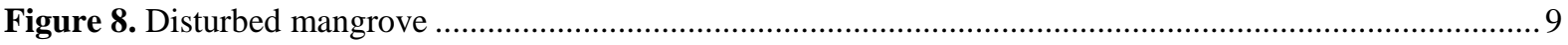

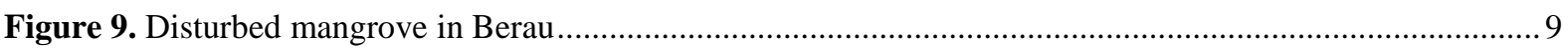

Figure 10. Undisturbed forest in Gunung Lumut protected forest of Pasir................................................... 10

Figure 11. Undisturbed forest of Sungai Lesan protected forest, Berau ................................................. 10

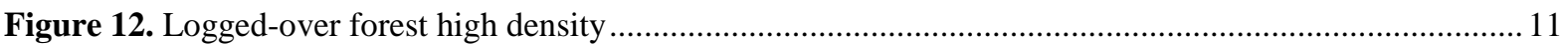

Figure 13. Logged-over forest high density in Hutan Lindung Sungai Lesan (left) and Hutan Lindung Dumaring (right), Berau

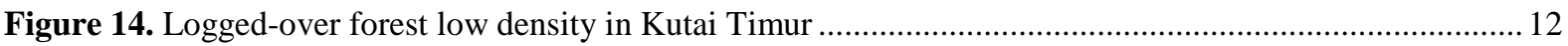

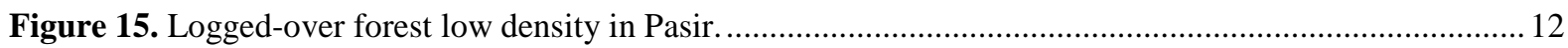

Figure 16. Heterogenous logged-over swamp forest in Jone (left), homogenous logged-over swamp forest in Rantau Panjang (right), Pasir

Figure 17. Fruit-based agroforestry in Miau Baru (left), and rambutan plantation in Sangatta (right) .............. 13

Figure 18. Durian plantation (left), fruit-based agroforest (right) in Pasir................................................... 14

Figure 19. Various types of fruit-base agroforestry in Berau ............................................................... 14

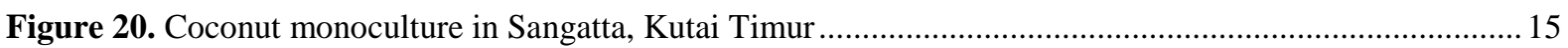


Figure 21. Coconut agroforest in Berau

Figure 22. Rubber monoculture in Kutai Timur, Young rubber 3 - 4 years (left), > 10 years (center),

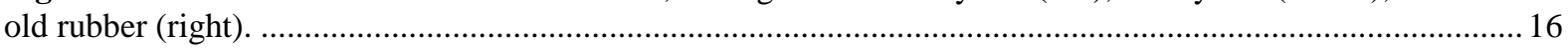

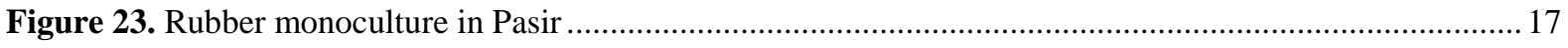

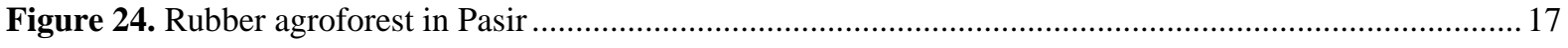

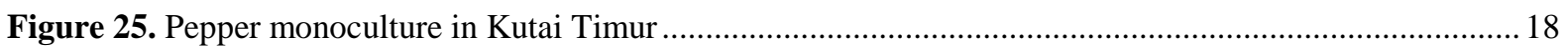

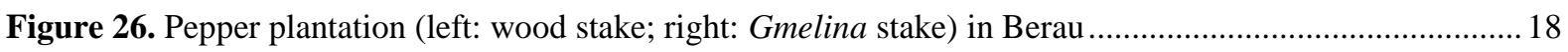

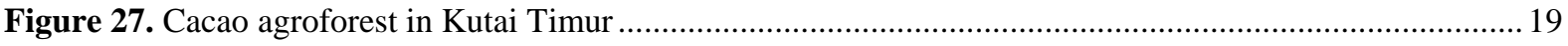

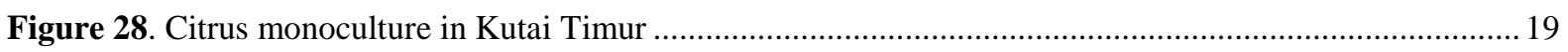

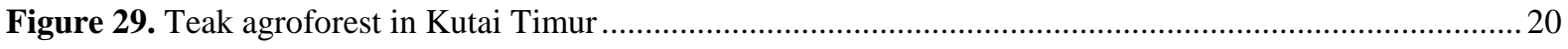

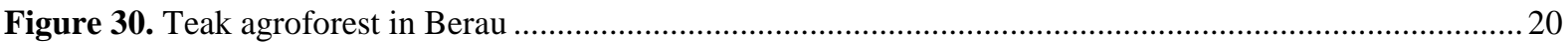

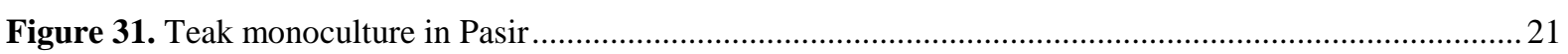

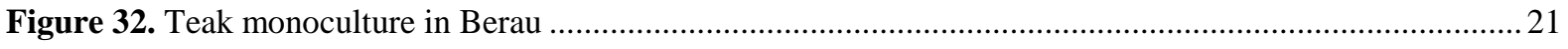

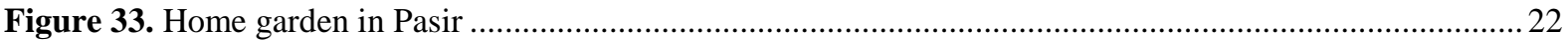

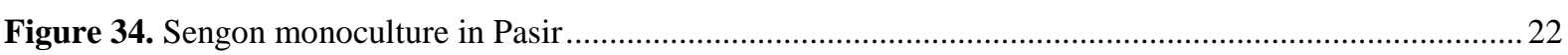

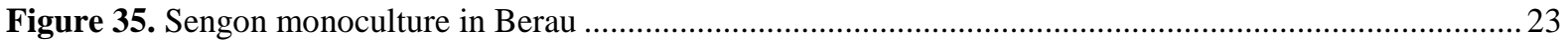

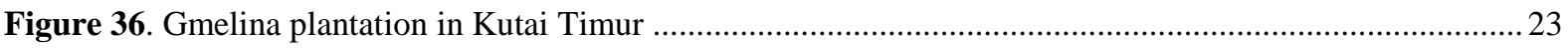

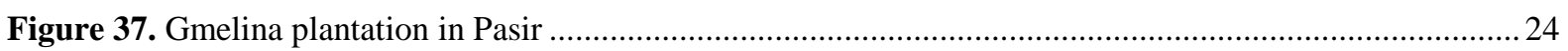

Figure 38. Gmelina plantation in Biatan (left) and in PT Sumalindo Alam Lestari (right), Berau ...................24

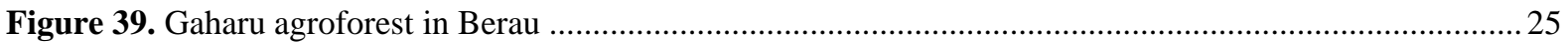




\section{Introduction}

East Kalimantan province is known as high potential of natural resources in Indonesia. Lowland tropical forest in East Kalimantan was also known as the richest tree species (Kartawinata et al 2008) and habitat of high value timber from Dipterocarp and ulin (Delmy 2001). Logging concession was the main factor removing most of forest cover in the area. Since the collapse of its timber industry in the 1990s, the provincial economy has been heavily dependent on the mining sector. Charcoal mining is another natural resources option in East Kalimatan. Mining industry not only operates in non forest area, but also in the forested land, even in protected forest. The dependency on nonrenewable resources has not produced sustainable growth, which East Kalimantan are experiencing the real impacts of deforestation.

Major forest fires of 1982/1983 and 1997/1998 in East Kalimantan was multiplier effect of forest degradation, deforestation and long drought period due to El Nino, then direct affect to tree stand and biodiversity loss. Furthermore, environmental services, such as carbon sequestration, hydrological regulation will also loss. Land uses change to settlement, infrastructures development, monoculture plantation established by private companies and smallholder widely spread due to political changes situation.

Land-based economic activities are major source of economic welfare in Indonesia (GE-LAMA-I 2016), and increase significantly after autonomy era. Conversely, natural land cover conversion, mostly forest, through land use, land-use change including burning peat land were the causes of around 60\% of Indonesia greenhouse gas emission in 2000 (GE-LAMA-I 2016; Harris et al 2012). However, with the existing economic development targets, Indonesia has committed to reduce greenhouse gas emission by $26 \%$ unilaterally or by $41 \%$ with international support from business as usual levels by 2020 .

East Kalimantan Provincial Government has declared a plan to transform its economy into a green economy through reducing emissions while achieving economic development target. It aims to raise the share of renewable energy, create more value in the region through green industrial zones, and increase the contribution of innovative low-emission economic activities. Expected outcomes are greater prosperity for its people and the conservation of its nature. Landscape management planning is a concern for balancing social-economic needs with environmental sustainability. Therefore, an assessment of socio-economic and environment characteristics is needed for planning.

Green Economy and Locally-Appropriate Mitigation Actions in Indonesia (GE-LAMA-I) is an initiative for building local government capacities in low emission development planning and developing locally and/or nationally appropriate mitigation actions. Related to low emission development planning, baseline data of current and the past land cover condition, carbon stock in various land use systems and tree biodiversity as environment indicators are part of the input of planning development. The aims of the assessment: (1) to inventory tree diversity across land use system and (b) to estimate the carbon stock in various tree-based systems. 


\section{Methods}

\subsection{Study Site}

The assessment was covered in three districts of Kutai Timur (June 2015), Pasir (November 2015) and Berau (August 2016), East Kalimantan (Figure 1). Amount of 71 plots were set up in 23 selected land use systems where available in those three districts (Figure 2), 28 plots in Kutai Timur, 26 plots in Pasir and 17 plots in Berau.

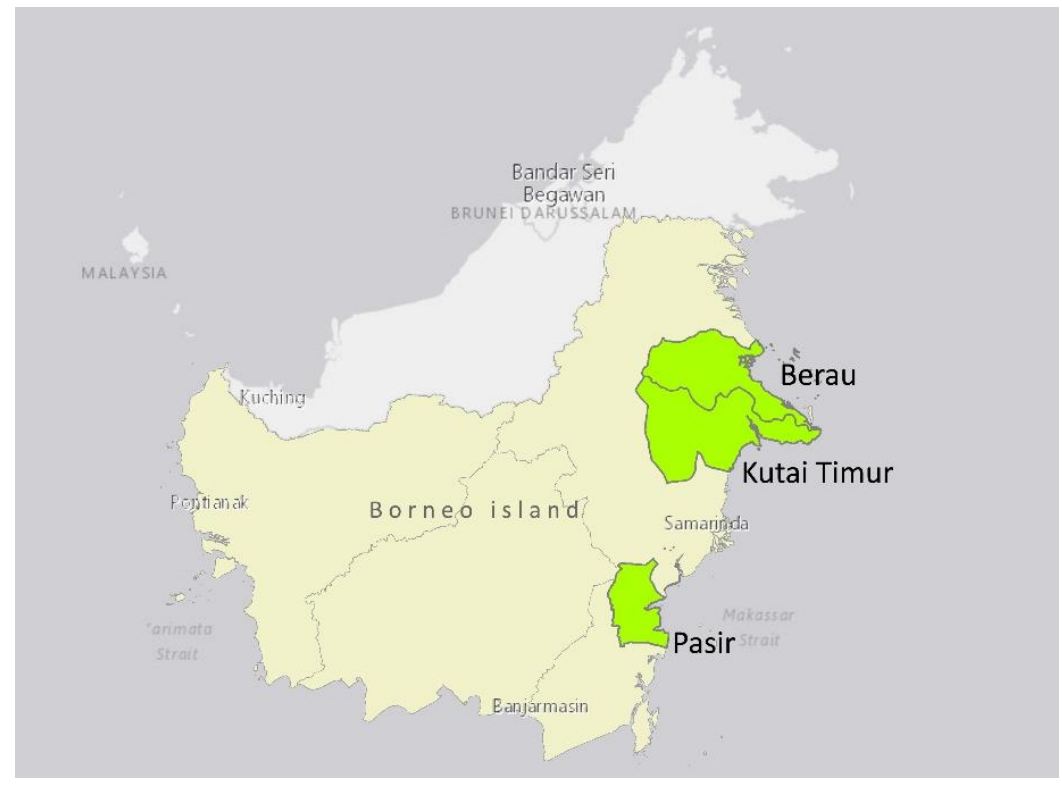

Figure 1. Study site (bright green area)

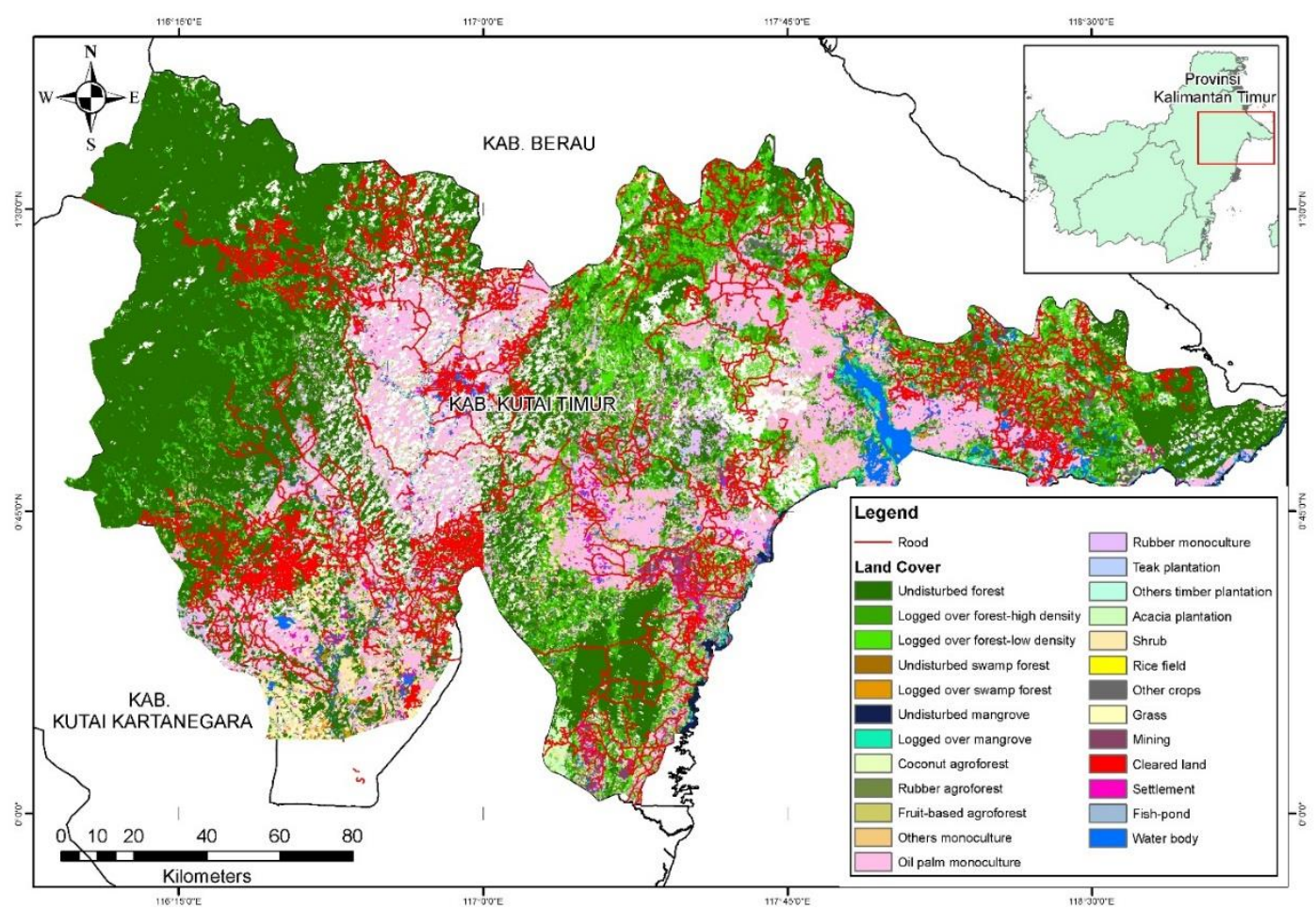



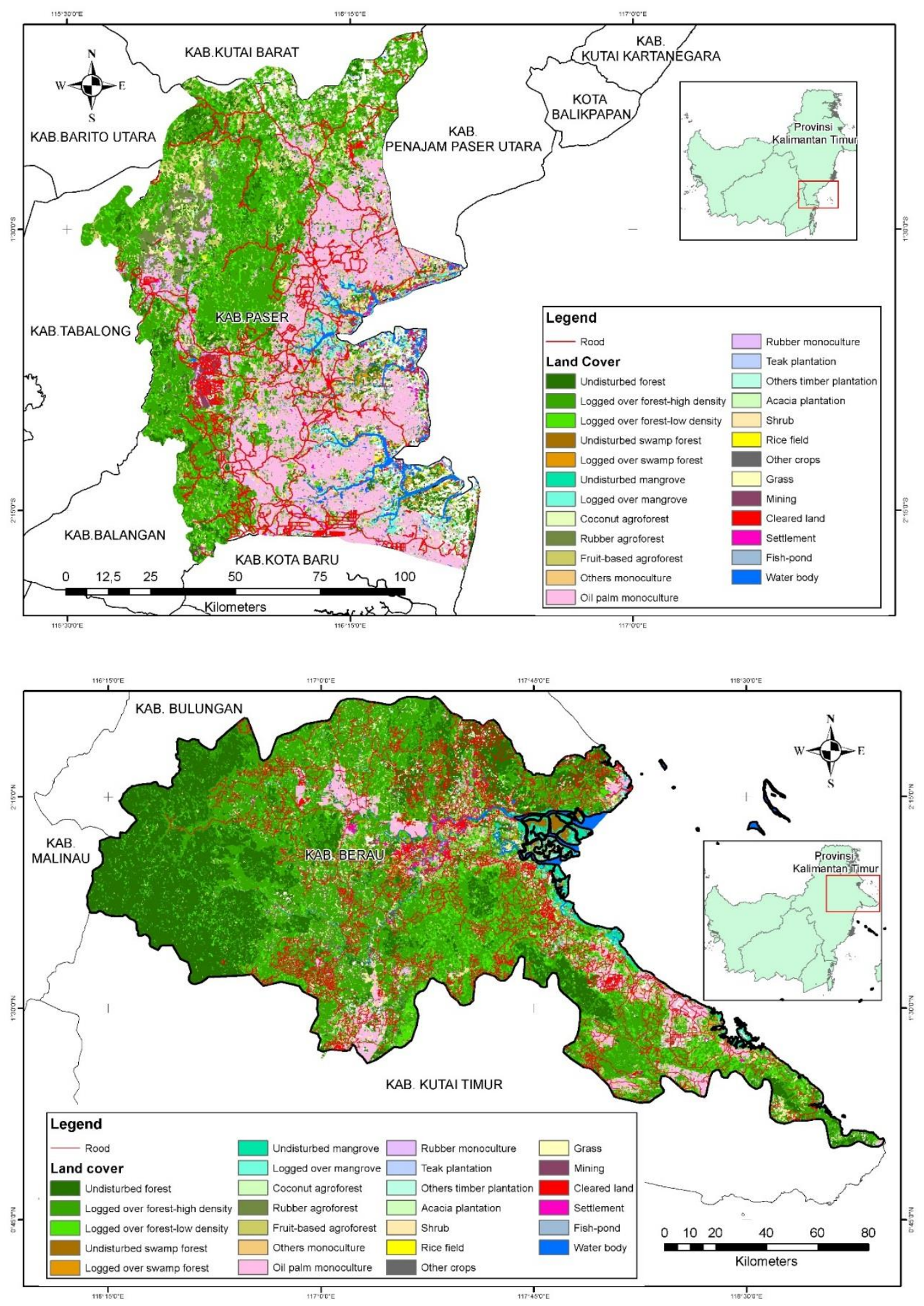

Figure 2. Land uses systems in three district of Kutai Timur (1), Pasir (2) and Berau (3)

\subsection{Sampling Methods}

Tree diversity sampling was done in the same plot of carbon stock. Modified plot size to $5 \times 20$ x 20 meters with nested of smaller plot (Figure 3) used to sampling tree diversity. Carbon stock estimation 
use method as described in Hairiah et al (2011). The $2000 \mathrm{~m}^{2}$ plot of $20 \times 100$ meters was placed in the targeted land cover (Figure 4).

\subsubsection{Tree diversity}

Four stages of vegetation growth, they are seedling ( $<2 \mathrm{~m}$ height), sapling ( $>2 \mathrm{~m}$ height, $<5 \mathrm{~cm}$ stem diameter), pole (5 $-10 \mathrm{~cm}$ diameter) and tree ( $>10 \mathrm{~cm}$ diameter) included in the analysis. Sampling was done in nested plot of $2 \mathrm{~m} \times 2 \mathrm{~m}$ for seedling, $5 \mathrm{~m} \times 5 \mathrm{~m}$ for sampling, $10 \mathrm{~m} \times 10 \mathrm{~m}$ for pole and $20 \times 20 \mathrm{~m}$ for tree.

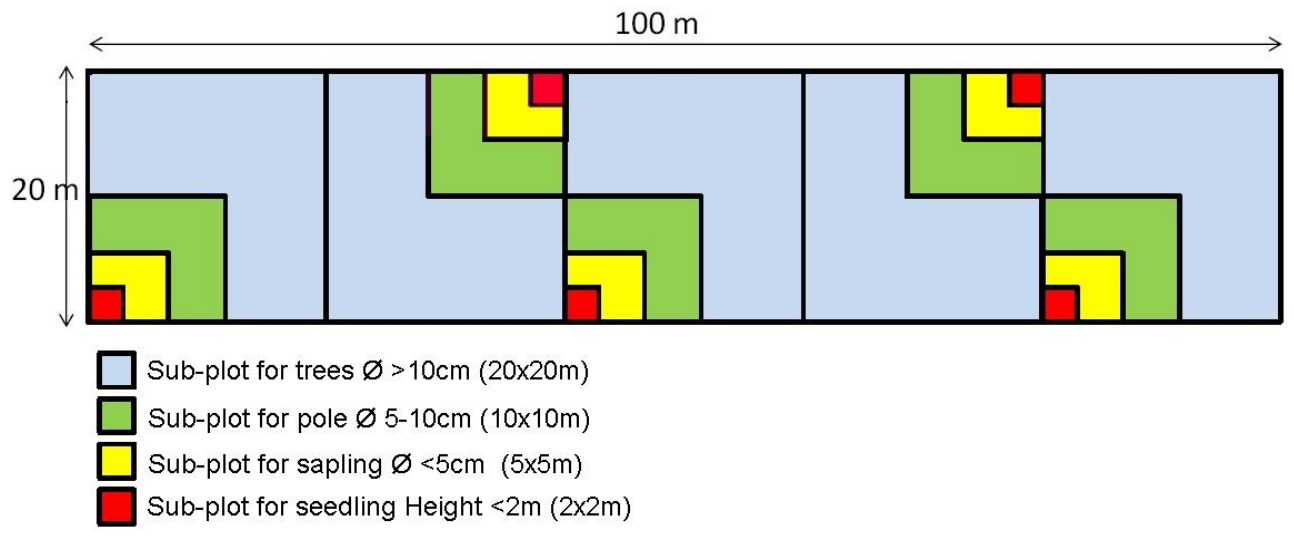

Figure 3. Plot design for tree diversity analysis

All seedling and sapling included in the plot samples were enumerated and each species was identified. All diameter stem of pole and tree in the plot samples were measured at breast height (1.3 meters above ground surface/DBH) and identified. Leaves specimens of all species were collected and identified in Herbarium Bogoriense.

\subsubsection{Above-Carbon stock}

Four carbon pools, they are: tree biomass, understorey, tree necromass and litter included in the assessment. Biomass estimation for large living and dead trees above $30 \mathrm{~cm}$ were measured in $20 \mathrm{x}$ $100 \mathrm{~m}^{2}$ plot, while the smaller living and dead trees $5-30 \mathrm{~cm}$ diameter were measured in $40 \times 5 \mathrm{~m}^{2}$ (Figure 4) through measuring DBH. Decomposition factor of dead tree were estimated based on visual performance.

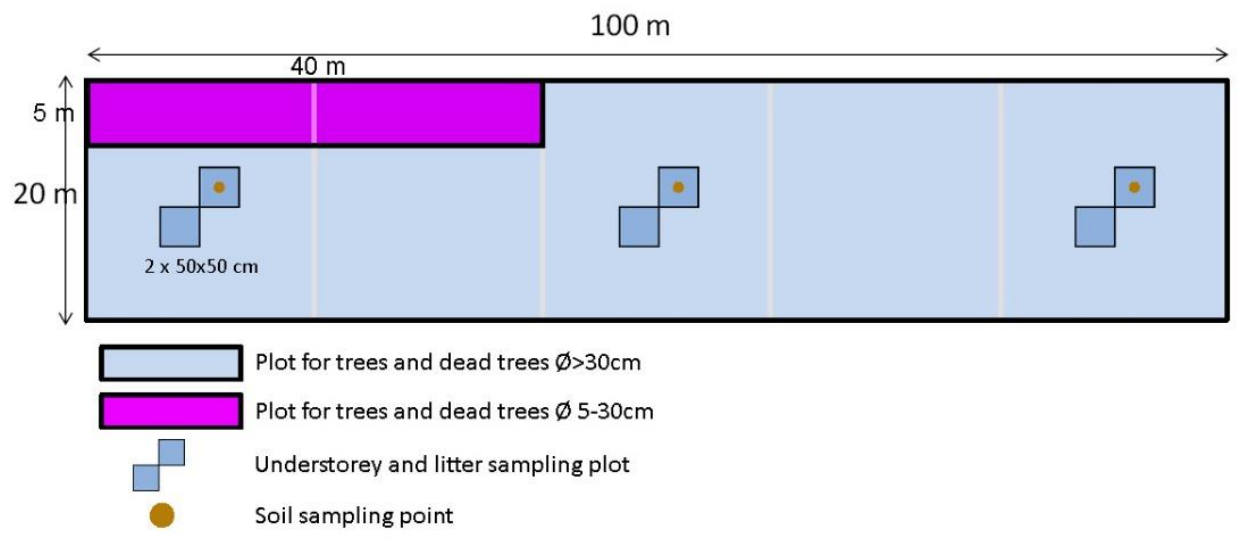

Figure 4. Plot design for carbon stock estimation analysis 
Understorey and litter sampling were conducted in a set quadrant $2 \times 0.5 \times 0.5 \mathrm{~m}^{2}$ where placed randomly inside $20 \mathrm{~m}$ x $100 \mathrm{~m}$ plot, minimum 3 replications in each plot. Fresh and dry weights of undertorey and litter samples were used in this analysis.

\subsection{Data Analysis}

\subsubsection{Tree Diversity Analysis}

Species richness, important value index (IVI), similarity index using Bray-Curtis dissimilarity and Shannon's diversity index used as tree diversity analysis. Species richness is number of different species represented in an ecological community, landscape or region (Colwell 2009). Important Value Index (IVI) expressed dominance species in the unit area that calculate based on relative frequency, relative density and relative dominance (Curtis \& McIntosh 1950):

$$
I V I=\text { Relative Frequency }+ \text { Relative Density }+ \text { Relative Dominance }
$$

a. Relative frequency: Frequency of species $i=\frac{\text { Number of quadrats species } i}{\text { Total number of quadrat sampled }}$

$$
\text { Relative Frequency }=\frac{\text { Frequency of species } i}{\text { Total Frequency }}
$$

b. Relative density: Density of species $i=\frac{\text { Number of species } i}{\text { Area of quadrat sampled }}$

$$
\text { Relative Density }=\frac{\text { Density of species } i}{\text { Total density }}
$$

c. Relative dominance: Dominance (Basal area of species $i)=\frac{\pi *(\text { Diameter of species } i)^{2}}{4}$

$$
\text { Relative Dominance }=\frac{\text { Basal area of species } i}{\text { Total basal area }}
$$

The Bray-Curtis dissimilarity (B) is a statistic used to quantify the compositional dissimilarity between two different sites, based on counts at each site. Bray-Curtis dissimilarity were using the individual number as parameter in the calculation, so that both of species and individual parameters affecting the degree of similarity of two compared sites.

$$
\text { Bray-Curtis similarity }(1-B)=1-\frac{\sum_{i=1}^{S}\left|\left(n_{1 i}-n_{2 i}\right)\right|}{\sum_{i=1}^{S}\left(n_{1 i}+n_{2 i}\right)}
$$

Where:

$B=$ Bray-Curtis dissimilarity

$S=$ total species number in land use 1 and land use 2

$n_{1}=$ number of individual species $i$ in land use 1

$n_{2}=$ number of individual species $i$ in land use 2

Shannon-Wiener diversity index $\left(\mathrm{H}^{\prime}\right)$ is one of popular index that use in ecological studies. It represents how species heterogeneity of a site that incorporates species richness and evenness. The value of Shannon-Wiener index varied between 0-3.5, rarely surpass 4.5. 


$$
H^{\prime}=-\sum p i(\ln p i)
$$

Where, $p i=$ proportion of individual number of each species to total species $i$

The value of $\mathrm{H}^{\prime}$ represents species heterogeneity that classified into: low $\left(\mathrm{H}^{\prime}<1.5\right)$, medium $(1.5-3.5)$ and high $\left(\mathrm{H}^{\prime}>3.5\right)$.

\subsubsection{Carbon stock analysis}

Aboveground tree biomass of general species was calculated using allometric equation developed by Chave et al (2005) for humid/moist topical forest stand with precipitation between $1500 \mathrm{~mm}$ -

4000mm/year:

$$
\begin{aligned}
& \text { Above - Ground Biomass } \text {.est }(\mathrm{kg}) \\
& \qquad \quad \rho * \operatorname{esp}\left(-1.499+2.148 \ln (D)+0.207(\ln (D))^{2}-0.0281(\ln (D))^{3}\right)
\end{aligned}
$$

However, for specific species we use allometric equations developed by various researchers compiled in Hairiah et al. (2011) (Table 1).

Table 1. Allometric equations for biomass estimation of specific species

\begin{tabular}{lll}
\hline Tree species & Allometric Equation & Source \\
\hline Coffee regularly pruned & (AGB)est $=0.281 \mathrm{D}^{2.06}$ & Arifin 2001 \\
Cacao & (AGB)est $=0.1208 \mathrm{D}^{1.98}$ & Yuliasmara 2008 \\
Oil palm & (AGB)est $=0.0976 \mathrm{H}+0.0706$ & ICRAF 2009 \\
Palm & (AGB)est $=\exp \{-2.134+2.530 \times \ln (\mathrm{D})\}$ & Brown 1997 \\
Palm & (AGB)est $=4.5+7.7 \times \mathrm{H}$ & Frangi and Lugo 1985 \\
Bamboo & (AGB)est $=0.131 \mathrm{D}^{2.28}$ & Priyadarsini 2000 \\
Banana & (AGB)est $=0.030 \mathrm{D}^{2.13}$ & Arifin 2001 \\
\hline
\end{tabular}

Note: $(A G B)$ est $=$ estimation aboveground tree biomass, $\mathrm{kg} / \mathrm{tree} ; \mathrm{D}=\mathrm{DBH}$, diameter at breast height, $\mathrm{cm} ; \mathrm{H}=$ tree height, $\mathrm{m} ; \rho$ $=$ Wood density, $\mathrm{gcm}^{-3}$ (available from: http://db.worldagroforestry.org/wd).

\section{Results}

\subsection{Land use characteristics}

Amount total of 71 plots from 22 land cover system had been surveyed across of the three districts in East Kalimantan (Table 2).

Table 2. Number of sampled plot in each land cover systems of Berau, Kutai Timur and Pasir District, East Kalimantan in 2015-2016

\begin{tabular}{llllll}
\hline \multirow{2}{*}{ No } & Land cover & \multicolumn{3}{c}{ District } & \multirow{2}{*}{ Total } \\
\cline { 3 - 5 } & & Berau & Kutai Timur & Pasir & \\
\hline 1 & Undisturbed mangrove & 2 & 3 & 2 & 7 \\
\hline 2 & Disturbed mangrove & 1 & & 3 & 4 \\
\hline 3 & Undisturbed forest & 2 & & 2 & 4 \\
\hline 4 & Logged-over forest high density & 3 & & 1 & 4 \\
\hline 5 & Logged-over forest low density & & 2 & 1 & 3 \\
\hline 6 & Logged-over swamp forest & & & 2 & 2 \\
\hline 7 & Fruit-based agroforest & 11 & 4 & 2 & 17 \\
\end{tabular}




\begin{tabular}{|c|c|c|c|c|c|}
\hline \multirow[t]{2}{*}{ No } & \multirow[t]{2}{*}{ Land cover } & \multicolumn{3}{|c|}{ District } & \multirow[t]{2}{*}{ Total } \\
\hline & & Berau & Kutai Timur & Pasir & \\
\hline 1 & Undisturbed mangrove & 2 & 3 & 2 & 7 \\
\hline 8 & Coconut monoculture & & 3 & & 3 \\
\hline 9 & Coconut agroforest & 1 & & & 1 \\
\hline 10 & Rubber monoculture & & 3 & 1 & 4 \\
\hline 11 & Rubber agroforest & & & 1 & 1 \\
\hline 12 & Pepper monoculture & & & & \\
\hline 13 & Pepper agroforest & 2 & 1 & & 2 \\
\hline 14 & Cacao agroforest & & & & \\
\hline 15 & Citrus monoculture & & 4 & & 4 \\
\hline 16 & Teak agroforest & 1 & 1 & & 2 \\
\hline 17 & Teak monoculture & 1 & & 1 & 2 \\
\hline 18 & Home garden & & & 1 & 1 \\
\hline 19 & Sengon monoculture & & & 1 & 1 \\
\hline 20 & Acacia monoculture & & & 1 & 1 \\
\hline 21 & Gmelina plantation & 3 & 2 & 1 & 1 \\
\hline \multirow[t]{2}{*}{22} & Gaharu agroforest & 1 & & & 1 \\
\hline & Total & 28 & 26 & 17 & 71 \\
\hline
\end{tabular}

\subsubsection{Undisturbed mangrove}

Three plots of undisturbed mangrove were set up in Sangkima Village, Sangatta Selatan, Kutai Timur district with coordinate location at $0.399848^{\circ}$ and $117.561372^{\circ}, 0.405800^{\circ}$ and $117.557013^{\circ}$, and $0.404474^{\circ}$ and $117.556688^{\circ}$. Plots were located in estuarine area with mud as dominant substrate. Rhizophora sp. is the most dominant species, while Sonneratia sp. also found. Tree $>10 \mathrm{~cm}$ is very common, a few sapling and pole and understorey species is absent.

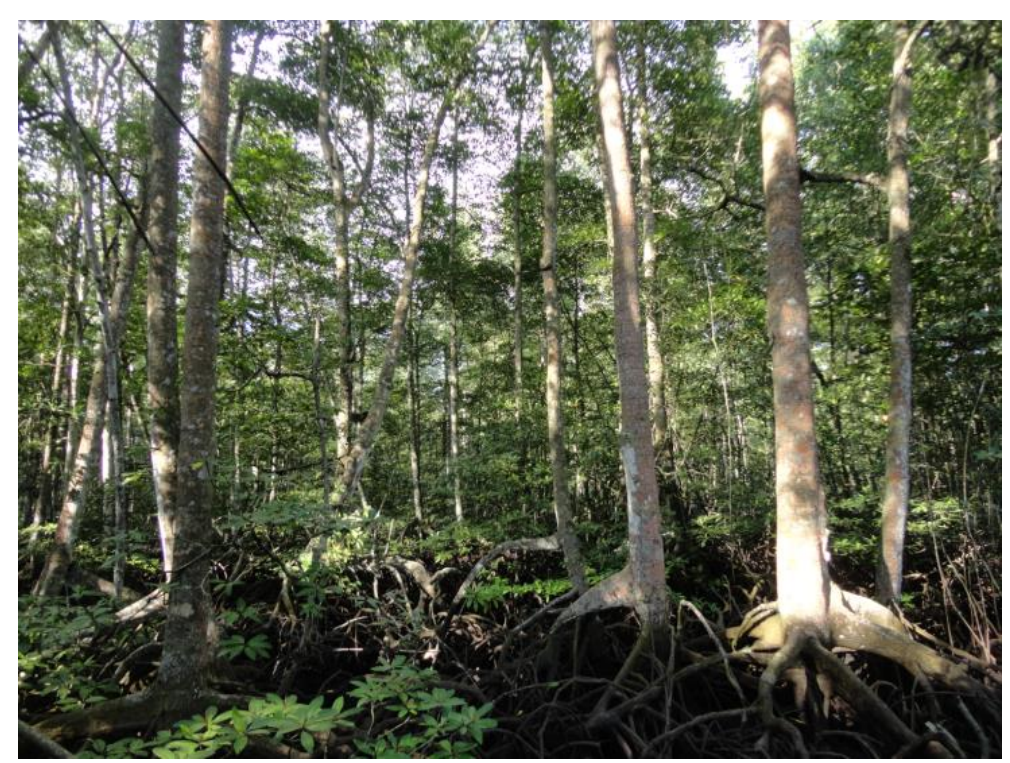

Figure 5. Undisturbed mangrove in Kutai Timur 
Two plots of undisturbed mangrove set up in Pondong Baru Village, Kuaro, Pasir District at $1.79848^{\circ}$ and $116.22731^{\circ},-1.80072^{\circ}$ and $116.22688^{\circ}$. Rhizophora sp. is the common species, while Xylocarpus sp. also found. Tree $>10 \mathrm{~cm}$ is very common, while seedling found in open canopy area. Land conversion to fish and shrimp pond is widely occurred by migrants people, mostly from Sulawesi. Undisturbed mangrove mostly found at coastline or river banks at about 100 meters wide, while in the middle area mostly had been cleared off, an access road has built to connect between the area and village.

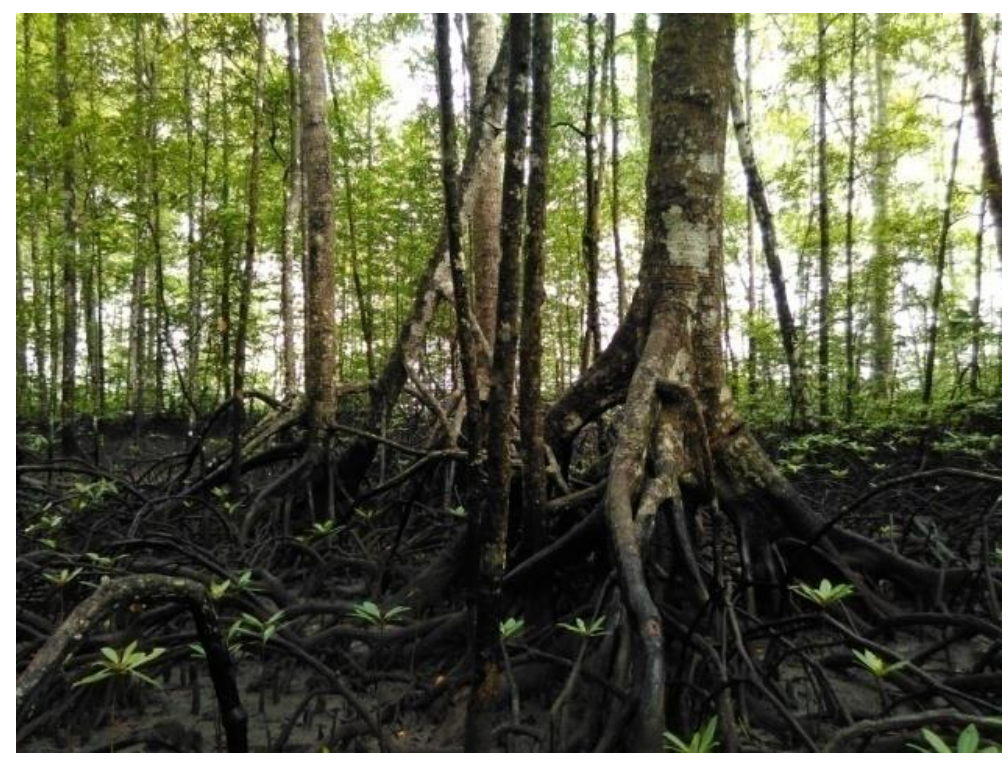

Figure 6. Undisturbed mangrove in Pasir

Two plots of undisturbed mangrove set up in Teluk Sulaiman Village, Biduk-biduk, Berau District at $1.16056^{\circ}, 118.75881^{\circ}$ and $1.16152^{\circ}, 118.76328^{\circ}$. Mangrove forest covering approximately 47.941 ha or about 3\% of total land area of Berau District. Mangrove forest spread over the coastal area and small islands. Undisturbed mangrove is quite extensive both in Berau (Figure 7). At the coastline, mangrove species dominated by Rhizophora and Sonneratia species, depends on substrate type. There are many trees $>10 \mathrm{~cm}$ diameter as well as seedlings. Rhizophora apiculata dominated the muddy soil area, while Sonneratia alba and Rhizophora apiculata on the mixed of sand and mud soil.
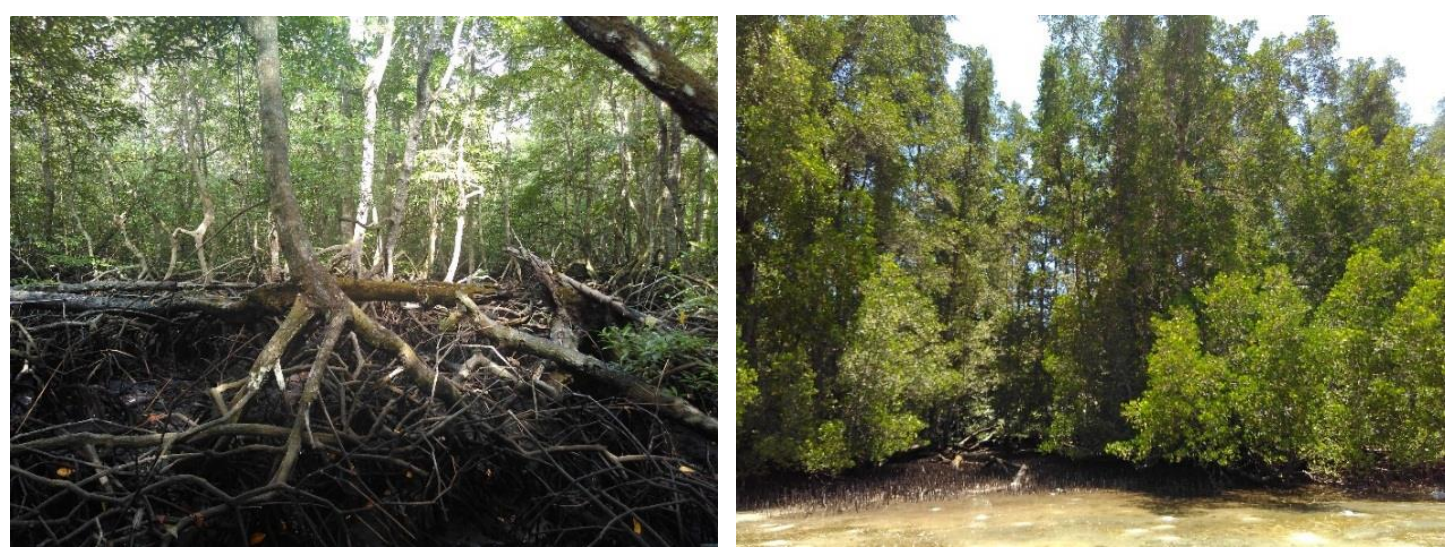

Figure 7. Undisturbed mangrove in Berau 


\subsubsection{Disturbed mangrove}

Three plots of disturbed mangrove located at Sangkima Village, Sangatta Selatan, Kutai Timur at $0.397062^{\circ}$ and $117.563628^{\circ}, 0.393145^{\circ}$ and $117.564875^{\circ}, 0.388656^{\circ}$ and $117.564193^{\circ}$. Conversion to ponds, firewood or building materials is the common reason causes mangrove degradation, particularly where located near the settlement. Fewer large tree $>10 \mathrm{~cm}$ diameter available in disturbed mangrove. The most dominant species in disturbed mangrove of the area are Cerios tagal and Lumnitzera littorea.

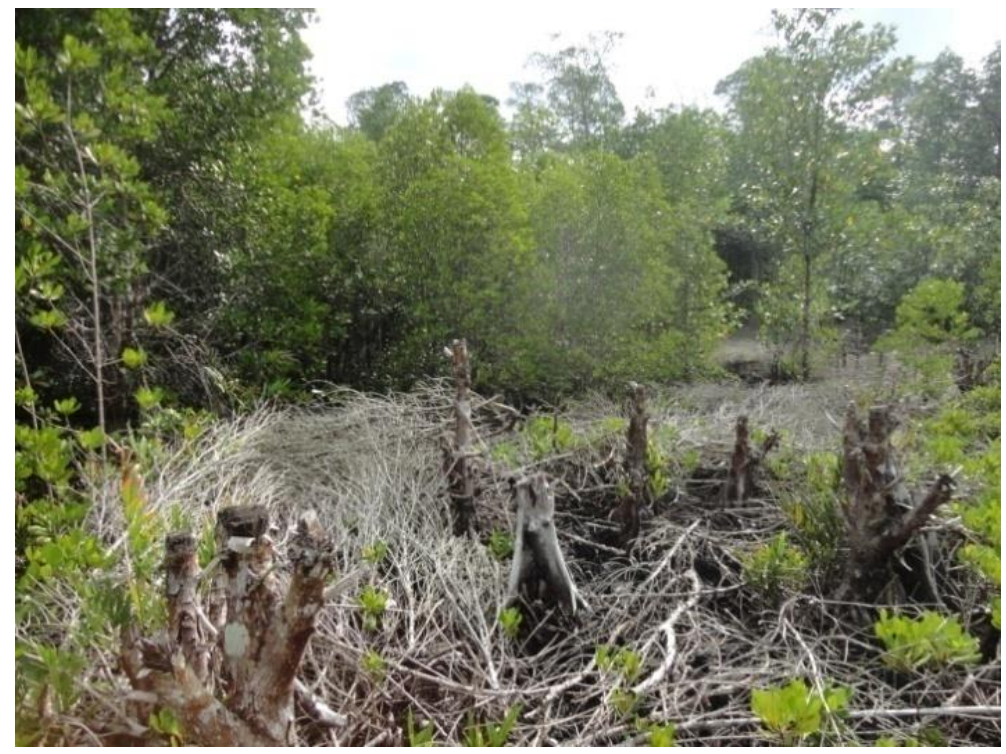

Figure 8. Disturbed mangrove

A plot of disturbed mangrove was set up in sandy soil substrate of Teluk Sulaiman Village, Bidukbiduk, Berau at $1.20132^{\circ}$ and $118.76485^{\circ}$. Sonneratia alba is dominant species. There is no seedlings, sapling and pole in the sampled plot although the mature tree are remain, however the tree stand has been old, with this condition the mangrove on the sampled plot is threatened due to no regeneration (Figure 9).

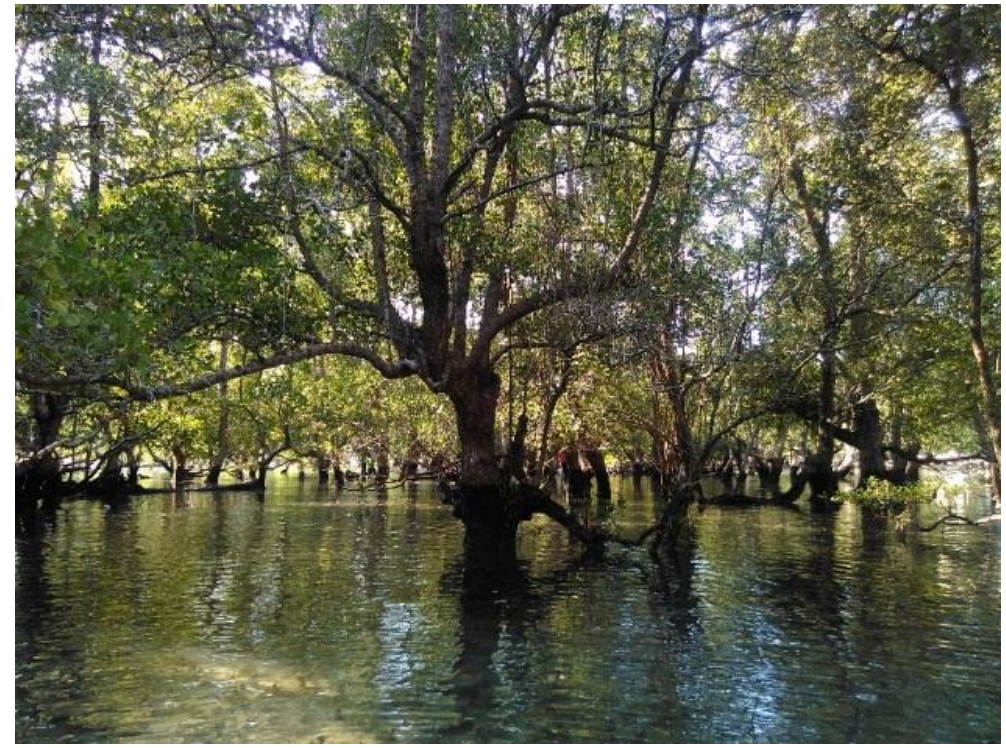

Figure 9. Disturbed mangrove in Berau 


\subsubsection{Undisturbed forest}

Two plots of undisturbed forest set up in Muluy Hamlet, Long Sayo Village, Muara Komam, Pasir at $-1.447469^{\circ}$ and $115.920857^{\circ},-1.434324^{\circ}$ and $115.974248^{\circ}$ where located in Gunung Lumut protected forest. The topography of the area mostly at sloping ground with altitude around 200-400 $\mathrm{m}$ asl. Many trees $>30 \mathrm{~cm}$ diameter are available in the area (Figure 10).

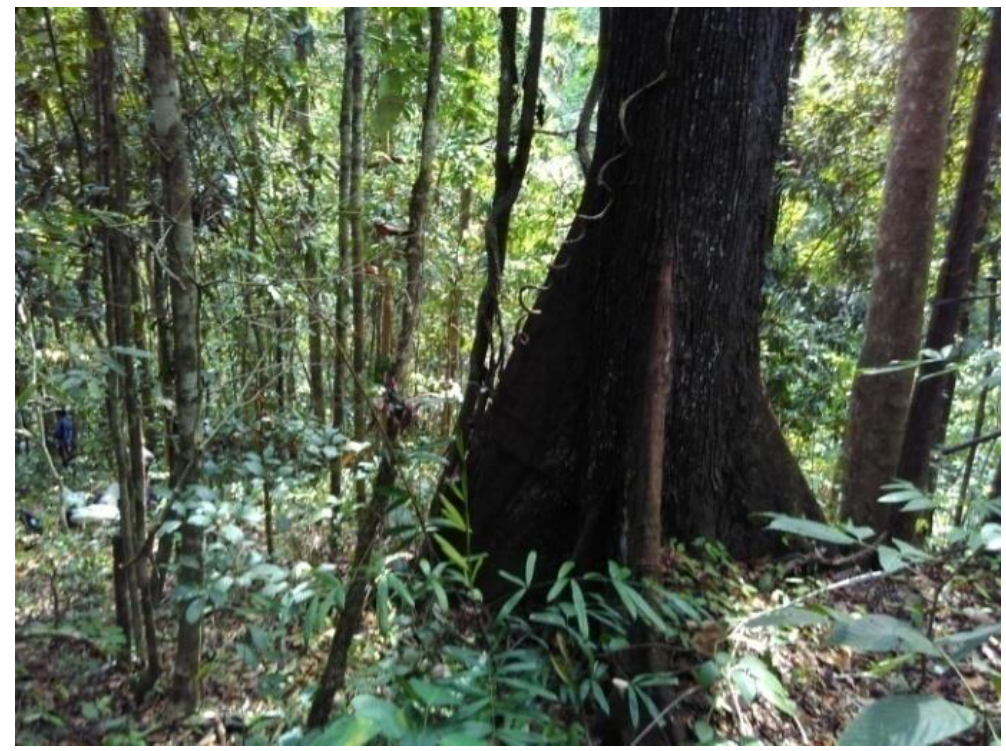

Figure 10. Undisturbed forest in Gunung Lumut protected forest of Pasir

Two plots of undisturbed forest set up in Sungai Lesan Protected Forest (HLSL) at $1.61102^{\circ}$, $117.16323^{\circ}$ and $1.61112^{\circ}, 117.16665^{\circ}$. All of growth stage available in the forest, understory rarely found, but quite plenty of seedling and sapling (Figure 11).

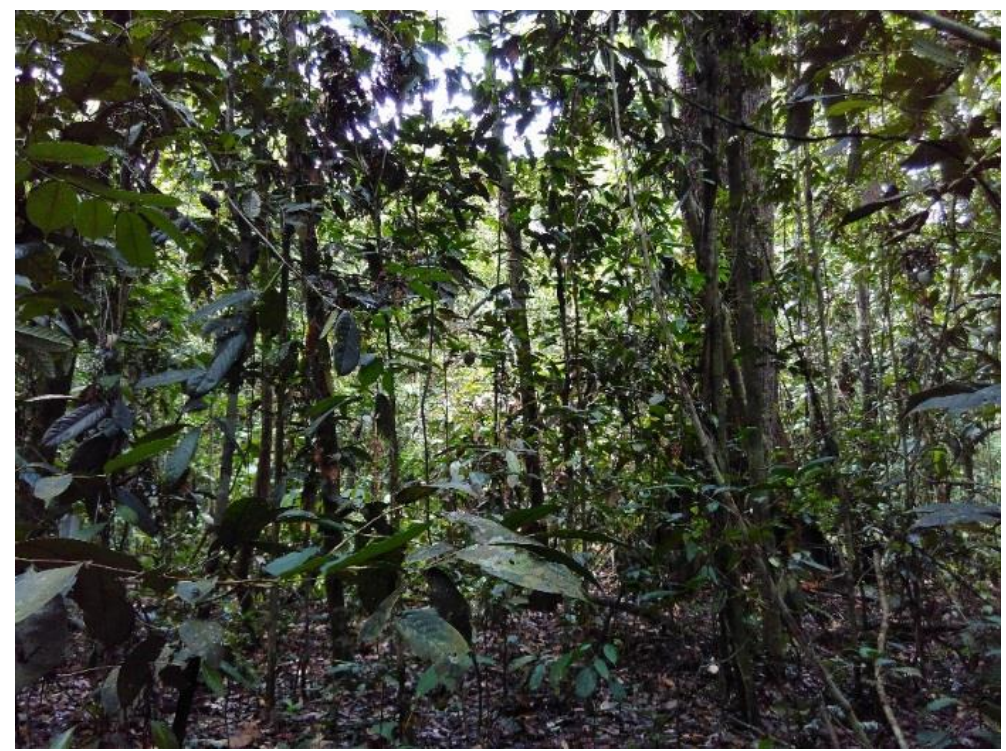

Figure 11. Undisturbed forest of Sungai Lesan protected forest, Berau

HLSL is protected forest located at Kelay and covering four villages with total area 11,342.61 ha at elevation between 40 to 430 meters above sea level. Tree composition dominated by Dipterocarpaceae family. 


\subsubsection{Logged-over forest high density}

A plot of logged-over forest high density surveyed at Petangis Village, Batu Engau, Pasir at $2.062294^{\circ}$ and $116.095009^{\circ}$ where located in the former coal mining. Currently the area is being established as recreational area and part of Taman Hutan Raya Lati Petangis. A block of remnant forest (Figure 12) found between Acacia plantation for reclaim degraded land after mining activities.

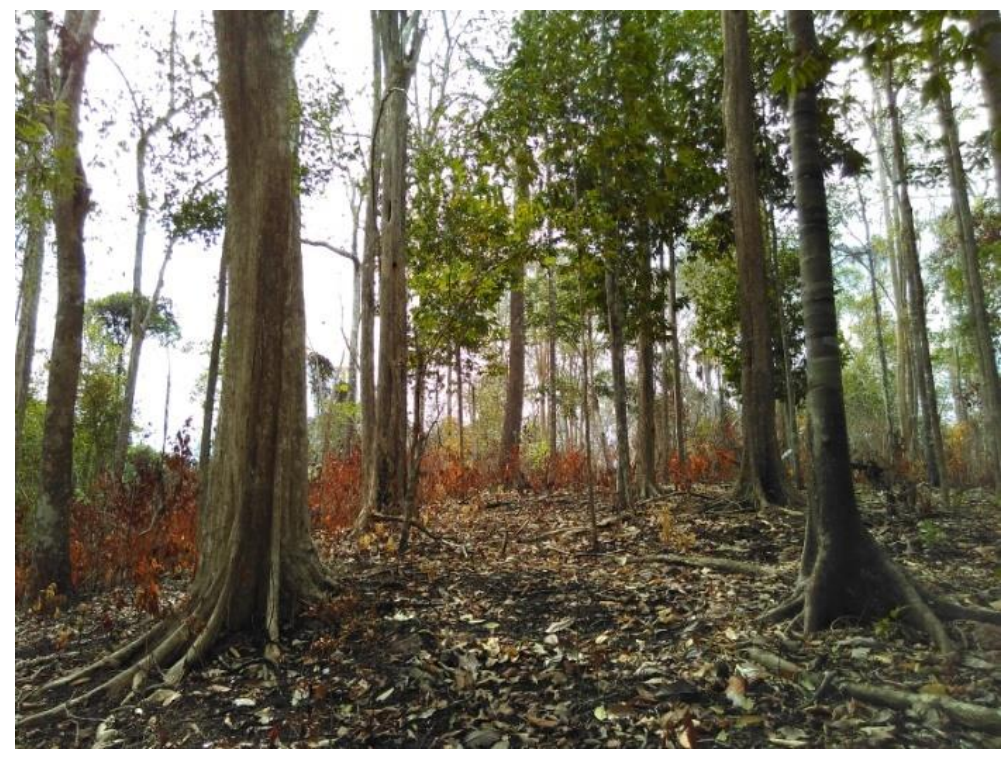

Figure 12. Logged-over forest high density

Three plots of logged-over forest were set up in Berau, two plots in Hutan Lindung Sungai Lesan at $1.65344^{\circ}, 117.08634^{\circ}$ and $1.65240^{\circ}, 117.08749^{\circ}$ and one plot in Hutan Lindung Dumaring at $1.39003^{\circ}$ and $118.09079^{\circ}$. Visually, species composition in logged-over forest of Sungai Lesan is similar to undisturbed forest, but lower density of large trees. Logging activity and decaying old tree creating the gap and causes amount of seedling and sapling regenerated in. Logging activity at HLSL was occurred in the past, but forest recovery is in good progress. Land conversion is the main threat of Hutan Lindung Dumaring forest, particularly in the border area of protected forest. Canopy closure in the area is medium, while the understory is composed by seedlings, saplings and shrub species (Figure $13)$.
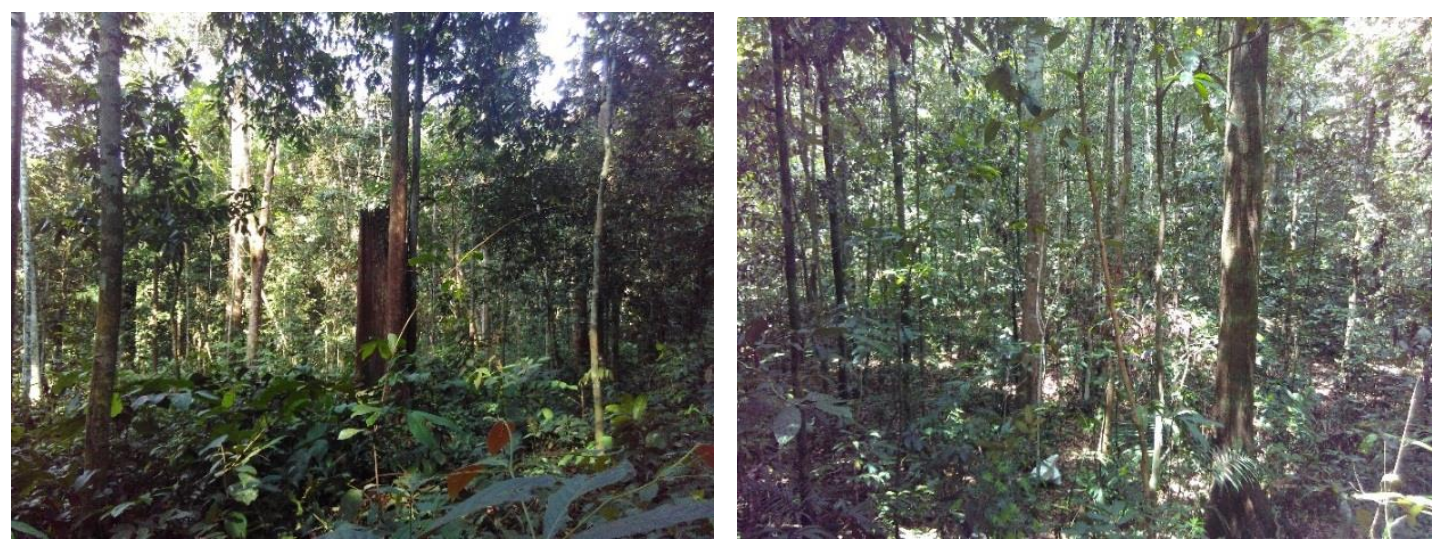

Figure 13. Logged-over forest high density in Hutan Lindung Sungai Lesan (left) and Hutan Lindung Dumaring (right), Berau 


\subsubsection{Logged-over forest low density}

Two plots of logged-over forest low density set up in Miau Baru village, Kutai Timur at $0.397062^{\circ}$ and $117.563628^{\circ}, 0.393145^{\circ}$ and $117.564875^{\circ}$. Cleared land was done by Dayak Kayan since 1978 to grow crop, mostly rice using slash and burn method. Secondary forest from medium to large tree diameter and shrub available in the area, depend on fallow period left by land manager. Pioneer species such as Vitex pubescens commonly grow in recently burnt land (Figure 14).

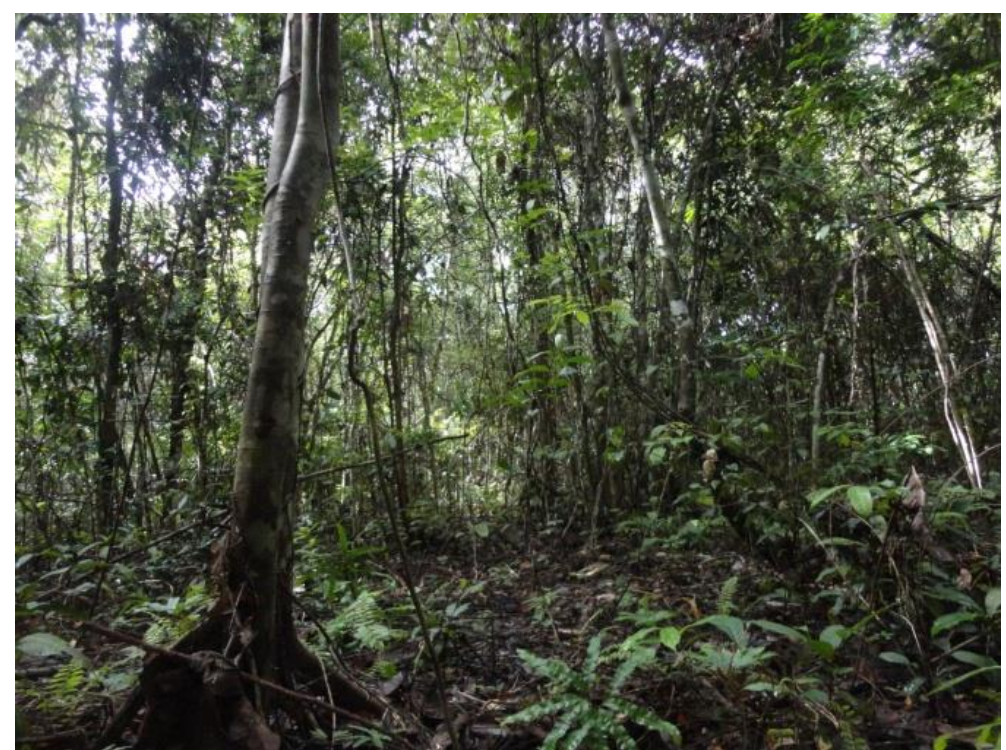

Figure 14. Logged-over forest low density in Kutai Timur

A plot of logged-over forest low density set up in Jone Village, Tanah Grogot, Pasir at $-1.878129^{\circ}$ and116.203313 ${ }^{\circ}$. Abandoned land as shrub very common in Tanah Grogot (Figure 14).

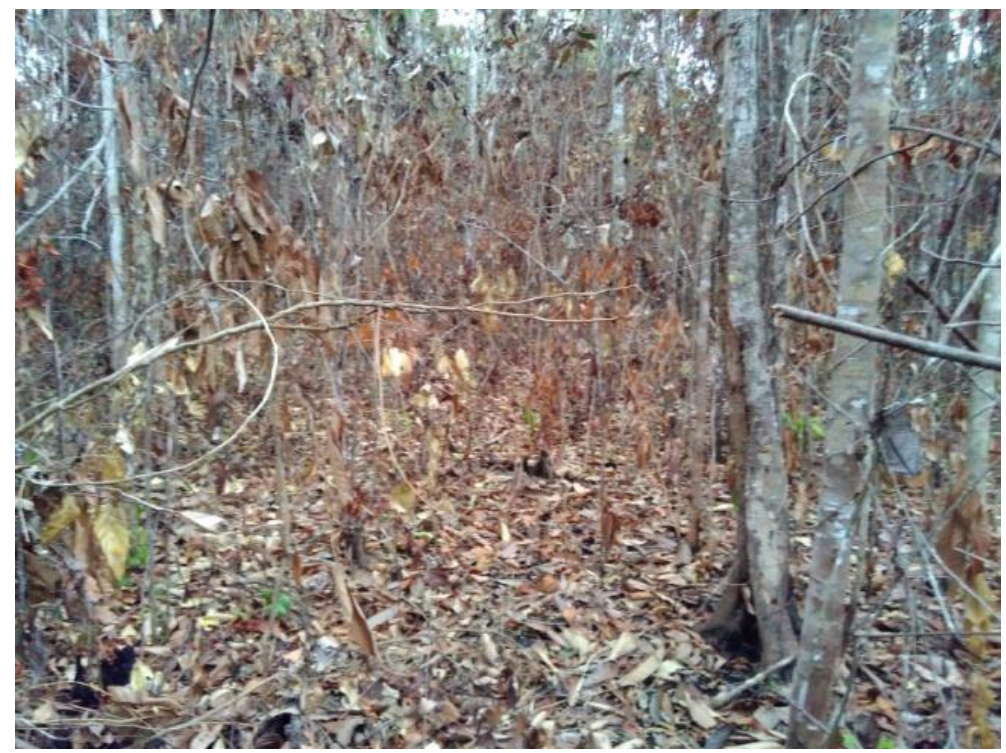

Figure 15. Logged-over forest low density in Pasir.

\subsubsection{Logged-over swamp forest}

Two plots of logged-over swamp forest were set up in Jone Village at $-1.90005^{\circ}$ and $116.25122^{\circ}$ and Rantau Panjang Village, Tanah Grogot, Pasir. Mixed tree species with shrubs and lianas commonly found, but gelam (Melaleuca sp.) found in Rantau Panjang (Figure 16). Local people collect its wood 
and bark for building materials. Swamp forest in both of Jone and Rantau Panjang are inundated during rainy season.
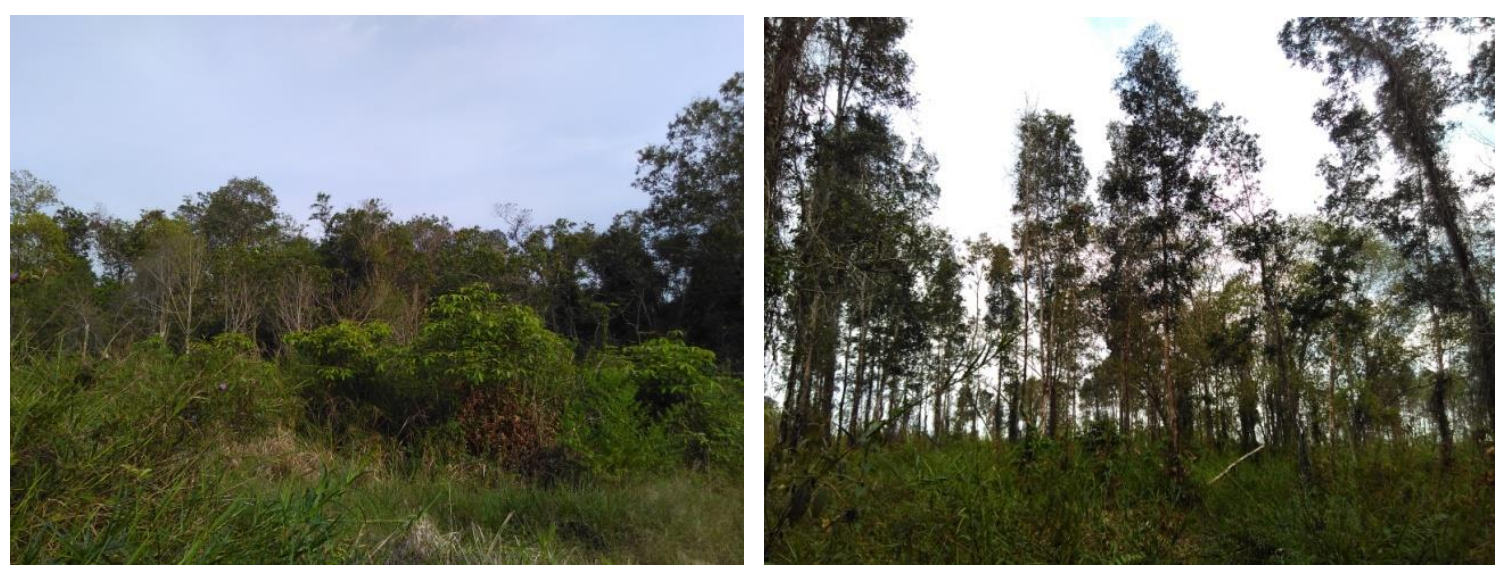

Figure 16. Heterogenous logged-over swamp forest in Jone (left), homogenous logged-over swamp forest in Rantau Panjang (right), Pasir

\subsubsection{Fruit-based agroforestri}

Two plots were set up in Miau Baru village, Kongbeng, Kutai Timur at $1.192935^{\circ}$ and $116.940951^{\circ}$, $1.193625^{\circ}$ and $116.941848^{\circ}$ and two plots in Sangatta, Kutai Timur at $0.487950^{\circ}$ and $117.489270^{\circ}$, $0.467312^{\circ}$ and $117.481275^{\circ}$. A fruit-based agroforestry system integrated with livestock herding area is found in Miau Baru Village, particularly along the river. Lansium domesticum as main fruit trees mixed with other wild fruit trees of Artocarpus sp. and Syzigium sp. without management systems.

The fruit-based agroforest where close to the settlement consist of mango, cacao, coconut, rambutan and durian used for daily utilization (Figure 17).
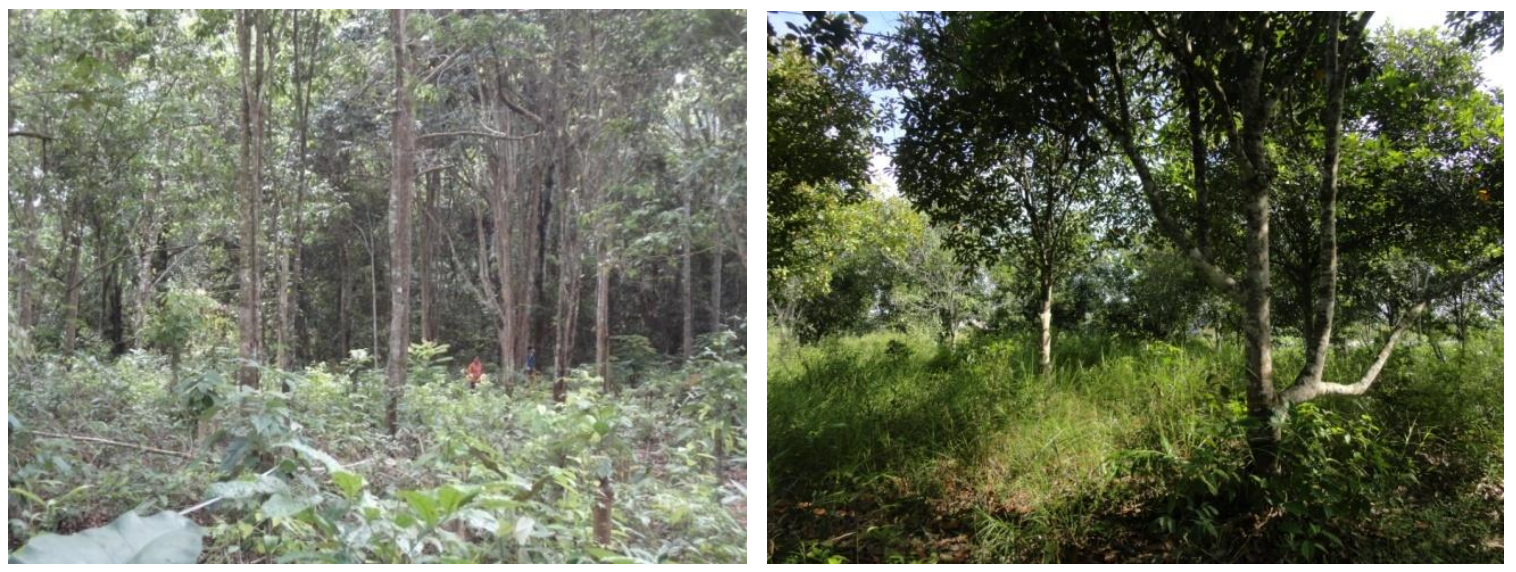

Figure 17. Fruit-based agroforestry in Miau Baru (left), and rambutan plantation in Sangatta (right)

An intensive of 15 years durian plantation established by private sector found in Mulyo Sari hamlet, Padang Pangrapat Village, Tanah Grogot, Pasir at $-1.84802^{\circ}$ and $116.24375^{\circ}$. The durian trees were planted in $10 \mathrm{~m}$ distance and pruned (Figure 18). Another type of fruit based agroforest plot was set up in Kasungai Village, Batu Sopang, Pasir at $-1.803542^{\circ}$ and $115.916174^{\circ}$. A various type of fruit trees planted within the area consists of rambutan, coconut, jackfruit, durian, Lansium domesticum etc. Low management implemented characterized with flourish of understorey (Figure 18). Rubber is very common in this area while fruit-based agroforest is rarely found in large area. People tend to plant fruit trees around the settlement for daily consumption. 


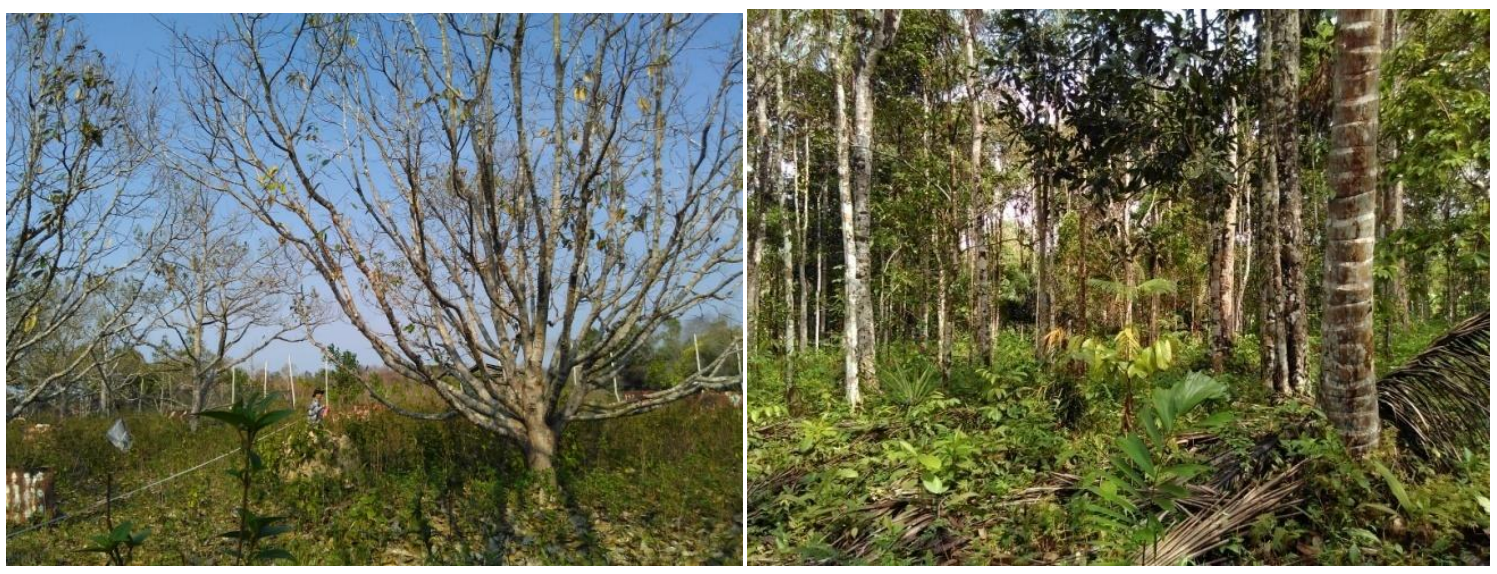

Figure 18. Durian plantation (left), fruit-based agroforest (right) in Pasir


Figure 19. Various types of fruit-base agroforestry in Berau 
In Berau, several types of mix garden are established based on environment and sosio-economic factor (Figure 19). Fruit-based agroforest found in Lesan Dayak Village, Kelay. Langsat (Lansium domesticum) and Caryota are dominant species with coffee and other species intercropped in. Fruitbased agroforest in Gunung Tabur, where cultivated by migrant people from Java and South Sulawesi used rambutan as main commodity such as in Birang village. In Teluk Bayur Dayak tribe and migrant people from Melayu, Java and South Sulawesi cultivate cacao inside the systems. In Talisayan home garden of local people, consists of areca nut, candle nut, durian and langsat.

\subsubsection{Coconut monoculture}

Three plots of coconut monoculture set up in Sangkima Village, Sangatta Selatan, Kutai Timur at $0.397479^{\circ}$ and $117.564020^{\circ}, 0.392691^{\circ}$ and $117.565629^{\circ}, 0.394349^{\circ}$ and $117.565425^{\circ}$. Migrant people from South Sulawesi live in the area and plant coconut in $8 \times 10 \mathrm{~m}$ distance around the home yard for additional income since they settle at the location since about 40 years ago (Figure 20).

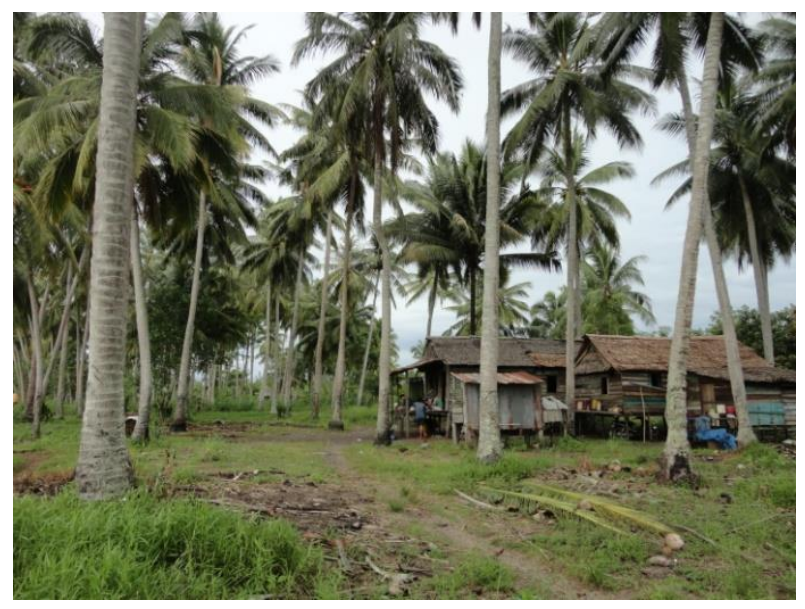

Figure 20. Coconut monoculture in Sangatta, Kutai Timur

\subsubsection{Coconut agroforest}

Coconut plantation, both monoculture and agroforest, mostly concentrated on coastal region. Monoculture system established at near shore while agroforest system sometimes established at higher elevation in mixed garden as intercrop. A plot of coconut agroforest was set up in Teluk Sulaiman village, Biduk-Biduk, Berau at $1.18885^{\circ}$ and $118.76799^{\circ}$. The plantation has been established since 1970, some coconut stand has been replaced by new trees in 10 x 10 meters spacing. Some fruit trees found among the coconut stand, such as mango, star fruit and jackfruit (Figure 21). 


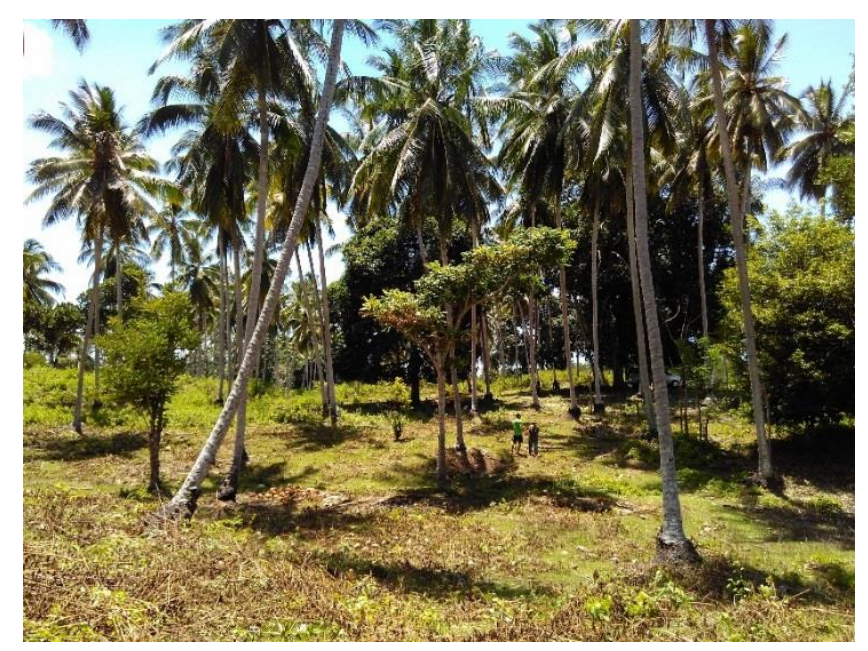

Figure 21. Coconut agroforest in Berau

\subsubsection{Rubber monoculture}

Three plots of rubber monoculture were set up in Miau Baru Village, Kongbeng, Kutai Timur at $1.294320^{\circ}$ and $117.070321^{\circ}, 1.208958^{\circ}$ and $116.966148^{\circ}, 1.194603^{\circ}$ and $116.945928^{\circ}$ that covered of different plantation age: 3-4 years, over 10 years and old rubber monoculture. Young rubber monoculture planted in 5 meters distance, semi intensive management is implemented in the system. Middle aged rubber monoculture applied 6 or 7 meters distance. The canopy cover is not tight so the farmer plant pineapple as intercropping. At old rubber monoculture cacao planted as intercrop, some understorey seedling has presence, another pioneer species also found such as Macaranga triloba (Figure 20).
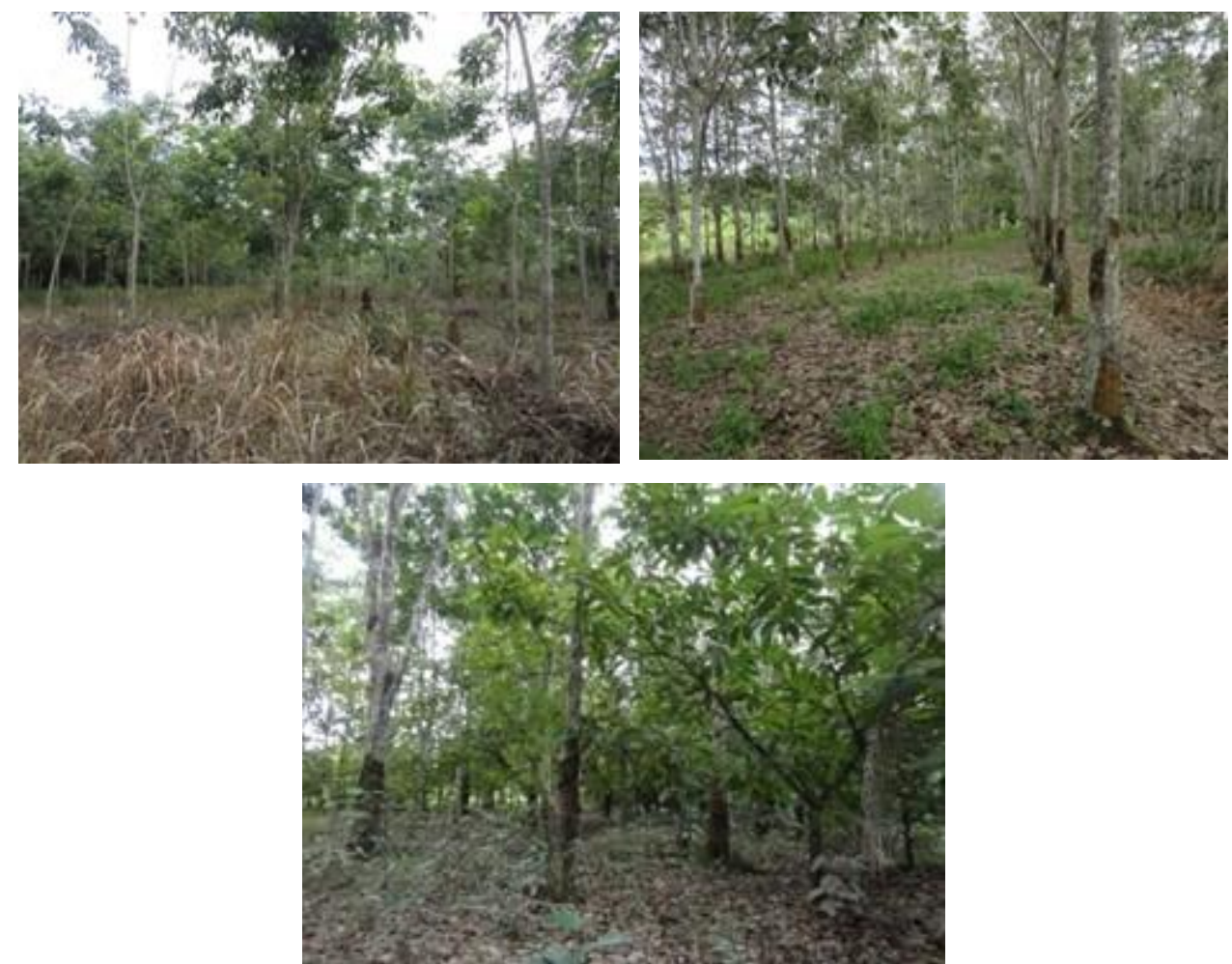

Figure 22. Rubber monoculture in Kutai Timur, Young rubber 3 - 4 years (left), $>10$ years (center), old rubber (right). 
A plot of 8 years orubber monoculture was set up in Mulyo Sari, Padang Pangrapat, Tanah Grogot, Pasir at $1.84802^{\circ}$ and $116.24375^{\circ}$ (Figure 23).

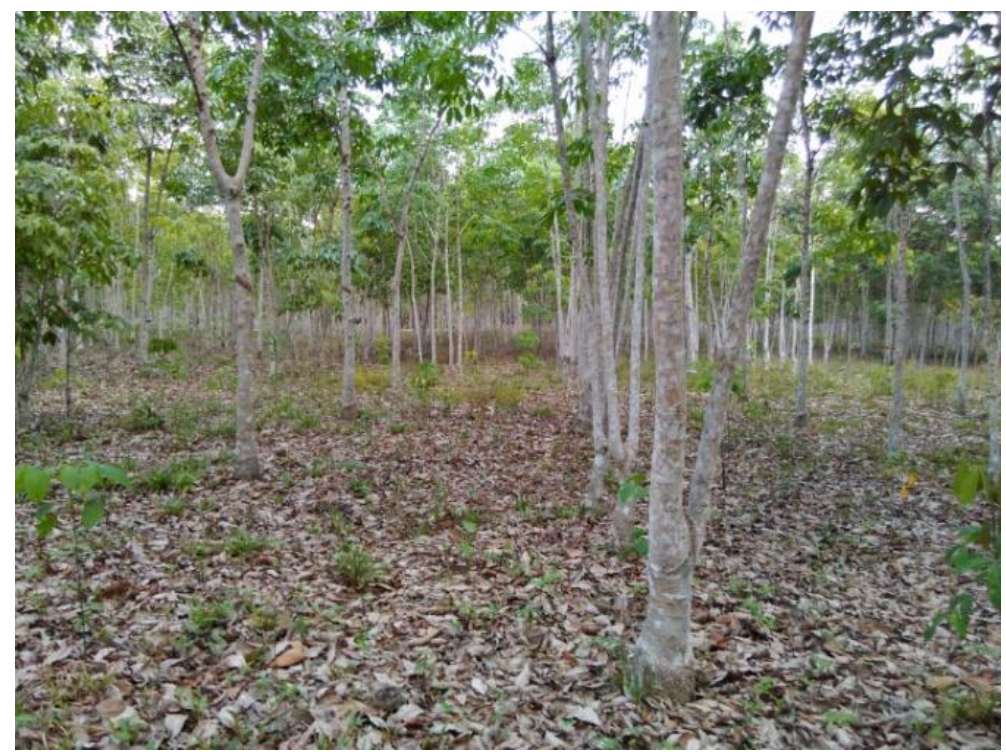

Figure 23. Rubber monoculture in Pasir

\subsubsection{Rubber agroforest}

A plot of old rubber agroforest established in 1985 was set up in Pasir Belengkong Village, Pasir Belengkong, Pasir at $-2.001627^{\circ}$ and $116.210386^{\circ}$. Semi intensive management implemented characterized by flourish of understorey and many tree seedlings, the canopy cover is medium to high. The trees are planted in random pattern. Mostly tree seedling or sapling are cut off, only fruit trees that can be utilized or which can be sold are allowed to grow, such as jack fruit and lai (Durio kutejensis) (Figure 24).

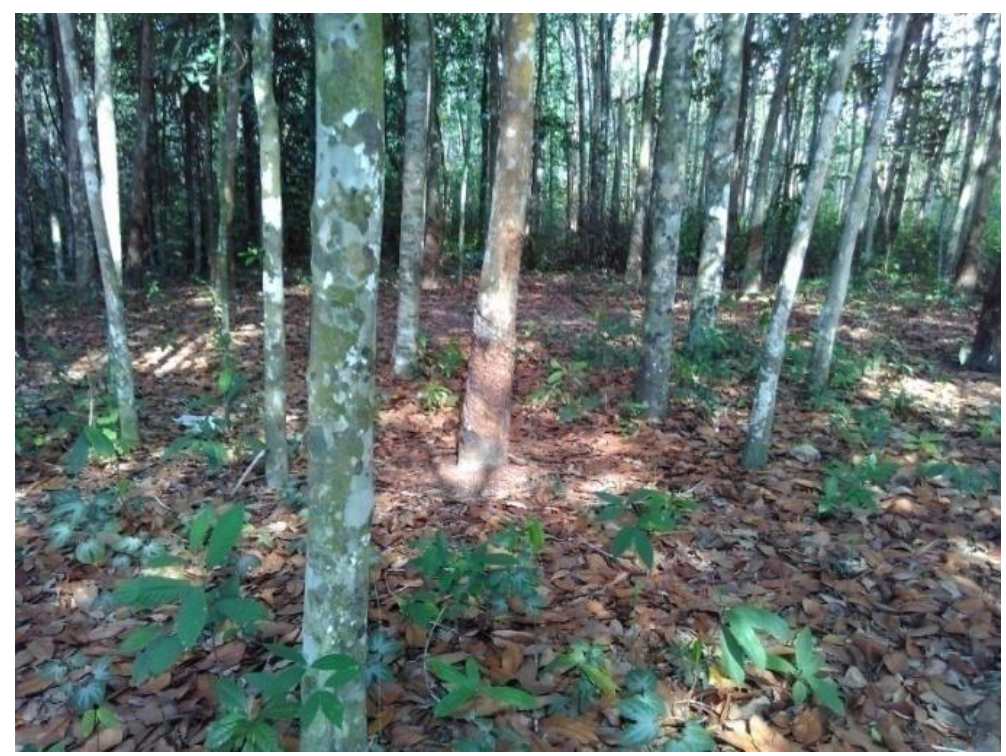

Figure 24. Rubber agroforest in Pasir 


\subsubsection{Pepper monoculture}

A plot of pepper monoculture set up in Miau Baru Village, Kongbeng, Kutai Timur at $1.293984^{\circ}$ and $117.071173^{\circ}$. Paper planted at $2 \mathrm{~m}$ distance with wood block of ulin and Gliciridia sepium as shading trees (Figure 25).

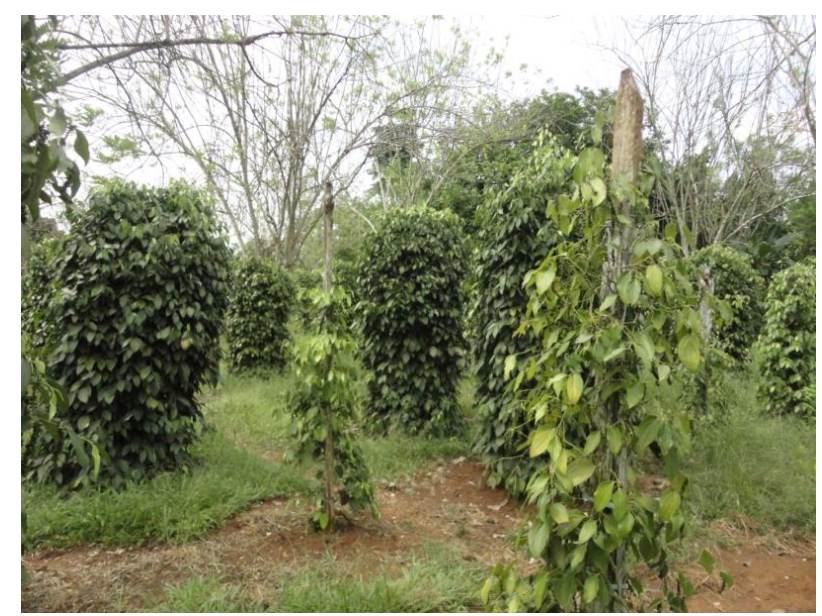

Figure 25. Pepper monoculture in Kutai Timur

\subsubsection{Pepper agroforest}

Basically, there are two types of pepper systems in East Kalimantan, they are: 1) pepper with Gliricidia sepium as stake, and 2) pepper with ulin wood block (Eusideroxylon zwageri) as stake at $1.5 \times 1.5$ meters or $2 \times 2$ meters spacing. Farmer plant pepper with monoculture system or mixed with another species, mostly with Gliricidia sepium, Leucaena leucocephala or Moringa oleifera as shading trees for young pepper. Pruning for shading tree implemented depends on climate, usually conducted at rainy season where sunlight penetration is less. Weed management using herbicide to control weed population and fertilize regularly done. A plot of pepper agroforest set up in Birang Village, Gunung Tabur at $2.20956^{\circ}$ and $117.46076^{\circ}$ and a plot in Dumaring Village, Talisayan, Berau at $1.57425^{\circ}$ and $118.20133^{\circ}$ (Figure 26).
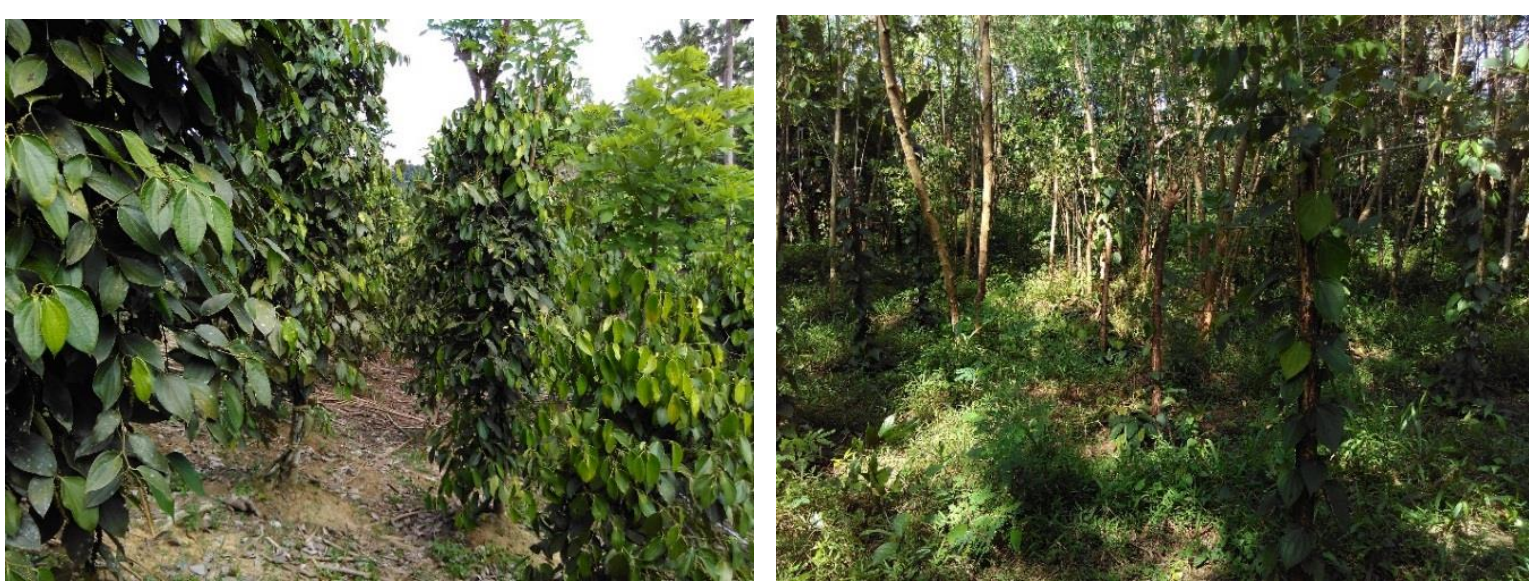

Figure 26. Pepper plantation (left: wood stake; right: Gmelina stake) in Berau 


\subsubsection{Cacao agroforest}

Three plots of cacao agroforest set up in Miau Baru Village, Kongbeng, Kutai Timur at $1.208735^{\circ}$ and $116.954033^{\circ}, 1.190844^{\circ}$ and $116.940618^{\circ}, 1.191328^{\circ}$ and $116.941833^{\circ}$. Cacao was planted at $3 \mathrm{~m}$ distance and was pruned at about 1 to 2 meters height. Some fruit trees such as Nephelium lappaceum, Durio zibethinus, Mangifera indica, Artocarpus champeden or Dimocarpus longan and wild species such as Piper aduncum and Vitex pubescens found in the system (Figure 27).

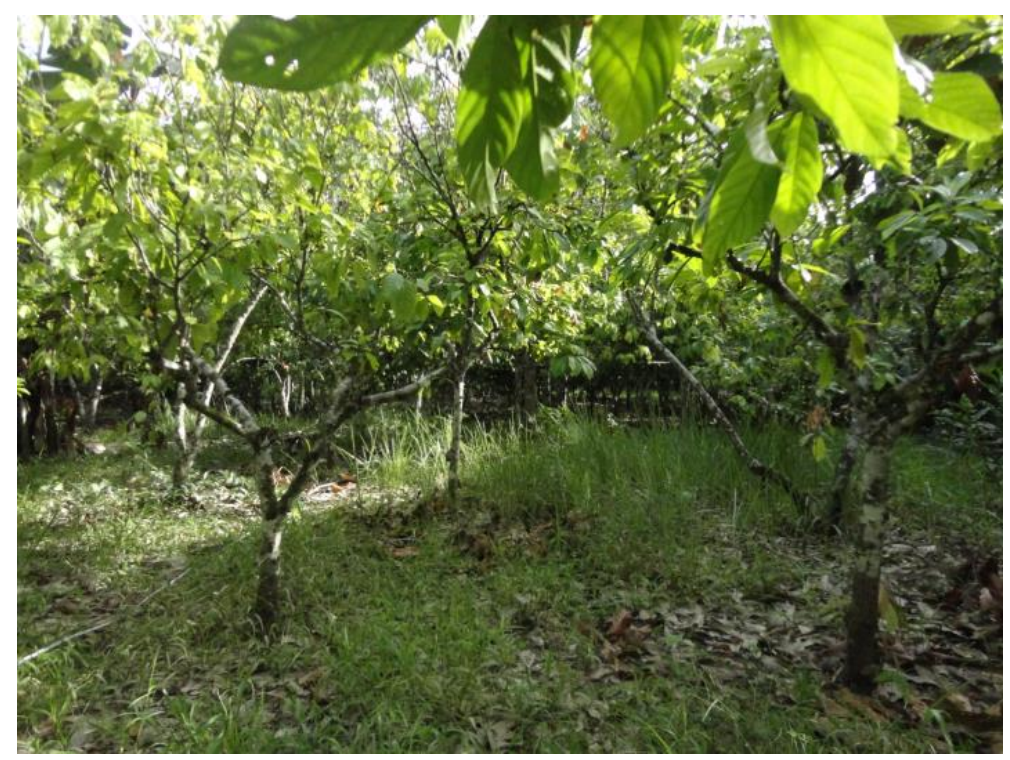

Figure 27. Cacao agroforest in Kutai Timur

\subsubsection{Citrus monoculture}

A plot of citrus monoculture set up in Miau Baru Village, Kongbeng, Kutai Timur at $1.191179^{\circ}$ and $116.940165^{\circ}$. Citrus planted at about 4 meters distance (Figure 28).

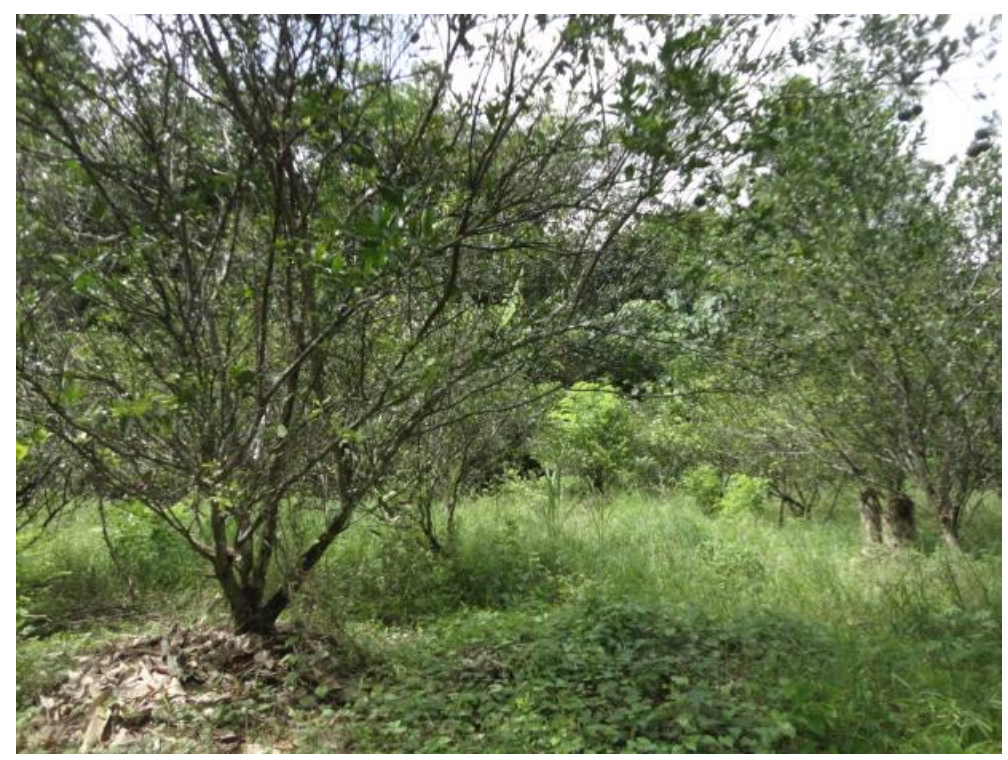

Figure 28. Citrus monoculture in Kutai Timur 


\subsubsection{Teak agroforest}

A plot of teak agroforest was set up in Miau Baru Village, Kongbeng, Kutai Timur at $1.193214^{\circ}$ and $116.941215^{\circ}$ (Figure 29).

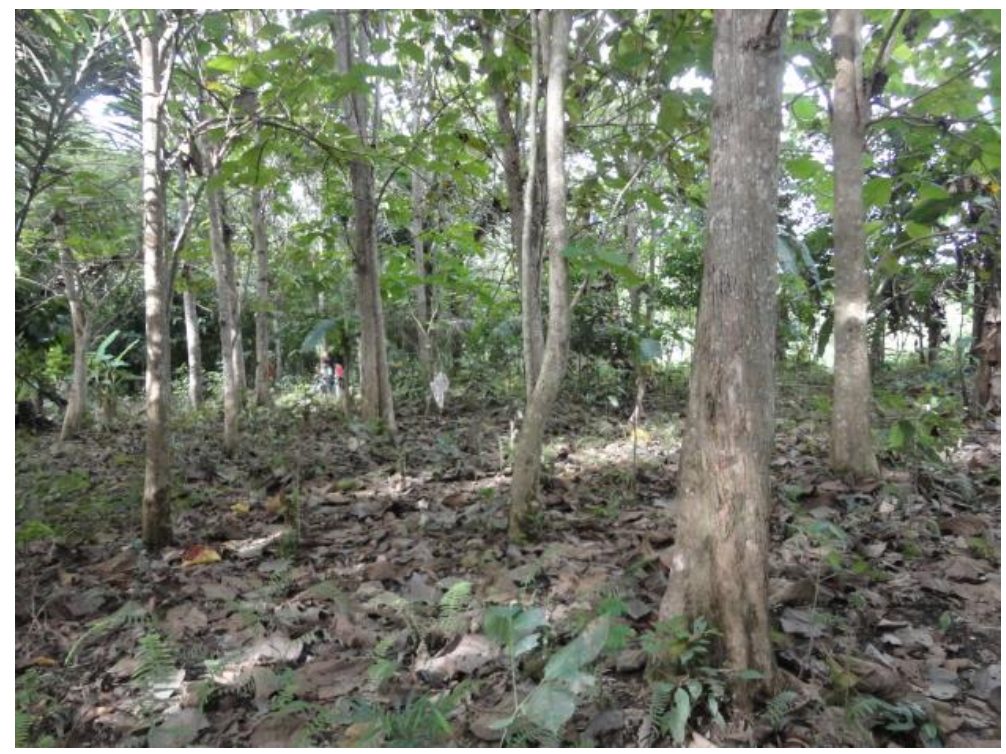

Figure 29. Teak agroforest in Kutai Timur

A plot of teak agroforest were sampled in Birang Village, Gunung Tabur, Berau at $2.20875^{\circ}$ and $117.46035^{\circ}$. Semi intensive management were implemented with weeding activity and using herbicides. Teak was planted in 5 x 5 meters distance. Coffee and cacao were interspersed between teak (Figure 30).
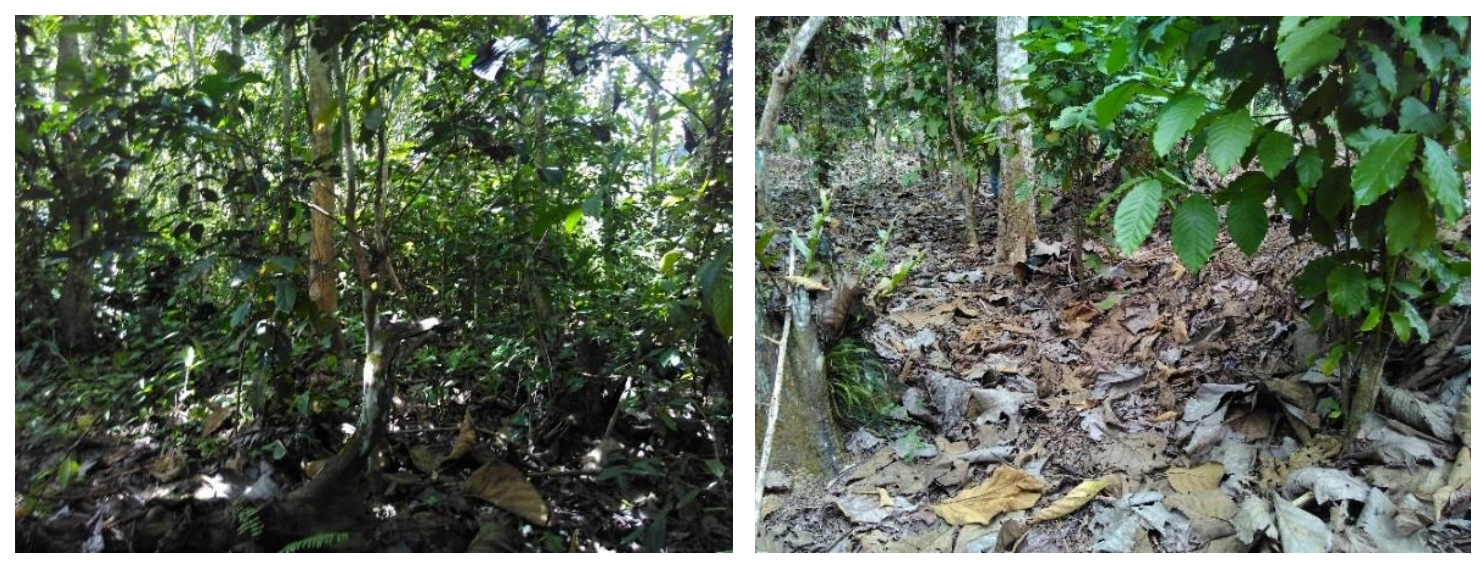

Figure 30. Teak agroforest in Berau

\subsubsection{Teak monoculture}

A plot of teak monoculture was set up in Kerang Dayo Village, Batu Engau, Pasir at $-2.304956^{\circ}$ and $116.03844^{\circ}$ (Figure 31). 


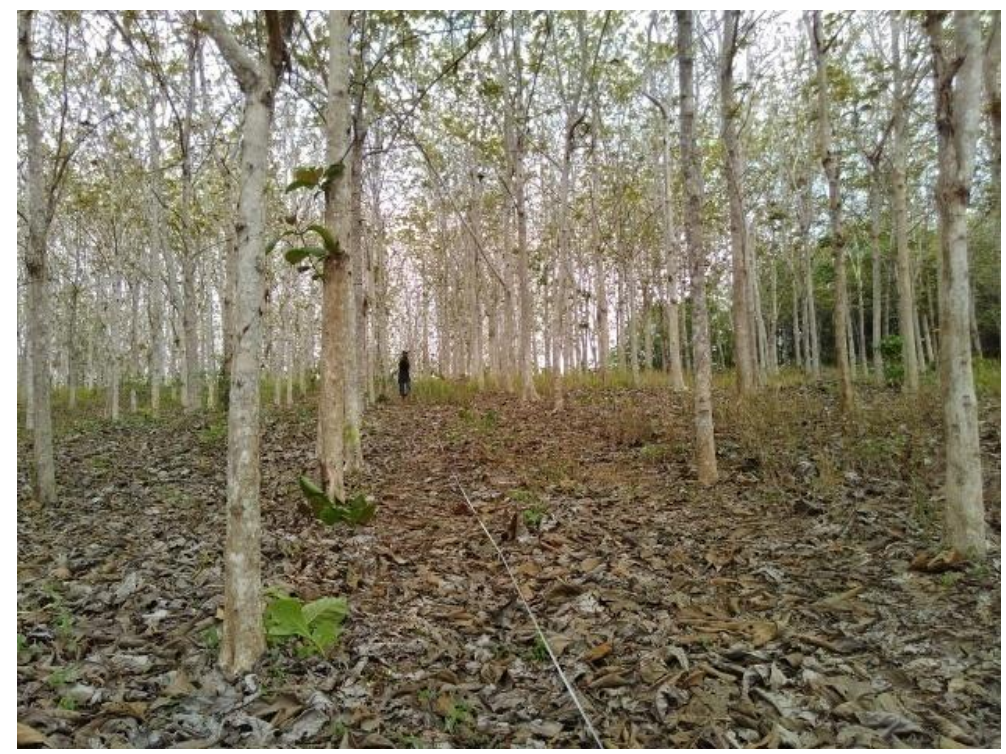

Figure 31. Teak monoculture in Pasir

A plot of teak monoculture was set up in Birang Village, Gunung Tabur, Berau at $2.20717^{\circ}$ and $117.47246^{\circ}$. The plantation established by migrant from South Sulawesi in $3 \times 3 \mathrm{~m}$ distance (Figure 32). Seeds were obtained from government program. Semi-intensive land management was implemented by weeding and fertilizing.

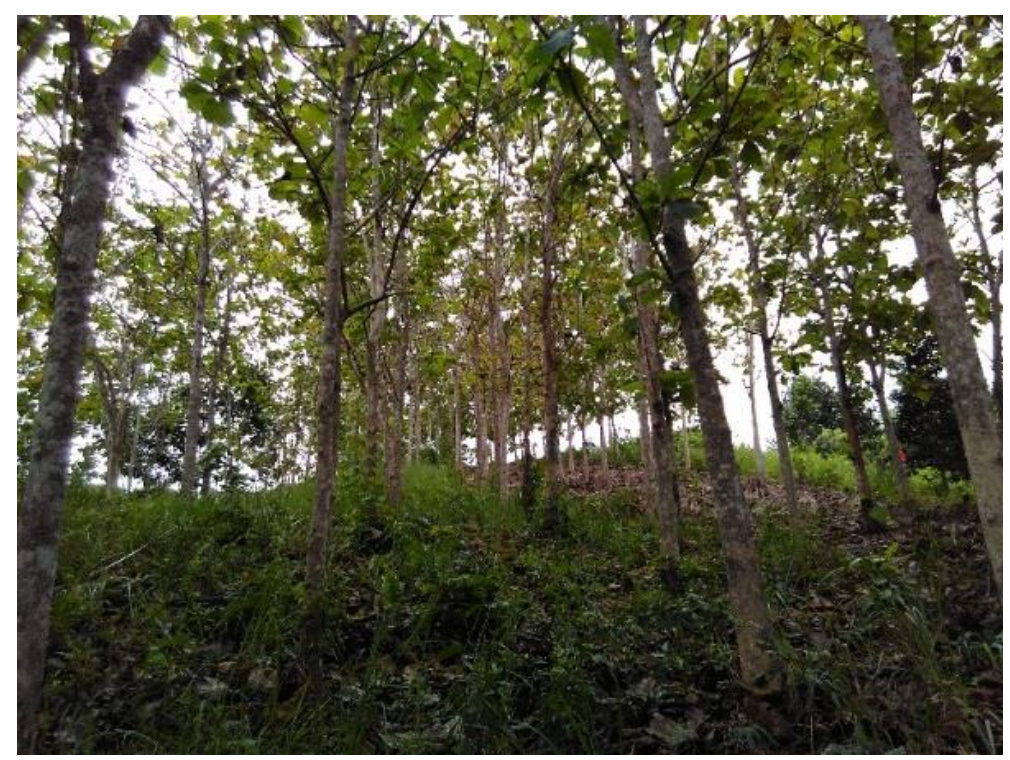

Figure 32. Teak monoculture in Berau

\subsubsection{Home garden}

A plot of home garden was set up Pasir Jaya Hamlet, Padang Pangrapat Village, Tanah Grogot, Pasir in at $-1.84271^{\circ}$ and $116.23861^{\circ}$. The home garden found in almost home yard among the village, mostly planted with coconut trees, other fruit trees or cassava (Figure 33). 


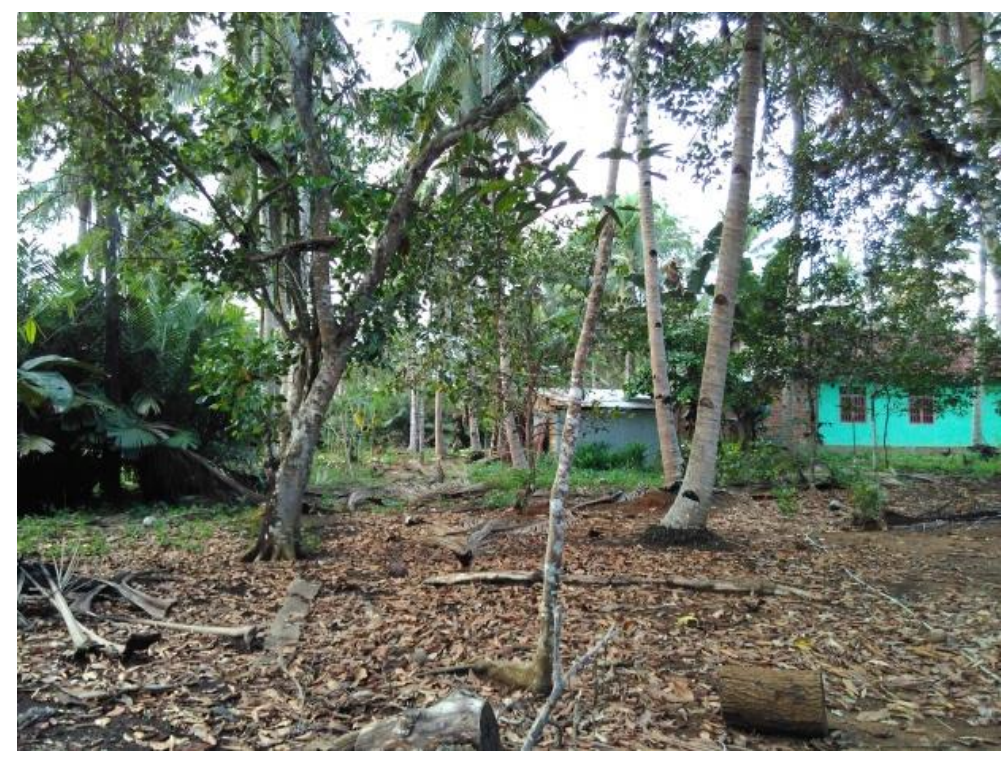

Figure 33. Home garden in Pasir

\subsubsection{Sengon monoculture}

A plot of sengon monoculture was set up in Petangis Village, Batu Engau, Pasir at $-2.077236^{\circ}$ and $116.099164^{\circ}$. Sengon (Paraserianthes falcataria) is part of reclamation activity after coal mining operation (Figure 34).

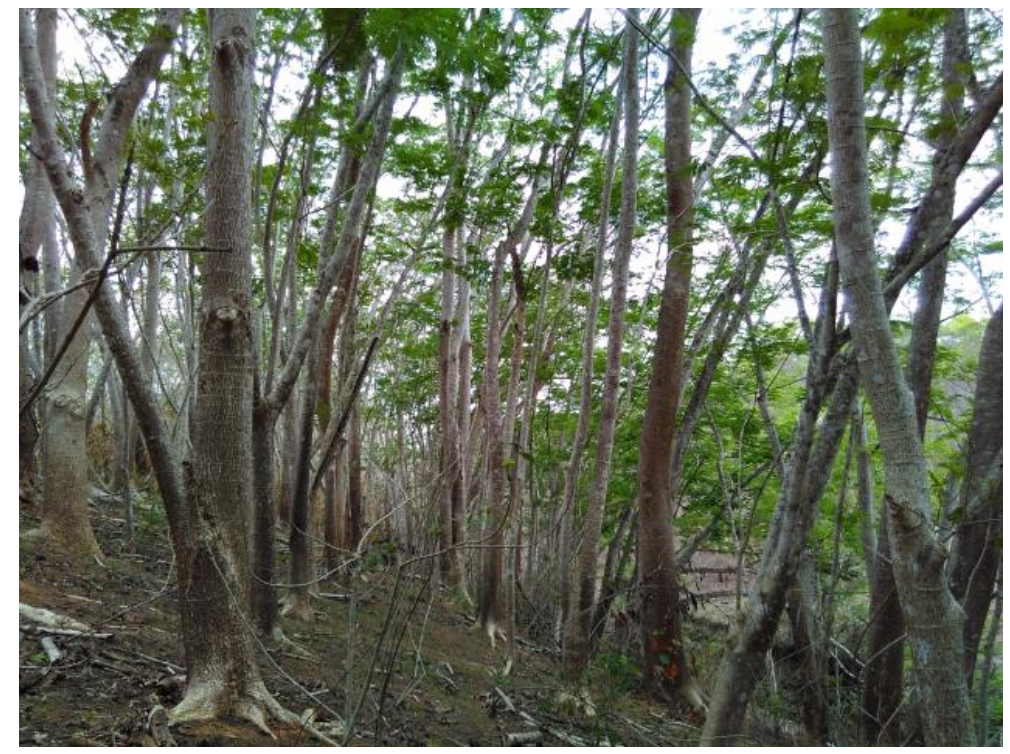

Figure 34. Sengon monoculture in Pasir

A plot of sengon plantation set up in Campursari village, Batu Putih, Berau at $1.48967^{\circ}$ and $118.27122^{\circ}$ (Figure 35). 


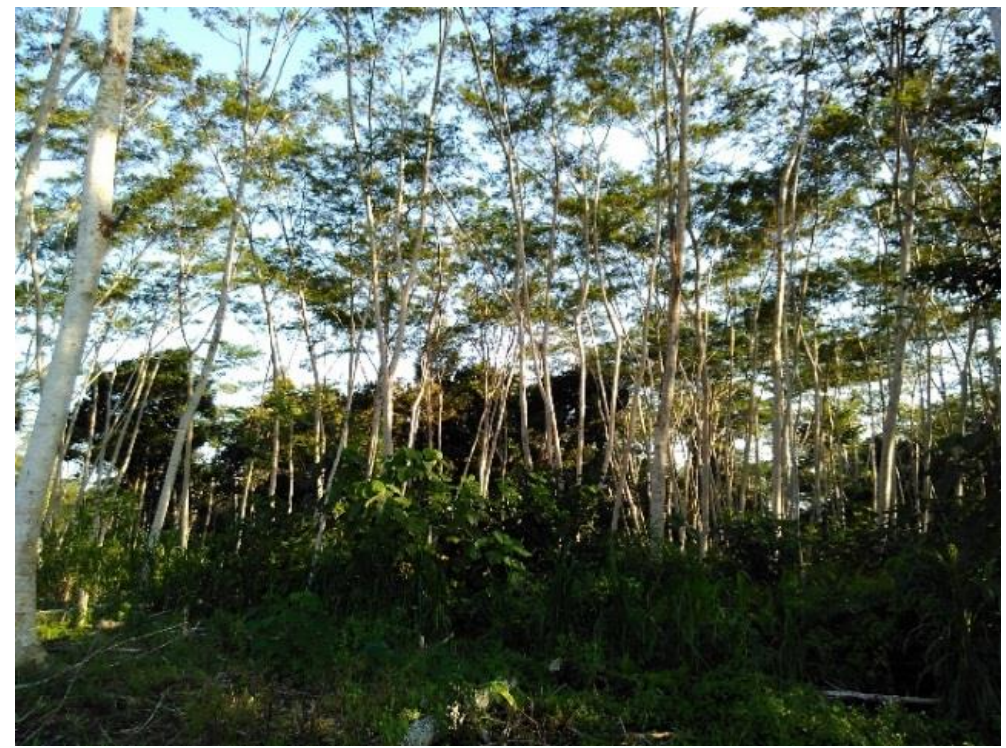

Figure 35. Sengon monoculture in Berau

\subsubsection{Acacia monoculture}

A plot of acacia monoculture was set up in Petangis Village, Batu Engau, Pasir at $-2.071441^{\circ}$ and $116.099323^{\circ}$. Similar to sengon monoculture in Petangis, Acacia auriculiformis is also part of reclamation activity after coal mining.

\subsubsection{Gmelina plantation}

Two plots of gmelina plantion set up at km 14 Sangatta Selatan, Kutai Timur at $0.437751^{\circ}$ and $117.476844^{\circ}$ (Figure 33).

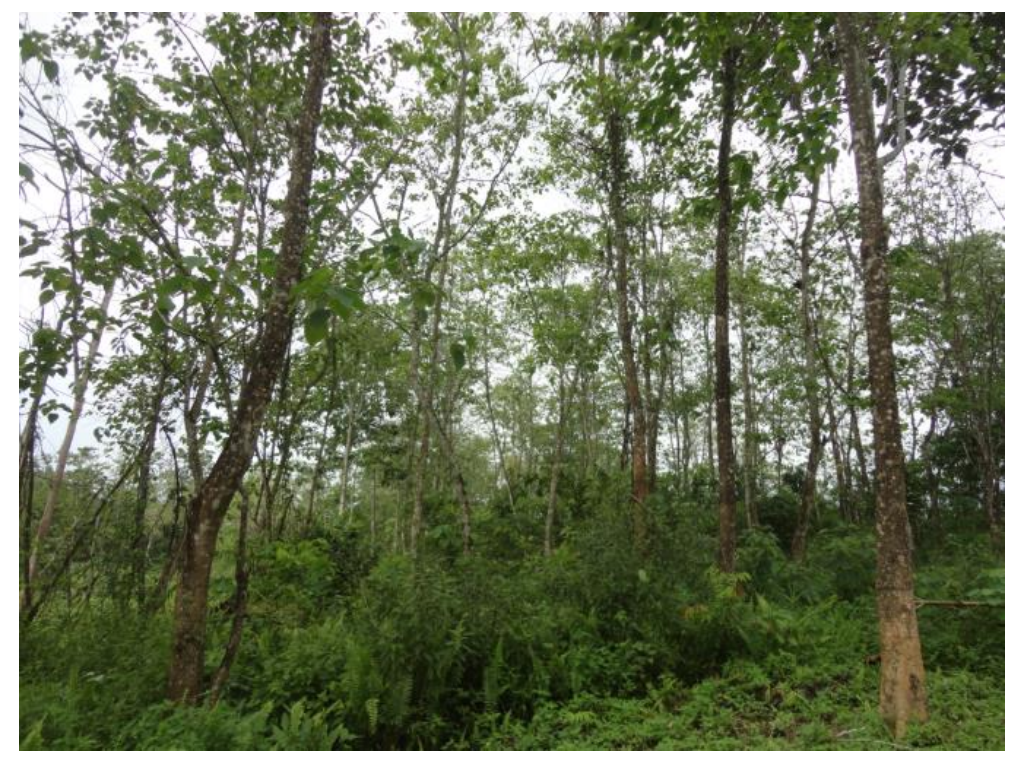

Figure 36. Gmelina plantation in Kutai Timur

A plot of gmelina plantation was set up in Swan Slutung Village, Muara Komam, Pasir at $-1.419038^{\circ}$ and $115.884606^{\circ}$. Gmelina planted at 2003 in 2.5 distances (Figure 37). 


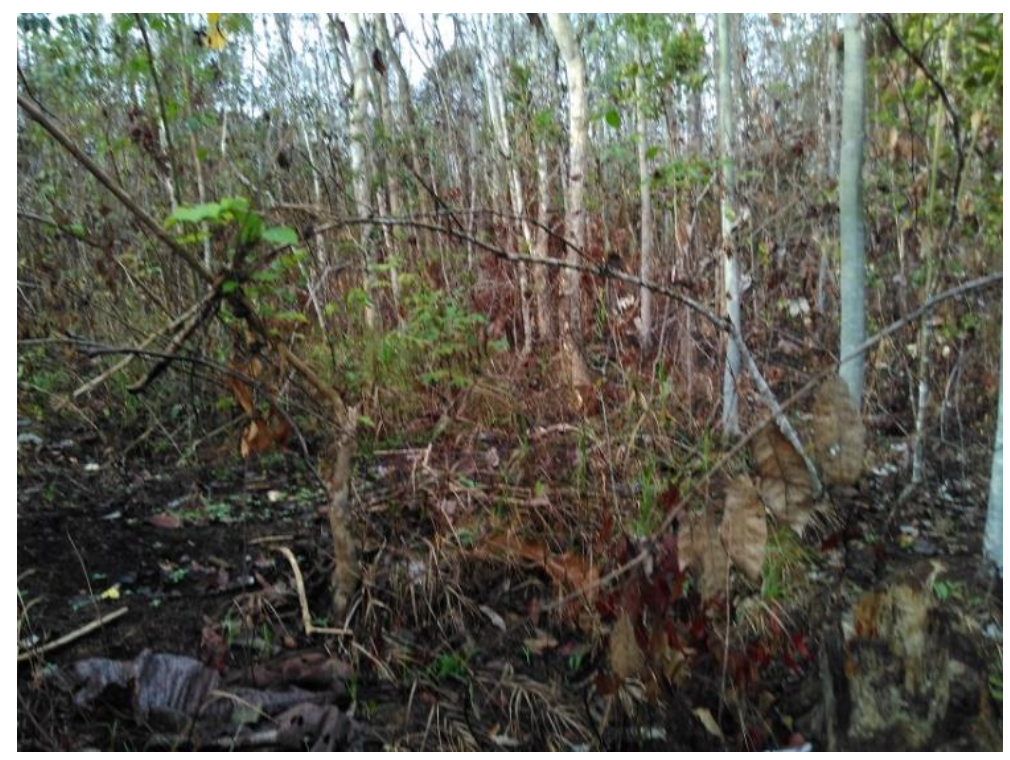

Figure 37. Gmelina plantation in Pasir

A plot of abandoned Gmelina plantation set up in Biatan, Berau at $1.61700^{\circ}$ and $118.14799^{\circ}$. Gmelina planted in 5 x 5 meters distance. Another plot of Gmelina plantation was set up in PT. Sumalindo Alam Lestari which is established in 1985 at $1.42594^{\circ}$ and $118.33547^{\circ}$ (Figure 38).
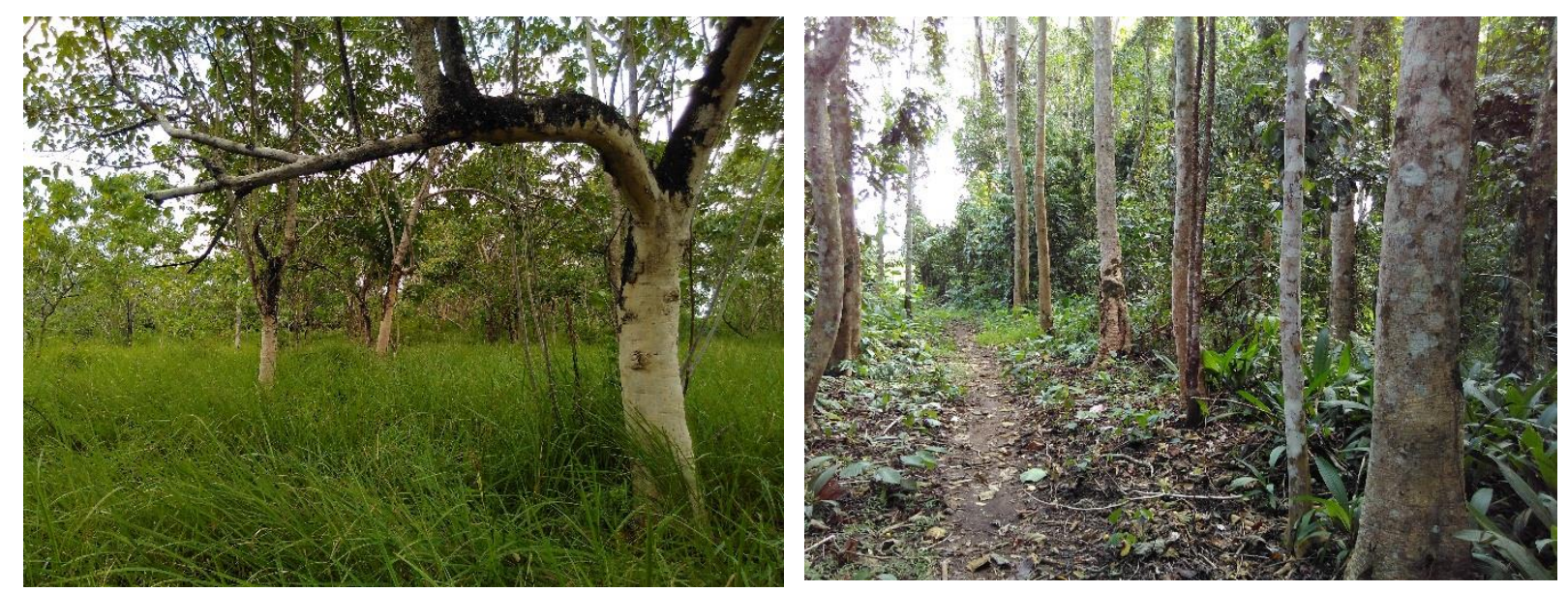

Figure 38. Gmelina plantation in Biatan (left) and in PT Sumalindo Alam Lestari (right), Berau

\subsubsection{Gaharu agroforest}

A plots of gaharu agroforest was set up in Muara Lesan Village, Kelay, Berau at $1.71591^{\circ}$ and 117.17607 . Gaharu, Aquilaria microcarpa and Gyrinops sp from wild seedlings domesticated in the mixed system with rubber (Figure 39). 


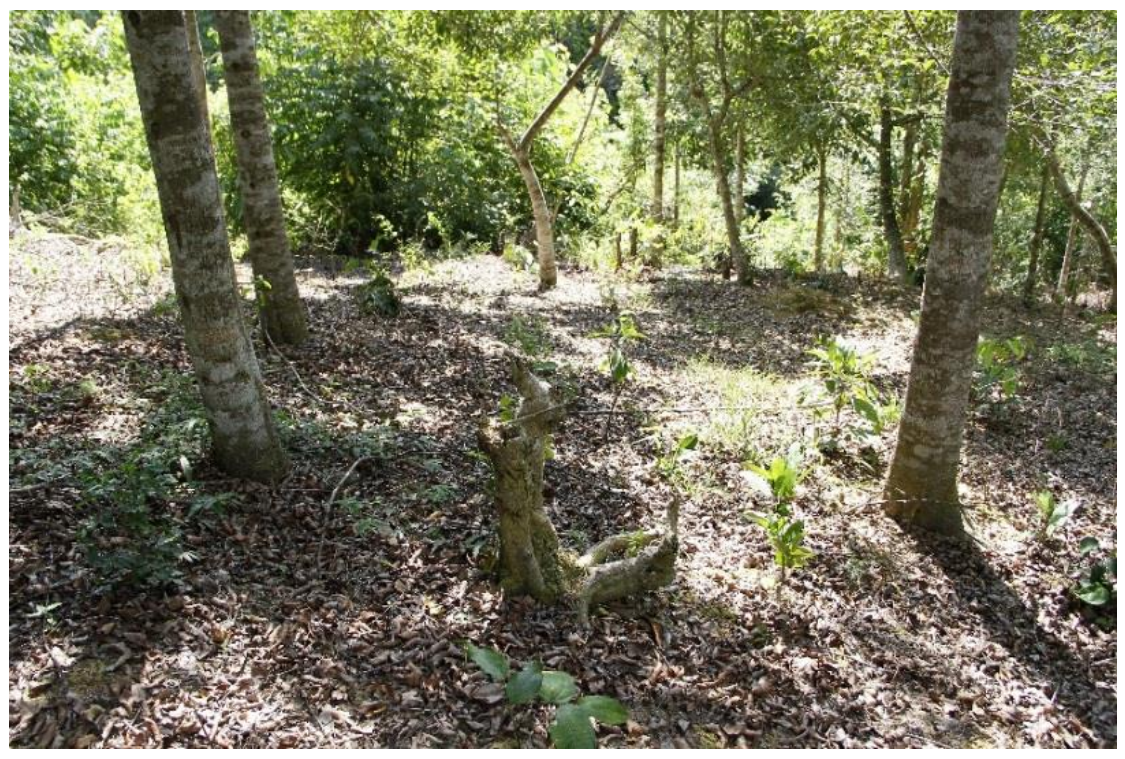

Figure 39. Gaharu agroforest in Berau

\subsection{Tree Species Composition}

\subsubsection{Species Richness}

Generally, tree species richness in three districts of Kutai Timur, Pasir and Berau have different characteristic depend on the management applied in the systems (Table 3). Natural regeneration with limited management such as undisturbed forest and logged-over forest hold high species richness for all growth stages. Logged-over forest high density in Berau and undisturbed forest in Pasir has highest species richness, 116 species in 3 plots and 107 species in 2 plots, respectively. However, disturbed and undisturbed mangrove in Berau tends to be occupied by certain species.

Low intensive management of fruit-based agroforest provides habitat for tree species, both cultivated economically and wild of naturally regeneration. Species richness of fruit-based agroforestry in Kutai Timur is higher than logged-over forest low density, in Pasir is similar, but in Berau even higher than undisturbed forest.

Species richness in agroforestry systems such as cacao, teak and rubber tend to lower species richness than the low management of fruit-based agroforest, but higher than the monoculture systems.

Interestingly, gmelina plantation in three district samples of East Kalimantan consists of $15-24$

species richness for all growth stages. 
Table 3.Tree species richness in various land use types of Kutai Timur, Pasir and Berau District, East Kalimantan

\begin{tabular}{|c|c|c|c|c|c|c|c|}
\hline & \multirow[b]{2}{*}{ Land cover } & \multirow[b]{2}{*}{ No. of plot } & \multicolumn{5}{|c|}{ Number of species } \\
\hline & & & Seedling & Sapling & Pole & Tree & $\begin{array}{l}\text { All growth } \\
\text { stages }\end{array}$ \\
\hline \multirow[t]{12}{*}{ Kutai Timur } & Logged-over forest low density & 2 & 10 & 16 & 18 & 21 & 37 \\
\hline & Undisturbed mangrove & 3 & 2 & 3 & 1 & 3 & 3 \\
\hline & Disturbed mangrove & 3 & 8 & 9 & 6 & 9 & 12 \\
\hline & Fruit-based agroforest & 4 & 29 & 20 & 12 & 61 & 85 \\
\hline & Teak agroforest & 1 & 8 & 4 & 0 & 13 & 20 \\
\hline & Rubber agroforest & 1 & 7 & 3 & 1 & 2 & 8 \\
\hline & Rubber monoculture & 2 & 2 & 2 & 1 & 1 & 3 \\
\hline & Coconut monoculture & 3 & 3 & 2 & 3 & 3 & 5 \\
\hline & Cacao agroforest & 3 & 8 & 3 & 4 & 19 & 22 \\
\hline & Citrus monoculture & 1 & 3 & 3 & 3 & 4 & 8 \\
\hline & Pepper agroforest & 1 & 0 & 0 & 0 & 2 & 2 \\
\hline & Gmelina plantation & 2 & 9 & 5 & 3 & 8 & 15 \\
\hline \multirow[t]{13}{*}{ Pasir } & Undisturbed forest & 2 & 31 & 23 & 24 & 69 & 107 \\
\hline & Logged-over forest high density & 1 & 8 & 12 & 9 & 46 & 60 \\
\hline & Logged-over forest low density & 1 & 6 & 4 & 9 & 19 & 27 \\
\hline & Logged-over swamp forest & 2 & 7 & 7 & 12 & 23 & 36 \\
\hline & Fruit-based agroforest & 2 & 11 & 3 & 4 & 13 & 25 \\
\hline & Undisturbed mangrove & 2 & 4 & 2 & 4 & 2 & 4 \\
\hline & Home garden & 1 & 0 & 1 & 3 & 13 & 14 \\
\hline & Rubber agroforest & 1 & 16 & 3 & 3 & 6 & 21 \\
\hline & Rubber monoculture & 1 & 3 & 2 & 1 & 1 & 3 \\
\hline & Teak monoculture & 1 & 2 & 0 & 1 & 1 & 2 \\
\hline & Acacia monoculture & 1 & 0 & 0 & 1 & 2 & 2 \\
\hline & Sengon monoculture & 1 & 7 & 4 & 2 & 2 & 11 \\
\hline & Gmelina plantation & 1 & 5 & 7 & 8 & 9 & 15 \\
\hline \multirow[t]{11}{*}{ Berau } & Undisturbed forest & 2 & 14 & 22 & 22 & 41 & 57 \\
\hline & Logged-over forest high density & 3 & 36 & 26 & 23 & 82 & 116 \\
\hline & Undisturbed mangrove & 2 & 2 & 2 & 1 & 2 & 2 \\
\hline & Disturbed mangrove & 1 & 1 & 0 & 1 & 1 & 1 \\
\hline & Fruit-based agroforest & 11 & 23 & 12 & 14 & 37 & 56 \\
\hline & Gaharu agroforest & 1 & 2 & 0 & 3 & 5 & 7 \\
\hline & Coconut agroforest & 1 & 2 & 0 & 0 & 5 & 7 \\
\hline & Pepper agroforest & 2 & 6 & 3 & 6 & 2 & 10 \\
\hline & Teak agroforest & 1 & 4 & 2 & 2 & 2 & 7 \\
\hline & Teak monoculture & 1 & 3 & 0 & 1 & 1 & 3 \\
\hline & Gmelina plantation & 3 & 12 & 9 & 7 & 5 & 24 \\
\hline
\end{tabular}

\subsubsection{Dominance Species}

Important Value Index (IVI) used to express dominance species in the sampled plot which is represented species composition in the land use system. High IVI species indicate dominant species (Table 4). 
Table 4. Three highest IVI species of all growth stages in various land cover systems in Kutai Timur, Pasir and Berau District, East Kalimantan

\begin{tabular}{|c|c|c|c|c|}
\hline Land cover & Seedling & Sapling & Pole & Tree \\
\hline \multicolumn{5}{|c|}{ KUTAI TIMUR } \\
\hline \multirow{3}{*}{$\begin{array}{l}\text { Logged-over } \\
\text { forest low } \\
\text { density }\end{array}$} & Millettia sericea & Millettia sericea & Vitex pubescens & Vitex pubescens \\
\hline & Tetracera scandens & Vitex pubescens & Macaranga triloba & Endospermum \\
\hline & $\begin{array}{l}\text { Endospermum } \\
\text { diadenum }\end{array}$ & $\begin{array}{l}\text { Endospermum } \\
\text { diadenum }\end{array}$ & $\begin{array}{l}\text { Endospermum } \\
\text { diadenum }\end{array}$ & $\begin{array}{l}\text { diadenum } \\
\text { Macaranga triloba }\end{array}$ \\
\hline \multirow{3}{*}{$\begin{array}{l}\text { Undisturbed } \\
\text { mangrove }\end{array}$} & Rhizophora apiculata & Rhizophora apiculata & Rhizophora apiculata & Rhizophora apiculata \\
\hline & Rhizophora mucronata & Rhizophora mucronata & - & Rhizophora stylosa \\
\hline & - & Rhizophora stylosa & - & Rhizophora mucronata \\
\hline \multirow{3}{*}{$\begin{array}{l}\text { Disturbed } \\
\text { mangrove }\end{array}$} & Ceriops tagal & Ceriops tagal & Ceriops tagal & Lumnitzera littorea \\
\hline & Lumnitzera littorea & Rhizophora apiculata & Thespesia populnea & Ceriops tagal \\
\hline & Rhizophora apiculata & Bruguiera gymnorrhiza & Lumnitzera littorea & Thespesia populnea \\
\hline \multirow{3}{*}{$\begin{array}{l}\text { Fruit-based } \\
\text { agroforest }\end{array}$} & Millettia sericea & Sarcotheca diversifolia & Theobroma cacao & Nephelium lappaceum \\
\hline & Vitex pubescens & Endospermum & Mangifera indica & Mangifera indica \\
\hline & $\begin{array}{l}\text { Endospermum } \\
\text { diadenum }\end{array}$ & $\begin{array}{l}\text { diadenum } \\
\text { Vitex pubescens }\end{array}$ & $\begin{array}{l}\text { Endospermum } \\
\text { diadenum }\end{array}$ & Artocarpus champeden \\
\hline \multirow{3}{*}{$\begin{array}{l}\text { Teak } \\
\text { agroforest }\end{array}$} & Ficus septica & Cratoxylum formosum & - & Tectona grandis \\
\hline & Hibiscus tiliaceus & Hibiscus tiliaceus & - & Albizia chinensis \\
\hline & Nephelium lappaceum & Tectona grandis & - & Hibiscus tiliaceus \\
\hline \multirow{3}{*}{$\begin{array}{l}\text { Rubber } \\
\text { agroforest }\end{array}$} & Fagraea racemosa & Ardisia sanguinolenta & Hevea brasiliensis & Hevea brasiliensis \\
\hline & Macaranga triloba & Leucaena leucocephala & - & Leucaena leucocephala \\
\hline & Macaranga tanarius & Macaranga tanarius & - & - \\
\hline \multirow{2}{*}{$\begin{array}{l}\text { Rubber } \\
\text { monoculture }\end{array}$} & Fagraea racemosa & Hevea brasiliensis & Hevea brasiliensis & Hevea brasiliensis \\
\hline & Hevea brasiliensis & Alstonia scholaris & - & -- \\
\hline \multirow{3}{*}{$\begin{array}{l}\text { Coconut } \\
\text { monoculture }\end{array}$} & Leucaena leucocephala & Cocos nucifera & Leucaena leucocephala & Cocos nucifera \\
\hline & Homalanthus populneus & Leucaena leucocephala & Acacia auriculiformis & Leucaena leucocephala \\
\hline & Cocos nucifera & - & $\begin{array}{l}\text { Artocarpus } \\
\text { heterophyllus }\end{array}$ & $\begin{array}{l}\text { Artocarpus } \\
\text { heterophyllus }\end{array}$ \\
\hline \multirow{3}{*}{$\begin{array}{l}\text { Cacao } \\
\text { monoculture }\end{array}$} & Anacardium occidentale & Theobroma cacao & Theobroma cacao & Theobroma cacao \\
\hline & Hevea brasiliensis & Durio zibethinus & Artocarpus champeden & Durio zibethinus \\
\hline & Theobroma cacao & Homalanthus populneus & Piper aduncum & Leucaena leucocephala \\
\hline \multirow{3}{*}{$\begin{array}{l}\text { Citrus } \\
\text { monoculture }\end{array}$} & Homalanthus populneus & Citrus aurantifolia & Citrus aurantifolia & Citrus aurantifolia \\
\hline & Gliricidia sepium & Gliricidia sepium & Theobroma cacao & Artocarpus elasticus \\
\hline & Citrus aurantifolia & Lansium domesticum & Artocarpus champeden & Durio zibethinus \\
\hline \multirow{2}{*}{$\begin{array}{l}\text { Pepper } \\
\text { agroforest }\end{array}$} & - & - & - & Gliricidia sepium \\
\hline & - & - & - & Nephelium lappaceum- \\
\hline \multirow{4}{*}{$\begin{array}{l}\text { Gmelina } \\
\text { plantation }\end{array}$} & Hibiscus tiliaceus & Hevea brasiliensis & Gmelina arborea & Gmelina arborea \\
\hline & Vitex pubescens & Vitex pubescens & Hevea brasiliensis & Artocarpus \\
\hline & Hevea brasiliensis & Dillenia indica & Mallotus macrostachyus & heterophyllus \\
\hline & & & & Vitex pubescens \\
\hline \multicolumn{5}{|c|}{ PASIR } \\
\hline \multirow{3}{*}{$\begin{array}{l}\text { Undisturbed } \\
\text { forest }\end{array}$} & Shorea acuminata & Shorea acuminata & Sageraea elliptica & Heritiera javanica \\
\hline & Shorea platyclados & Heritiera javanica & Polyalthia glauca & Dipterocarpus sp. \\
\hline & Fabaceae sp.1 & Polyalthia glauca & Baccaurea stipulata & Shorea acuminata \\
\hline \multirow{3}{*}{$\begin{array}{l}\text { Logged-over } \\
\text { forest high } \\
\text { density }\end{array}$} & Rhodamnia cinerea & Rhodamnia cinerea & Memecylon oligoneurum & Aporosa lucida \\
\hline & Buchanania arborescens & Aporosa symplocoides & Archidendron ellipticum & Artocarpus elasticus \\
\hline & Tetracera fagifolia & Glochidion rubrum & Beilschmiedia sp. 1 & Cratoxylum sp. \\
\hline $\begin{array}{l}\text { Logged-over } \\
\text { forest low }\end{array}$ & Schima wallichii & Syzygium claviflorum & Schima wallichii & Artocarpus integer \\
\hline
\end{tabular}




\begin{tabular}{|c|c|c|c|c|}
\hline Land cover & Seedling & Sapling & Pole & Tree \\
\hline \multirow[t]{2}{*}{ density } & Xanthophyllum sp. & Barringtonia lanceolata & Rhodamnia cinerea & Parartocarpus sp.1 \\
\hline & Syzygium claviflorum & Macaranga triloba & $\begin{array}{l}\text { Syzygium } \\
\text { acuminatissimum }\end{array}$ & Xanthophyllum sp. \\
\hline \multirow{3}{*}{$\begin{array}{l}\text { Logged-over } \\
\text { swamp forest }\end{array}$} & Macaranga triloba & Peronema canescens & Melaleuca leucadendra & Melaleuca leucadendra \\
\hline & Homalanthus giganteus & Alstonia spatulata & Peronema canescens & Vitex pinnata \\
\hline & Elaeocarpus stipularis & Melaleuca leucadendra & Vitex pinnata & Gardenia tubifera \\
\hline \multirow{4}{*}{$\begin{array}{l}\text { Fruit-based } \\
\text { agroforest }\end{array}$} & Nephelium lappaceum & Vitex pinnata & Mangifera indica & Durio zibethinus \\
\hline & Melastoma & Dolichandrone & Syzygium aqueum & Nephelium lappaceum \\
\hline & malabathricum & spathacea & Dolichandrone & Lansium domesticum \\
\hline & Micromelum pubescens & Macaranga hypoleuca & spathacea & \\
\hline \multirow{3}{*}{$\begin{array}{l}\text { Undisturbed } \\
\text { mangrove }\end{array}$} & Rhizophora apiculata & Rhizophora apiculata & Rhizophora apiculata & Rhizophora apiculata \\
\hline & Ceriops tagal & Bruguiera parviflora & Bruguiera parviflora & Bruguiera parviflora \\
\hline & Bruguiera parviflora & - & Ceriops tagal & - \\
\hline \multirow[t]{4}{*}{ Home garden } & - & Aquilaria malaccensis & Cinnamomum & Cocos nucifera \\
\hline & - & - & porrectum & Nephelium lappaceum \\
\hline & - & - & Nephelium lappaceum & Parkia speciosa \\
\hline & & & Syzygium aqueum & \\
\hline \multirow{3}{*}{$\begin{array}{l}\text { Rubber } \\
\text { agroforest }\end{array}$} & Hevea brasiliensis & Hevea brasiliensis & Hevea brasiliensis & Hevea brasiliensis \\
\hline & Psychotria viridiflora & Nephelium lappaceum & Artocarpus integer & Artocarpus integer \\
\hline & Artocarpus integer & Rhodamnia cinerea & Artocarpus rigidus & Ixonanthes petiolaris \\
\hline \multirow{3}{*}{$\begin{array}{l}\text { Rubber } \\
\text { monoculture }\end{array}$} & Hevea brasiliensis & Hevea brasiliensis & Hevea brasiliensis & Hevea brasiliensis \\
\hline & Elaeocarpus stipularis & Elaeocarpus stipularis & - & - \\
\hline & Ilex sp.1 & - & - & - \\
\hline \multirow{2}{*}{$\begin{array}{l}\text { Teak } \\
\text { monoculture }\end{array}$} & Tectona grandis & - & Tectona grandis & Tectona grandis \\
\hline & Palaquium sp.1- & - & - & - \\
\hline \multirow{2}{*}{$\begin{array}{l}\text { Acacia } \\
\text { monoculture }\end{array}$} & - & - & Acacia auriculiformis & Acacia auriculiformis \\
\hline & - & - & - & Vitex pinnata- \\
\hline \multirow{3}{*}{$\begin{array}{l}\text { Sengon } \\
\text { monoculture }\end{array}$} & Vitex pinnata & Artocarpus dadah & Albizia chinensis & Albizia chinensis \\
\hline & Clausena excavata & Clausena excavata & Artocarpus dadah & Acacia auriculiformis \\
\hline & Aporosa lucida & Rhodamnia cinerea & - & - \\
\hline \multirow{3}{*}{$\begin{array}{l}\text { Gmelina } \\
\text { plantation }\end{array}$} & Macaranga sp. & Mallotus paniculatus & Peronema canescens & Gmelina arborea \\
\hline & Gmelina arborea & Macaranga sp. & Buchanania sessilifolia & Peronema canescens \\
\hline & Mallotus paniculatus & Macaranga gigantea & Macaranga sp. & Dyera costulata \\
\hline \multicolumn{5}{|c|}{ BERAU } \\
\hline \multirow{3}{*}{$\begin{array}{l}\text { Undisturbed } \\
\text { forest }\end{array}$} & Coccoceras borneense & Koilodepas brevipes & Polyalthia lateriflora & Polyalthia lateriflora \\
\hline & Koilodepas brevipes & Polyalthia lateriflora & Nephelium uncinatum & Elateriospermum tapos \\
\hline & Shorea sp. 4 & Antidesma coriaceum & Baccaurea sumatrana & Harpullia arborea \\
\hline \multirow{3}{*}{$\begin{array}{l}\text { Logged-over } \\
\text { forest high } \\
\text { density }\end{array}$} & Pentace adenophora & Polyalthia lateriflora & Baccaurea stipulata & Eusideroxylon zwageri \\
\hline & Polyalthia lateriflora & Macaranga hypoleuca & Polyalthia lateriflora & Shorea cf. leprosula \\
\hline & Eusideroxylon zwageri & Pentace adenophora & Microcos crassifolia & Baccaurea stipulata \\
\hline \multirow{3}{*}{$\begin{array}{l}\text { Undisturbed } \\
\text { mangrove }\end{array}$} & Rhizophora apiculata & Rhizophora apiculata & Rhizophora apiculata & Rhizophora apiculata \\
\hline & Sonneratia alba & Sonneratia alba & - & Sonneratia alba \\
\hline & - & - & - & \\
\hline $\begin{array}{l}\text { Disturbed } \\
\text { mangrove }\end{array}$ & Sonneratia alba & - & Sonneratia alba & Sonneratia alba \\
\hline \multirow{3}{*}{$\begin{array}{l}\text { Fruit-based } \\
\text { agroforest }\end{array}$} & Coffea canephora & Theobroma cacao & Theobroma cacao & Theobroma cacao \\
\hline & Theobroma cacao & Coffea canephora & Hevea brasiliensis & Lansium domesticum \\
\hline & Nephelium lappaceum & Hevea brasiliensis & Nephelium lappaceum & Nephelium lappaceum \\
\hline Gaharu & Gliricidia sepium & - & Gyrinops sp. & Aquilaria microcarpa \\
\hline
\end{tabular}




\begin{tabular}{|c|c|c|c|c|}
\hline Land cover & Seedling & Sapling & Pole & Tree \\
\hline \multirow[t]{2}{*}{ agroforest } & Mallotus sp. 2 & - & Hevea brasiliensis & Hevea brasiliensis \\
\hline & - & - & Aquilaria microcarpa & Gyrinops sp. \\
\hline \multirow{3}{*}{$\begin{array}{l}\text { Coconut } \\
\text { agroforest }\end{array}$} & Homalanthus populneus & - & - & Cocos nucifera \\
\hline & Annona muricata & - & - & Mangifera indica \\
\hline & - & - & - & Averrhoa bilimbi \\
\hline \multirow{3}{*}{$\begin{array}{l}\text { Pepper } \\
\text { agroforest }\end{array}$} & Leucaena leucocephala & Gliricidia sepium & Gliricidia sepium & Gliricidia sepium \\
\hline & Vitex pinnata & Leucaena leucocephala & Leucaena leucocephala & Leucaena leucocephala \\
\hline & - & Moringa oleifera & Moringa oleifera & - \\
\hline \multirow{3}{*}{$\begin{array}{l}\text { Teak } \\
\text { agroforest }\end{array}$} & Coffea canephora & Coffea canephora & Nephelium lappaceum & Tectona grandis \\
\hline & Macaranga triloba & Macaranga hypoleuca & Psidium guajava & Nephelium lappaceum \\
\hline & Tectona grandis & - & - & - \\
\hline \multirow{3}{*}{$\begin{array}{l}\text { Teak } \\
\text { Monoculture }\end{array}$} & Vitex pinnata & - & - & Tectona grandis \\
\hline & Senna siamea & - & - & - \\
\hline & Tectona grandis & - & - & - \\
\hline \multirow{3}{*}{$\begin{array}{l}\text { Gmelina } \\
\text { plantation }\end{array}$} & Homalanthus populneus & Gmelina arborea & Gmelina arborea & Gmelina arborea \\
\hline & Macaranga hypoleuca & Coffea canephora & Piper aduncum & Falcataria mollucana \\
\hline & Piper aduncum & Leea indica & Nauclea sp. & Harpullia arborea \\
\hline
\end{tabular}

Shorea and Dipterocarpus, high value timber production from Dipterocarpaceae are dominant in undisturbed forest of Pasir and Berau. Logged-over forest in Kutai Timur and Pasir dominated by pioneer and sub-climax species, while in Berau is dominated by climax species. Logged-over forest plot in Berau is part of remnant forest which is protected by local government as part of Forest Park for ecotourism purposes. Rhizophora that consist of apiculata, mucronata and stylosa are dominant species in undisturbed mangrove of Kutai Timur, Pasir and Berau. Ceriops tagal and Lutmnitzera littorea dominant in disturbed mangrove of Kutai Timur, but Sonneratia sp. in Berau.

Rambutan (Nephelium lappaceum), durian (Durio zibethinus) and duku (Lansium domesticum) are the common dominant species is fruit-based agroforestry systems in East Kalimantan.

\subsubsection{Similarity Species among Land cover}

A similarity index determines how closely the current vegetation community resembles either the potential natural community or some other reference community. Similarity index among land use system in three districts of Kutai Timur, Pasir and Berau varied depend on the land use comparison (Table 5, 6 and 7).

Table 5. Similarity matrix of species among land uses systems in each growth stage in Kutai Timur

\begin{tabular}{|c|c|c|c|c|c|c|c|c|c|c|c|c|}
\hline Land cover & CA & $\mathrm{CiM}$ & CoM & DM & FA & GP & TA & LOF & PM & RA & $\mathbf{R M}$ & UM \\
\hline \multicolumn{13}{|c|}{ Seedling } \\
\hline Cacao agroforest (CA) & 1 & 0.14 & 0.10 & 0 & 0.17 & 0.09 & 0.07 & 0 & 0 & 0.03 & 0.04 & 0 \\
\hline Citrus monoculture (CiM) & & 1 & 0.23 & 0 & 0.10 & 0.08 & 0 & 0 & 0 & 0 & 0 & 0 \\
\hline Coconut monoculture (CoM) & & & 1 & 0 & 0.08 & 0.05 & 0 & 0 & 0 & 0 & 0 & 0 \\
\hline Disturbed mangrove (DM) & & & & 1 & 0 & 0 & 0 & 0 & 0 & 0 & 0 & 0 \\
\hline Fruit-based agroforest (FA) & & & & & 1 & 0.11 & 0.10 & 0.26 & 0 & 0.02 & 0.03 & 0.04 \\
\hline Gmelina plantation (GP) & & & & & & 1 & 0.08 & 0.05 & 0 & 0.15 & 0.22 & 0 \\
\hline Teak agroforest (TA) & & & & & & & 1 & 0.06 & 0 & 0 & 0 & 0 \\
\hline Logged-over forest (LOF) & & & & & & & & 1 & 0 & 0 & 0 & 0 \\
\hline
\end{tabular}




\begin{tabular}{|c|c|c|c|c|c|c|c|c|c|c|c|c|}
\hline Land cover & CA & $\mathrm{CiM}$ & CoM & DM & FA & GP & TA & LOF & PM & RA & RM & UM \\
\hline Pepper monoculture (PM) & & & & & & & & & 1 & 0 & 0 & 0 \\
\hline Rubber agroforest (RA) & & & & & & & & & & 1 & 0.31 & 0 \\
\hline Rubber monoculture (RM) & & & & & & & & & & & 1 & 0 \\
\hline Undisturbed mangrove (UM) & & & & & & & & & & & & 1 \\
\hline \multicolumn{13}{|c|}{ Sapling } \\
\hline Cacao agroforest (CA) & 1 & 0 & 0 & 0 & 0 & 0.08 & 0 & 0 & 0 & 0 & 0 & 0 \\
\hline Citrus monoculture (CiM) & & 1 & 0 & 0 & 0.05 & 0 & 0 & 0 & 0 & 0 & 0 & 0 \\
\hline Coconut monoculture (CoM) & & & 1 & 0 & 0 & 0 & 0 & 0 & 0 & 0.2 & 0 & 0 \\
\hline Disturbed mangrove (DM) & & & & 1 & 0 & 0 & 0 & 0 & 0 & 0 & 0 & 0 \\
\hline Fruit-based agroforest (FA) & & & & & 1 & 0.08 & 0.10 & 0.25 & 0 & 0 & 0.05 & 0 \\
\hline Gmelina plantation (GP) & & & & & & 1 & 0 & 0.10 & 0 & 0 & 0.29 & 0 \\
\hline Teak agroforest (TA) & & & & & & & 1 & 0.08 & 0 & 0 & 0 & 0 \\
\hline Logged-over forest (LOF) & & & & & & & & 1 & 0 & 0 & 0 & 0 \\
\hline Pepper monoculture (PM) & & & & & & & & & 1 & 0 & 0 & 0 \\
\hline Rubber agroforest (RA) & & & & & & & & & & 1 & 0 & 0 \\
\hline Rubber monoculture (RM) & & & & & & & & & & & 1 & 0 \\
\hline Undisturbed mangrove (UM) & & & & & & & & & & & & 1 \\
\hline \multicolumn{13}{|c|}{ Pole } \\
\hline Cacao agroforest (CA) & 1 & 0.05 & 0 & 0 & 0.11 & 0 & 0 & 0 & 0 & 0 & 0 & 0 \\
\hline Citrus monoculture (CiM) & & 1 & 0 & 0 & 0.15 & 0 & 0 & 0 & 0 & 0 & 0 & 0 \\
\hline Coconut monoculture (CoM) & & & 1 & 0 & 0 & 0 & 0 & 0 & 0 & 0 & 0 & 0 \\
\hline Disturbed mangrove (DM) & & & & 1 & 0 & 0 & 0 & 0 & 0 & 0 & 0 & 0 \\
\hline Fruit-based agroforest (FA) & & & & & 1 & 0 & 0 & 0.12 & 0 & 0 & 0 & 0 \\
\hline Gmelina plantation (GP) & & & & & & 1 & 0 & 0 & 0 & 0.57 & 0.36 & 0 \\
\hline Teak agroforest (TA) & & & & & & & 1 & 0 & 0 & 0 & 0 & 0 \\
\hline Logged-over forest (LOF) & & & & & & & & 1 & 0 & 0 & 0 & 0 \\
\hline Pepper monoculture (PM) & & & & & & & & & 1 & 0 & 0 & 0 \\
\hline Rubber agroforest (RA) & & & & & & & & & & 1 & 0.59 & 0 \\
\hline Rubber monoculture (RM) & & & & & & & & & & & 1 & 0 \\
\hline Undisturbed mangrove (UM) & & & & & & & & & & & & 1 \\
\hline \multicolumn{13}{|c|}{ Tree } \\
\hline Cacao agroforest (CA) & 1 & 0.01 & 0.00 & 0 & 0.14 & 0.01 & 0.01 & 0.00 & 0.01 & 0.03 & 0.02 & 0 \\
\hline Citrus monoculture (CiM) & & 1 & 0 & 0 & 0.02 & 0 & 0.03 & 0.01 & 0 & 0 & 0 & 0 \\
\hline Coconut monoculture (CoM) & & & 1 & 0 & 0.01 & 0.01 & 0 & 0 & 0 & 0.01 & 0 & 0 \\
\hline Disturbed mangrove (DM) & & & & 1 & 0 & 0 & 0 & 0 & 0 & 0 & 0 & 0 \\
\hline Fruit-based agroforest (FA) & & & & & 1 & 0.02 & 0.07 & 0.10 & 0.01 & 0 & 0 & 0 \\
\hline Gmelina plantation (GP) & & & & & & 1 & 0.01 & 0.01 & 0 & 0.01 & 0.01 & 0 \\
\hline Teak agroforest (TA) & & & & & & & 1 & 0 & 0 & 0 & 0 & 0 \\
\hline Logged-over forest (LOF) & & & & & & & & 1 & 0 & 0 & 0 & 0 \\
\hline Pepper monoculture (PM) & & & & & & & & & 1 & 0 & 0 & 0 \\
\hline Rubber agroforest (RA) & & & & & & & & & & 1 & 0.77 & 0 \\
\hline Rubber monoculture (RM) & & & & & & & & & & & 1 & 0 \\
\hline Undisturbed mangrove (UM) & & & & & & & & & & & & 1 \\
\hline \multicolumn{13}{|c|}{ All growth stage } \\
\hline Cacao agroforest (CA) & 1 & 0.04 & 0.03 & 0 & 0.14 & 0.06 & 0.02 & 0.01 & 0.00 & 0.08 & 0.07 & 0 \\
\hline Citrus monoculture (CiM) & & 1 & 0.04 & 0 & 0.05 & 0.01 & 0.07 & 0 & 0.14 & 0 & 0 & 0 \\
\hline Coconut monoculture (CoM) & & & 1 & 0.01 & 0.03 & 0.02 & 0.01 & 0 & 0 & 0.01 & 0 & 0 \\
\hline Disturbed mangrove (DM) & & & & 1 & 0 & 0 & 0 & 0 & 0 & 0 & 0 & 0 \\
\hline Fruit-based agroforest (FA) & & & & & 1 & 0.05 & 0.09 & 0.21 & 0.01 & 0.01 & 0.01 & 0.01 \\
\hline
\end{tabular}




\begin{tabular}{|c|c|c|c|c|c|c|c|c|c|c|c|c|}
\hline Land cover & CA & Сiм & CoM & DM & FA & GP & TA & LOF & PM & RA & RM & UM \\
\hline Gmelina plantation (GP) & & & & & & 1 & 0.04 & 0.03 & 0 & 0.10 & 0.08 & 0 \\
\hline Teak agroforest (TA) & & & & & & & 1 & 0.02 & 0.02 & 0 & 0 & 0 \\
\hline Logged-over forest (LOF) & & & & & & & & 1 & 0 & 0.01 & 0 & 0 \\
\hline Pepper monoculture (PM) & & & & & & & & & 1 & 0 & 0 & 0 \\
\hline Rubber agroforest (RA) & & & & & & & & & & 1 & 0.71 & 0 \\
\hline Rubber monoculture (RM) & & & & & & & & & & & 1 & 0 \\
\hline Undisturbed mangrove (UM) & & & & & & & & & & & & 1 \\
\hline
\end{tabular}

Basically, species composition among land use systems in Kutai Timur significantly different each other, expressed by low similarity index, even totally dissimilar. Highest similarity found between rubber monoculture and rubber agroforest at seedling, pole and tree stage. Relatively high similarity occurred between rubber agroforest and gmelina plantation for pole stage.

Table 6. Similarity matrix of species among land uses systems in each growth stage in Pasir

\begin{tabular}{|c|c|c|c|c|c|c|c|c|c|c|c|c|c|}
\hline Land cover & AM & FB & GP & HG & LFH & LFL & LsF & RA & RM & SM & TM & UF & UM \\
\hline \multicolumn{14}{|c|}{ Seedling } \\
\hline Acacia monoculture (AM) & 1 & 0 & 0 & 0 & 0 & 0 & 0 & 0 & 0 & 0 & 0 & 0 & 0 \\
\hline Fruit-based agroforest (FA) & & 1 & 0 & 0 & 0.02 & 0 & 0.02 & 0 & 0 & 0.07 & 0 & 0 & 0 \\
\hline Gmelina plantation (GP) & & & 1 & 0 & 0 & 0 & 0 & 0 & 0 & 0 & 0 & 0 & 0 \\
\hline Home garden (HG) & & & & 1 & 0 & 0 & 0 & 0 & 0 & 0 & 0 & 0 & 0 \\
\hline LOF high density (LFD) & & & & & 1 & 0 & 0.06 & 0.12 & 0 & 0.06 & 0 & 0.02 & 0 \\
\hline LOF low density (FLD) & & & & & & 1 & 0 & 0.04 & 0.11 & 0 & 0 & 0 & 0 \\
\hline LOF swamp (LOS) & & & & & & & 1 & 0 & 0.08 & 0 & 0 & 0 & 0 \\
\hline Rubber agroforest (RA) & & & & & & & & 1 & 0.28 & 0 & 0 & 0 & 0 \\
\hline Rubber monoculture (RM) & & & & & & & & & 1 & 0 & 0 & 0 & 0 \\
\hline Sengon monoculture (SM) & & & & & & & & & & 1 & 0 & 0 & 0 \\
\hline Teak monoculture (TM) & & & & & & & & & & & 1 & 0 & 0 \\
\hline Undisturbed forest (UF) & & & & & & & & & & & & 1 & 0 \\
\hline Undisturbed mangrove (UM) & & & & & & & & & & & & & 1 \\
\hline \multicolumn{14}{|c|}{ Sapling } \\
\hline Acacia monoculture (AM) & 1 & 0 & 0 & 0 & 0 & 0 & 0 & 0 & 0 & 0 & 0 & 0 & 0 \\
\hline Fruit-based agroforest (FA) & & 1 & 0 & 0 & 0 & 0 & 0 & 0 & 0 & 0 & 0 & 0 & 0 \\
\hline Gmelina plantation (GP) & & & 1 & 0 & 0 & 0 & 0 & 0 & 0 & 0 & 0 & 0 & 0 \\
\hline Home garden (HG) & & & & 1 & 0 & 0 & 0 & 0 & 0 & 0 & 0 & 0 & 0 \\
\hline LOF high density (LFD) & & & & & 1 & 0.09 & 0 & 0.09 & 0 & 0.08 & 0 & 0 & 0 \\
\hline LOF low density (FLD) & & & & & & 1 & 0 & 0 & 0 & 0 & 0 & 0 & 0 \\
\hline LOF swamp (LOS) & & & & & & & 1 & 0 & 0.13 & 0 & 0 & 0 & 0 \\
\hline Rubber agroforest (RA) & & & & & & & & 1 & 0.33 & 0.17 & 0 & 0 & 0 \\
\hline Rubber monoculture (RM) & & & & & & & & & 1 & 0 & 0 & 0 & 0 \\
\hline Sengon monoculture (SM) & & & & & & & & & & 1 & 0 & 0 & 0 \\
\hline Teak monoculture (TM) & & & & & & & & & & & 1 & 0 & 0 \\
\hline Undisturbed forest (UF) & & & & & & & & & & & & 1 & 0 \\
\hline Undisturbed mangrove (UM) & & & & & & & & & & & & & 1 \\
\hline \multicolumn{14}{|c|}{ Pole } \\
\hline Acacia monoculture (AM) & 1 & 0 & 0 & 0 & 0 & 0 & 0 & 0 & 0 & 0 & 0 & 0 & 0 \\
\hline Fruit-based agroforest (FA) & & 1 & 0 & 0.44 & 0 & 0 & 0 & 0 & 0 & 0 & 0 & 0 & 0 \\
\hline Gmelina plantation (GP) & & & 1 & 0 & 0 & 0 & 0.19 & 0 & 0 & 0 & 0 & 0.04 & 0 \\
\hline Home garden (HG) & & & & 1 & 0 & 0 & 0 & 0 & 0 & 0 & 0 & 0 & 0 \\
\hline
\end{tabular}




\begin{tabular}{|c|c|c|c|c|c|c|c|c|c|c|c|c|c|}
\hline Land cover & AM & FB & GP & HG & LFH & LFL & LsF & RA & $\mathbf{R M}$ & SM & TM & UF & UM \\
\hline LOF high density (LFD) & & & & & 1 & 0 & 0.05 & 0 & 0 & 0 & 0 & 0 & 0 \\
\hline LOF low density (FLD) & & & & & & 1 & 0 & 0 & 0 & 0 & 0 & 0.05 & 0 \\
\hline LOF swamp (LOS) & & & & & & & 1 & 0 & 0 & 0 & 0 & 0 & 0 \\
\hline Rubber agroforest (RA) & & & & & & & & 1 & 0.24 & 0 & 0 & 0 & 0 \\
\hline Rubber monoculture (RM) & & & & & & & & & 1 & 0 & 0 & 0 & 0 \\
\hline Sengon monoculture (SM) & & & & & & & & & & 1 & 0 & 0 & 0 \\
\hline Teak monoculture (TM) & & & & & & & & & & & 1 & 0 & 0 \\
\hline Undisturbed forest (UF) & & & & & & & & & & & & 1 & 0 \\
\hline Undisturbed mangrove (UM) & & & & & & & & & & & & & 1 \\
\hline & & & & & Tree & & & & & & & & \\
\hline Acacia monoculture (AM) & 1 & 0 & 0 & 0 & 0.03 & 0 & 0.02 & 0 & 0 & 0.16 & 0 & 0 & 0 \\
\hline Fruit-based agroforest (FA) & & 1 & 0 & 0.27 & 0 & 0 & 0 & 0.01 & 0 & 0 & 0 & 0.01 & 0 \\
\hline Gmelina plantation (GP) & & & 1 & 0 & 0 & 0 & 0.01 & 0 & 0 & 0 & 0 & 0.02 & 0 \\
\hline Home garden (HG) & & & & 1 & 0.01 & 0 & 0 & 0.01 & 0 & 0 & 0.01 & 0.01 & 0 \\
\hline LOF high density (LFD) & & & & & 1 & 0.03 & 0.07 & 0 & 0 & 0 & 0 & 0.11 & 0 \\
\hline LOF low density (FLD) & & & & & & 1 & 0.01 & 0.06 & 0 & 0 & 0 & 0.02 & 0 \\
\hline LOF swamp (LOS) & & & & & & & 1 & 0 & 0 & 0 & 0 & 0.01 & 0 \\
\hline Rubber agroforest (RA) & & & & & & & & 1 & 0.49 & 0 & 0 & 0.01 & 0 \\
\hline Rubber monoculture (RM) & & & & & & & & & 1 & 0 & 0 & 0 & 0 \\
\hline Sengon monoculture (SM) & & & & & & & & & & 1 & 0 & 0 & 0 \\
\hline Teak monoculture (TM) & & & & & & & & & & & 1 & 0 & 0 \\
\hline Undisturbed forest (UF) & & & & & & & & & & & & 1 & 0 \\
\hline Undisturbed mangrove (UM) & & & & & & & & & & & & & 1 \\
\hline \multicolumn{14}{|c|}{ All growth stage } \\
\hline Acacia monoculture (AM) & 1 & 0.02 & 0 & 0 & 0.03 & 0 & 0.02 & 0 & 0 & 0.16 & 0 & 0 & 0 \\
\hline Fruit-based agroforest (FA) & & 1 & 0 & 0.20 & 0.02 & 0.01 & 0.04 & 0.01 & 0 & 0.02 & 0 & 0.01 & 0 \\
\hline Gmelina plantation (GP) & & & 1 & 0 & 0.01 & 0.01 & 0.06 & 0 & 0 & 0 & 0 & 0.02 & 0 \\
\hline Home garden (HG) & & & & 1 & 0.01 & 0 & 0 & 0.02 & 0 & 0 & 0.01 & 0.00 & 0 \\
\hline LOF high density (LFD) & & & & & 1 & 0.10 & 0.07 & 0.03 & 0 & 0.03 & 0 & 0.08 & 0 \\
\hline LOF low density (FLD) & & & & & & 1 & 0.04 & 0.08 & 0.02 & 0.02 & 0 & 0.01 & 0 \\
\hline LOF swamp (LOS) & & & & & & & 1 & 0 & 0.01 & 0.02 & 0 & 0.01 & 0 \\
\hline Rubber agroforest (RA) & & & & & & & & 1 & 0.63 & 0.00 & 0 & 0.01 & 0 \\
\hline Rubber monoculture (RM) & & & & & & & & & 1 & 0 & 0 & 0 & 0 \\
\hline Sengon monoculture (SM) & & & & & & & & & & 1 & 0 & 0.00 & 0 \\
\hline Teak monoculture (TM) & & & & & & & & & & & 1 & 0 & 0 \\
\hline Undisturbed forest (UF) & & & & & & & & & & & & 1 & 0 \\
\hline Undisturbed mangrove (UM) & & & & & & & & & & & & & 1 \\
\hline
\end{tabular}

Similarity index among land use systems in Pasir indicate dissimilar, except between rubber agroforest and rubber monoculture, even the similarity index is less than 0.5 for seedling, sapling, pole and tree stage. Tend to similar occurred between home garden and fruit-based systems. 
Table 7. Similarity matrix of species among land uses systems in each growth stage in Berau

\begin{tabular}{|c|c|c|c|c|c|c|c|c|c|c|c|}
\hline Land cover & CoA & DM & FA & GA & LHD & GP & PM & TA & TM & UF & UM \\
\hline \multicolumn{12}{|c|}{ Seedling } \\
\hline Coconut agroforest (CoA) & 1 & 0 & 0.01 & 0 & 0 & 0.11 & 0 & 0 & 0 & 0 & 0 \\
\hline Disturbed mangrove (DM) & & 1 & 0 & 0 & 0 & 0 & 0 & 0 & 0 & 0 & 0.20 \\
\hline Fruit-based agroforest (FA) & & & 1 & 0.03 & 0.04 & 0.16 & 0.04 & 0.05 & 0.03 & 0.00 & 0 \\
\hline Gaharu agroforest (GA) & & & & 1 & 0 & 0.04 & 0.22 & 0 & 0 & 0 & 0 \\
\hline Logged-over forest high density (LHD) & & & & & 1 & 0.07 & 0 & 0.02 & 0 & 0.16 & 0 \\
\hline Gmelina plantation (GP) & & & & & & 1 & 0.03 & 0.07 & 0 & 0 & 0 \\
\hline Pepper monoculture (PM) & & & & & & & 1 & 0 & 0.24 & 0 & 0 \\
\hline Teak agroforest (TA) & & & & & & & & 1 & 0.14 & 0 & 0 \\
\hline Teak monoculture (TM) & & & & & & & & & 1 & 0 & 0 \\
\hline Undisturbed forest (UF) & & & & & & & & & & 1 & 0 \\
\hline Undisturbed mangrove (UM) & & & & & & & & & & & 1 \\
\hline \multicolumn{12}{|c|}{ Sapling } \\
\hline Coconut agroforest (COA) & 1 & 0 & 0 & 0 & 0 & 0 & 0 & 0 & 0 & 0 & 0 \\
\hline Disturbed mangrove (DM) & & 1 & 0 & 0 & 0 & 0 & 0 & 0 & 0 & 0 & 0 \\
\hline Fruit-based agroforest (FA) & & & 1 & 0 & 0 & 0.15 & 0.07 & 0.38 & 0 & 0 & 0 \\
\hline Gaharu agroforest (GA) & & & & 1 & 0 & 0 & 0 & 0 & 0 & 0 & 0 \\
\hline Logged-over forest high density (LHD) & & & & & 1 & 0.04 & 0 & 0.04 & 0 & 0.15 & 0 \\
\hline Gmelina plantation (GP) & & & & & & 1 & 0 & 0.29 & 0 & 0 & 0 \\
\hline Pepper monoculture (PM) & & & & & & & 1 & 0 & 0 & 0 & 0 \\
\hline Teak agroforest (TA) & & & & & & & & 1 & 0 & 0 & 0 \\
\hline Teak monoculture (TM) & & & & & & & & & 1 & 0 & 0 \\
\hline Undisturbed forest (UF) & & & & & & & & & & 1 & 0 \\
\hline Undisturbed mangrove (UM) & & & & & & & & & & & 1 \\
\hline \multicolumn{12}{|l|}{ 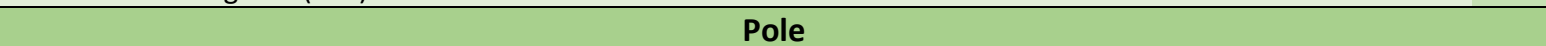 } \\
\hline Coconut agroforest (CoA) & 1 & 0 & 0 & 0 & 0 & 0 & 0 & 0 & 0 & 0 & 0 \\
\hline Disturbed mangrove (DM) & & 1 & 0 & 0 & 0 & 0 & 0 & 0 & 0 & 0 & 0 \\
\hline Fruit-based agroforest (FA) & & & 1 & 0.07 & 0 & 0 & 0 & 0.07 & 0 & 0.02 & 0 \\
\hline Gaharu agroforest (GA) & & & & 1 & 0 & 0 & 0 & 0 & 0 & 0 & 0 \\
\hline Logged-over forest high density (LHD) & & & & & 1 & 0 & 0 & 0 & 0 & 0.18 & 0 \\
\hline Gmelina plantation (GP) & & & & & & 1 & 0 & 0 & 0 & 0 & 0 \\
\hline Pepper monoculture (PM) & & & & & & & 1 & 0 & 0 & 0 & 0 \\
\hline Teak agroforest (TA) & & & & & & & & 1 & 0 & 0 & 0 \\
\hline Teak monoculture (TM) & & & & & & & & & 1 & 0 & 0 \\
\hline Undisturbed forest (UF) & & & & & & & & & & 1 & 0 \\
\hline Undisturbed mangrove (UM) & & & & & & & & & & & 1 \\
\hline \multicolumn{12}{|c|}{ Tree } \\
\hline Coconut agroforest (CoA) & 1 & 0 & 0.03 & 0.01 & 0 & 0 & 0 & 0 & 0 & 0 & 0 \\
\hline Disturbed mangrove (DM) & & 1 & 0 & 0 & 0 & 0 & 0 & 0 & 0 & 0 & 0.35 \\
\hline Fruit-based agroforest (FA) & & & 1 & 0.07 & 0.01 & 0.01 & 0.01 & 0.05 & 0.05 & 0.01 & 0 \\
\hline Gaharu agroforest (GA) & & & & 1 & 0 & 0 & 0 & 0 & 0 & 0 & 0 \\
\hline Logged-over forest high density (LHD) & & & & & 1 & 0.01 & 0 & 0.01 & 0 & 0.36 & 0 \\
\hline Gmelina plantation (GP) & & & & & & 1 & 0 & 0 & 0 & 0.01 & 0 \\
\hline Pepper monoculture (PM) & & & & & & & 1 & 0 & 0 & 0 & 0 \\
\hline Teak agroforest (TA) & & & & & & & & 1 & 0.76 & 0 & 0 \\
\hline Teak monoculture (TM) & & & & & & & & & 1 & 0 & 0 \\
\hline Undisturbed forest (UF) & & & & & & & & & & 1 & 0 \\
\hline Undisturbed mangrove (UM) & & & & & & & & & & & 1 \\
\hline \multicolumn{12}{|c|}{ All growth stage } \\
\hline Coconut agroforest (COA) & 1 & 0 & 0.02 & 0.01 & 0 & 0.02 & 0.01 & 0 & 0 & 0 & 0 \\
\hline Disturbed mangrove (DM) & & 1 & 0 & 0 & 0 & 0 & 0 & 0 & 0 & 0 & 0.36 \\
\hline Fruit-based agroforest (FA) & & & 1 & 0.06 & 0.02 & 0.03 & 0.01 & 0.07 & 0.04 & 0.01 & 0 \\
\hline Gaharu agroforest (GA) & & & & 1 & 0.00 & 0.00 & 0.01 & 0 & 0 & 0 & 0 \\
\hline Logged-over forest high density (LHD) & & & & & 1 & 0.04 & 0 & 0.01 & 0 & 0.37 & 0 \\
\hline Gmelina plantation (GP) & & & & & & 1 & 0.02 & 0.03 & 0.01 & 0.01 & 0 \\
\hline Pepper monoculture (PM) & & & & & & & 1 & 0 & 0.01 & 0.00 & 0 \\
\hline Teak agroforest (TA) & & & & & & & & 1 & 0.66 & 0.00 & 0 \\
\hline
\end{tabular}




\begin{tabular}{|c|c|c|c|c|c|c|c|c|c|c|c|}
\hline Land cover & CoA & DM & FA & GA & LHD & GP & PM & TA & TM & UF & UM \\
\hline Teak monoculture (TM) & & & & & & & & & 1 & 0.00 & 0 \\
\hline Undisturbed forest (UF) & & & & & & & & & & 1 & 0 \\
\hline Undisturbed mangrove (UM) & & & & & & & & & & & 1 \\
\hline
\end{tabular}

High similarity at tree stage found between teak agroforest and teak monoculture in Berau. Even at low index in tree stage, some species of undisturbed forest in Berau still found in logged-over forest. The same trend occurred between undisturbed mangrove and disturbed mangrove where low similarity found at seedling and tree stage.

\subsubsection{Tree diversity}

Tree diversity index in certain ecosystems express the complexity of species and population. Shannon-Wiener index used to express complexity species in various land use systems of Kutai Timur, Pasir and Berau (Table 8). High tree diversity index found in fruit-based agroforestry (Kutai Timur), undisturbed forest and logged-over forest (Pasir and Berau) above 3. Agroforestry systems in three districts commonly have medium tree diversity index at $1-3$, mostly less than 2 and monoculture systems categorized low tree diversity less than 1 .

Tree diversity index of vegetation growth stage express horizontal vertical composition of the ecosystem and indicate establishment period of the system and management practices applied in the systems. Tree diversity index among growth stage in fruit-based agroforestry is relatively constant. Low and medium intensive management such as rubber, cacao, teak, sengon and gmelina mostly have higher diversity at lower stages, but higher diversity index at higher growth stage found in undisturbed forest. Logged-over forest has various composition depend on the period after logging and logging practiced.

Table 8. Shannon-Wiener diversity index in various land cover systems for all growth stages in Kutai Timur, Pasir and Berau

\begin{tabular}{|c|c|c|c|c|c|c|c|}
\hline District & Land cover & No. of plot & Seedling & Sapling & Pole & Tree & $\begin{array}{l}\text { All growth } \\
\text { stage }\end{array}$ \\
\hline \multirow[t]{12}{*}{ Kutai Timur } & Logged-over forest low density & 2 & 1.63 & 2.45 & 2.46 & 1.84 & 2.44 \\
\hline & Undisturbed mangrove & 3 & 0.60 & 0.82 & 0 & 0.25 & 0.36 \\
\hline & Disturbed mangrove & 3 & 0.84 & 1.51 & 1.06 & 1.79 & 1.45 \\
\hline & Fruit-based agroforest & 4 & 3.09 & 2.86 & 2.38 & 3.09 & 3.56 \\
\hline & Teak agroforest & 1 & 2.08 & 1.33 & 0 & 1.48 & 1.92 \\
\hline & Rubber agroforest & 1 & 1.85 & 1.10 & 0 & 0.06 & 0.56 \\
\hline & Rubber monoculture & 2 & 0.69 & 0.56 & 0 & 0 & 0.06 \\
\hline & Coconut monoculture & 3 & 0.68 & 0.68 & 1.01 & 0.09 & 0.71 \\
\hline & Cacao monoculture & 3 & 1.43 & 0.90 & 0.34 & 0.93 & 1.20 \\
\hline & Citrus monoculture & 1 & 0.97 & 1.10 & 0.38 & 1.07 & 1.26 \\
\hline & Pepper agroforest & 1 & 0 & 0 & 0 & 0.23 & 0.23 \\
\hline & Gmelina plantation & 2 & 1.98 & 1.36 & 0.88 & 0.28 & 0.93 \\
\hline \multirow[t]{6}{*}{ Pasir } & Undisturbed forest & 2 & 2.42 & 2.59 & 3.09 & 3.82 & 3.83 \\
\hline & Logged-over forest high density & 1 & 1.71 & 2.39 & 2.20 & 3.47 & 3.73 \\
\hline & Logged-over forest low density & 1 & 1.73 & 1.33 & 2.14 & 2.63 & 3.03 \\
\hline & Logged-over swamp forest & 2 & 1.77 & 1.91 & 2.06 & 1.80 & 2.30 \\
\hline & Fruit-based agroforest & 2 & 1.84 & 1.04 & 1.33 & 1.84 & 2.49 \\
\hline & Undisturbed mangrove & 2 & 0.95 & 0.69 & 0.92 & 0.55 & 0.78 \\
\hline
\end{tabular}




\begin{tabular}{|c|c|c|c|c|c|c|c|}
\hline District & Land cover & No. of plot & Seedling & Sapling & Pole & Tree & $\begin{array}{l}\text { All growth } \\
\text { stage }\end{array}$ \\
\hline & Home garden & 1 & 0 & 0 & 1.10 & 1.65 & 1.80 \\
\hline & Rubber agroforest & 1 & 2.29 & 1.05 & 0.88 & 0.78 & 1.26 \\
\hline & Rubber monoculture & 1 & 0.64 & 0.41 & 0 & 0 & 0.12 \\
\hline & Teak monoculture & 1 & 0.56 & 0 & 0 & 0 & 0.04 \\
\hline & Acacia monoculture & 1 & 0 & 0 & 0 & 0.13 & 0.13 \\
\hline & Sengon monoculture & 1 & 1.84 & 1.28 & 0.41 & 0.37 & 0.85 \\
\hline & Gmelina plantation & 1 & 1.31 & 1.78 & 1.89 & 0.71 & 1.26 \\
\hline \multirow[t]{11}{*}{ Berau } & Undisturbed forest & 2 & 2.54 & 2.89 & 2.74 & 3.25 & 3.47 \\
\hline & Logged-over forest high density & 3 & 3.39 & 3.19 & 2.91 & 4.04 & 4.20 \\
\hline & Undisturbed mangrove & 2 & 0.45 & 0.45 & 0 & 0.60 & 0.56 \\
\hline & Disturbed mangrove & 1 & 0 & 0 & 0 & 0 & 0 \\
\hline & Fruit-based agroforest & 11 & 2.88 & 2.40 & 1.42 & 2.10 & 2.48 \\
\hline & Gaharu agroforest & 1 & 0.69 & 0 & 1.05 & 0.94 & 1.03 \\
\hline & Coconut agroforest & 1 & 0.64 & 0 & 0 & 0.92 & 1.23 \\
\hline & Pepper agroforest & 2 & 1.73 & 0.80 & 0.64 & 0.45 & 0.72 \\
\hline & Teak agroforest & 1 & 1.33 & 0.56 & 0.64 & 0.07 & 0.72 \\
\hline & Teak monoculture & 1 & 1.04 & 0 & 0 & 0 & 0.24 \\
\hline & Gmelina plantation & 3 & 2.32 & 2.11 & 1.62 & 0.69 & 1.59 \\
\hline
\end{tabular}

\subsubsection{Above-ground carbon stock}

Similar to the other sample area, undisturbed forest of low land forest in Berau and Pasir has highest carbon stock above $200 \mathrm{Mg} \mathrm{ha}^{-1}$, followed by undisturbed mangrove about $180 \mathrm{Mg} \mathrm{ha}^{-1}$. Logged-over forest has low density and high density has about $60 \mathrm{Mg} \mathrm{ha}^{-1}$ and $180 \mathrm{Mg} \mathrm{ha}^{-1}$, respectively. Manmade ecosystems, both monoculture and agroforest has various value of carbon stock depend on the species integrated in the system (Tabel 9).

Table 9. Above-ground carbon stock of four carbon pool and total carbon stock in various land use types in Kutai Timur, Pasir and Berau District

\begin{tabular}{|c|c|c|c|c|c|c|c|}
\hline \multirow[t]{2}{*}{ District } & \multirow[t]{2}{*}{ Land cover } & \multirow{2}{*}{$\begin{array}{l}\text { Number } \\
\text { of plot }\end{array}$} & \multicolumn{5}{|c|}{ Carbon stock (Mg ha-1) } \\
\hline & & & Tree & Necromass & Understorey & Litter & Total \\
\hline Kutai & Logged-over forest low density & 2 & 37.0 & 0.9 & 1.7 & 20.4 & 60.0 \\
\hline \multirow[t]{10}{*}{ Timur } & Undisturbed mangrove & 3 & 167.7 & 5.6 & 0 & 0 & 173.3 \\
\hline & Disturbed mangrove & 3 & 16.2 & 14.4 & 0.5 & 1.7 & 32.7 \\
\hline & Fruit-based agroforest & 4 & 86.8 & 14.0 & 3.1 & 11.1 & 114.9 \\
\hline & Teak agroforest & 1 & 127.6 & 0 & 0 & 0 & 127.6 \\
\hline & Rubber monoculture & 3 & 54.8 & 3.8 & 2.0 & 13.8 & 74.3 \\
\hline & Coconut monoculture & 3 & 49.9 & 0 & 3.0 & 3.7 & 56.7 \\
\hline & Cacao monoculture & 3 & 34.1 & 1.3 & 0.8 & 19.1 & 55.2 \\
\hline & Citrus monoculture & 1 & 6.3 & 0.1 & 5.1 & 0 & 11.5 \\
\hline & Pepper agroforest ${ }^{\star}$ & 1 & 38.2 & 0 & 0.2 & 3.3 & 41.7 \\
\hline & Gmelina plantation & 2 & 43.1 & 10.9 & 11.8 & 13.8 & 79.6 \\
\hline \multirow[t]{7}{*}{ Pasir } & Undisturbed forest & 2 & 277.9 & 46.1 & 5.3 & 0.3 & 329.5 \\
\hline & Logged-over forest high density & 1 & 166.6 & 18.2 & 12.5 & 0.1 & 197.4 \\
\hline & Logged-over forest low density & 1 & 44.7 & 13.4 & 4.9 & 0.3 & 63.4 \\
\hline & Logged-over swamp forest & 2 & 61.3 & 2.3 & 2.6 & 1.6 & 67.8 \\
\hline & Fruit-based agroforest & 2 & 76.2 & 0 & 8.4 & 0.3 & 84.8 \\
\hline & Undisturbed mangrove & 1 & 161.7 & 16.7 & 1.9 & 0.8 & 181.1 \\
\hline & Home garden & 1 & 21.6 & 3.7 & 7.5 & 2.7 & 35.6 \\
\hline
\end{tabular}




\begin{tabular}{llrrrrrr}
\hline District & \multicolumn{1}{c}{ Land cover } & Number & \multicolumn{5}{c}{ Carbon stock (Mg ha ${ }^{-1}$ ) } \\
\cline { 5 - 8 } & of plot & Tree & Necromass & Understorey & Litter & \multicolumn{1}{c}{ Total } \\
\cline { 5 - 8 } & Rubber agroforest & 1 & 101.2 & 8.3 & 7.5 & 0.3 & 117.4 \\
& Rubber monoculture (young age) & 1 & 8.8 & 0 & 2.2 & 0.2 & 11.2 \\
& Teak monoculture & 1 & 48.7 & 0 & 2.6 & 0.3 & 51.7 \\
& Acacia monoculture & 1 & 71.2 & 0.4 & 1.3 & 0 & 72.9 \\
& Gmelina plantation & 1 & 50.6 & 0 & 1.6 & 0 & 52.2 \\
\hline Berau & Undisturbed forest & 2 & 192.3 & 2.3 & 0.1 & 15.3 & 210.5 \\
& Logged-over forest high density & 3 & 143.6 & 1.6 & 0.6 & 12.2 & 158.0 \\
& Undisturbed mangrove & 3 & 187.3 & 0.3 & 0 & 0 & 187.6 \\
& Fruit-based agroforest & 11 & 58.9 & 2.1 & 0.3 & 6.8 & 68.1 \\
& Coconut agroforest & 1 & 45.7 & 0 & 0.4 & 2.1 & 48.21 \\
& Pepper agroforest & 2 & 29.4 & 0 & 1.3 & 2.1 & 32.7 \\
& Teak agroforest & 2 & 62.9 & 0 & 0.3 & 7.4 & 70.7 \\
& Gmelina plantation & 2 & 33.6 & 0 & 0.2 & 3.4 & 37.2 \\
& Sengon monoculture & 1 & 24.3 & 1.1 & 1.0 & 4.5 & 30.9 \\
\hline
\end{tabular}

\section{Discussions}

\subsection{Tree species component}

More intensive management and establishment period of the systems affect to species richness significantly. However, the real monoculture system with single species in smallholder, both plot and landscape level is very rare. In the beginning, monoculture systems developed for single species, such as rubber, teak, gmelina, sengon and acacia but wild species regenerated in system due to irregularly management or even planted by the owner. Improved diversity in such situations is attributed to species resilience to regenerate or to other factors such as canopy gap formation that increased light to the forest floor (Senbeta et al 2002) led the fast growing species to grow.

Fruit-based agroforestry, a traditional systems practiced by local community, such as Dayak tribe consist high species richness for all growth stage. This is indicates that this systems was established for long period where some species grow up to tree level and low management to be implemented. Low management practiced, such as irregular weeding or even no weeding provides some tree species regenerated naturally and affect to constant diversity index for seedling and sapling. Low disturbance may occur in fruit-based agroforestry system managed by local community, since they have other land-based livelihood option such as rubber monoculture and annual crop.

Low species richness and diversity in mangrove, both undisturbed and disturbed because of specific land character that only certain species can adapt to the typical land cover. Mangrove tree species is determined by the type of substrate and the zonation of the mangrove ecosystem that usually harbouring only few tree species (Alongi 2012).

The lower species richness and diversity at younger growth stage occurred in undisturbed forest due to canopy closure that only certain species can adapt. In the logged-over forest, lower species richness and diversity at sapling and pole stages assumed caused by clearing for pathway or impact of logging activity. The factor also can be caused by species specific character in the way of sprouting its seeds but some species cannot survive until sapling stage. While in man-made land cover, the proportion of 
seedling and sapling tends to be influenced by land management. More intensive management availability of seedling and sapling is low.

Dominance of Dipterocarpaceae such as Shorea and Dipterocarpus in undisturbed forest of Pasir District where located in Hutan Lindung Gunung Lumut indicate that the area is well protected. As well as, dominance of ulin (Eusideroxylon zwageri) in logged-over forest of Berau where located in ecotourism area of forest park. Both, Dipterocarp timber and ulin are high value timber. Dominance pioneer species in logged-over forest low density indicates that forest disturbance may occur at less than 10 years, but sub-climax species dominated logged-over forest high density shown that the ecosystems disturbance occurred, but in low level.

Dominance species is an indicator of composition in a certain habitat (Lohbeck et al 2014), that refers to its relative importance in its habitat ecologically (Chase et al 2003). In the natural regeneration, dominance species may useful to identify the disturbance level, both of frequency and intensity. In the man-made ecosystems, dominance of certain species can be used to identify or classify the ecological type, as well as to understand the establishment purposes and management practices. Current dominance species is considerate as basic information to determine land management action.

Typical natural land cover such mangrove tend to dominated by single species due to the characteristic of mangrove zonation. Sonneratia and Avicennia commonly co-dominant in exposed mangrove zone, whrere grows on the seaward side of mangrove belts and inundated by medium high tides (van Steenis 1958). Sonneratia alba and Avicennia alba co-dominate in this deeply inundated coastal zone. Sonneratia alba tends to dominant on sands, or on corals, while in the muddy substrate tend to dominated by Rhizophora species (Giesen et al 2007).

Dominant species in natural ecosystem not exactly similar among growth stage, because in natural ecosystems normally there is no single dominant species (Leigh 2004), hundreds species shared the area each other. In man-made ecosystem, similarity among growth stage is strongly determined by anthropological factor, such as management practices in the systems. Management practiced directly impact to availability natural regeneration species developed in the systems. Low intensive management systems still support natural regeneration species, such as mixed agroforest system like Shorea agroforest system in Krui, Lampung (de Foresta et al 2000).

\subsection{Above-ground carbon stock}

Undisturbed forest in East Kalimantan, generally has high carbon stock above $200 \mathrm{Mg} \mathrm{ha}^{-1}$, due to presence of larger trees. Carbon stock in logged-over forest is ranged $60-200 \mathrm{Mg} \mathrm{ha}^{-1}$ depend on tree density and presence of larger tree. Larger tree in logged-over forest high density contribute to high carbon content. Logged-over forest low density dominated by shrub and smaller tree less than $10 \mathrm{~cm}$ diameter has lower carbon stock. Tree based systems have varied carbon content depend on the main species and establishment period (age of tree), since tree species contribute up to $80 \%$ of carbon stock. Capability of trees on absorbing carbon from atmosphere which is substantial amount is stored in mature trees (Meineke et al 2016). Fruit-based agroforestry system practiced by local community has carbon stock similar to logged over forest high density above $100 \mathrm{Mg} \mathrm{ha}^{-1}$. Long establish of this system provides chance to fruit trees species stay in the land, and the owner tend to keep as source of income. 
Monoculture systems that develop widely in three districts such as perennial crop of cacao, coconut, pepper and rubber has lower carbon stock about $30-70 \mathrm{Mg} \mathrm{ha}^{-1}$, as well as industrial timber such as gmelina, teak and sengon.

\section{Conclusions}

Higher tree species richness and diversity found in natural ecosystems such as undisturbed forest, logged-over forest, except mangrove that only few species owing to specific characteristic on the ecosystem where allowed limited species to grow. Monoculture systems commonly hold less tree species in the systems depend on the management. Low intensive management contains higher tree species richness and diversity.

In line with species richness and diversity, natural ecosystems of undisturbed forest, logged-over forest and low intensive management of fruit-based agroforest consist of higher carbon stock than monoculture systems.

\section{Reference}

Alongi DM. 2012. Carbon sequestration in mangrove forests. Carbon Management (2012) 3(3), 313-322

Chase JM, Leibold MA. 2003. Ecological Niches: Linking Classical and Contemporary Approaches. University of Chicago Press, Chicago. http://dx.doi.org/10.7208/chicago/9780226101811.001.0001

Chave J, Andalo C, Brown S, Cairns MA, Chambers JQ, et al. 2005. Tree allometry and improxed estimation of carbon stocks and balance in tropical forests. Oecologia 145:87-99. DOI 10.1007/s00442-005-0100-x.

Colwell RK. 2009. Biodiversity: Concepts, Patterns and Measurement. In Simon A. L. The Princeton Guide to Ecology. Princeton: Princeton University Press. pp. 257-263.

Curtis JT, McIntosh RP. 1950. The interrelations of certain analytic and synthetic phytosociological characters. Ecology 31: 434-455.

Delmy A. 2001. Fire resistance of tree species in Bukit Soeharto Education Forest, East Kalimantan, Indonesia. In S. Kobayasi, et al, Eds. Rehabilitation of Degraded Tropical Forest Ecosystems. Workshop Proceeding 2-4 November 1999. Bogor: Centre for International Forestry Research.

GE-LAMA-I. 2016. Project Background. Retrieved from http://www.gelamai.org/en/about/background

Giesen W, Wulffraat S, Zieren M, Scholten L. 2007. Mangrove guidebook for south east asia, ISBN: 974-794685-8, FAO and Wetlands International, Bangkok.

de Foresta H, Kusworo A, Michon G, Djatmiko WA. 2000. Ketika kebun berupa hutan - Agroforest khas Indonesia - Sumbangan masyarakat bagi pembangunan berkelanjutan. International Centre for Research in Agroforestry, Bogor, Indonesia; Institut de Recherche pour le Développement, France; dan Ford Foundation, Jakarta, Indonesia.

Hairiah K, Dewi S, Agus F, Velarde S, Ekadinata A, et al. 2011. Measuring Carbon Stocks Across Land Use Systems: A Manual. Bogor, Indonesia: World Agroforestry Centre (ICRAF), SEA Regional Office, 154 pp.

Harris NL, Brown S, Hagen SC, Saatchi SS, Petrova S, et al. 2012. Baseline map of carbon emissions from deforestation in tropical regions. Science 336: 1573-1576.

Kartawinata K, Purwaningsih, Partomihardjo T,Yusuf R, Abdulhadi R, Riswan S. 2008. Floristic and a structure of low land Dipterocarp forest at Wanariset Samboja, East Kalimantan, Indonesia. Reinwartia, 12(4), 301-323. 
Leigh D, Puyravaud D, Terborgh S, Wright SJ, et al. 2004. Why Do Some Tropical Forests Have So Many Species of Trees? Biotropica, 36, 447-473.

Lohbeck M, Poorter L, Martínez-Ramos M, Rodriguez-Velázquez J, van Breugel, M et al. 2014. Changing Drivers of Species Dominance during Tropical Forest Succession. Functional Ecology, 28, 1052-1058. http://dx.doi.org/10.1111/1365-2435.12240

Meineke E, Youngsteadt E, Dunn RR, Frank SD. 2016. Urban warming reduces aboveground carbon storage. Proc. R. Soc. B 283: 20161574. http://dx.doi.org/10.1098/rspb.2016.1574

Senbeta F, Teketay D, Näslund B-A. 2002. Native woody species regeneration in exotic tree plantations at Munessa-Shashemene forest, Southern Ethiopia. New Forests, 24: 131-145.

van Steenis CGGJ. 1958. Ecology of mangroves. Introduction to account of the Rhizophoraceae by Ding Hou, Flora Malesiana, Ser. I. 



\section{WORKING PAPERS WITH DOIs}

2005

1. Agroforestry in the drylands of eastern Africa: a call to action

2. Biodiversity conservation through agroforestry: managing tree species diversity within a network of community-based, nongovernmental, governmental and research organizations in western Kenya.

3. Invasion of prosopis juliflora and local livelihoods: Case study from the Lake Baringo area of Kenya

4. Leadership for change in farmers organizations: Training report: Ridar Hotel, Kampala, 29th March to 2nd April 2005.

5. Domestication des espèces agroforestières au Sahel : situation actuelle et perspectives

6. Relevé des données de biodiversité ligneuse: Manuel du projet biodiversité des parcs agroforestiers au Sahel

7. Improved land management in the Lake Victoria Basin: TransVic Project's draft report.

8. Livelihood capital, strategies and outcomes in the Taita hills of Kenya

9. Les espèces ligneuses et leurs usages: Les préférences des paysans dans le Cercle de Ségou, au Mali

10. La biodiversité des espèces ligneuses: Diversité arborée et unités de gestion du terroir dans le Cercle de Ségou, au Mali

\section{6}

11. Bird diversity and land use on the slopes of Mt. Kilimanjaro and the adjacent plains, Tanzania

12. Water, women and local social organization in the Western Kenya Highlands

13. Highlights of ongoing research of the World Agroforestry Centre in Indonesia

14. Prospects of adoption of tree-based systems in a rural landscape and its likely impacts on carbon stocks and farmers' welfare: The FALLOW Model Application in Muara Sungkai, Lampung, Sumatra, in a 'Clean Development Mechanism' context

15. Equipping integrated natural resource managers for healthy Agroforestry landscapes.

17. Agro-biodiversity and CGIAR tree and forest science: approaches and examples from Sumatra.

18. Improving land management in eastern and southern Africa: A review of policies.

19. Farm and household economic study of Kecamatan Nanggung, Kabupaten Bogor, Indonesia: A socio-economic base line study of Agroforestry innovations and livelihood enhancement.

20. Lessons from eastern Africa's unsustainable charcoal business.

21. Evolution of RELMA's approaches to land management: Lessons from two decades of research and development in eastern and southern Africa

22. Participatory watershed management: Lessons from RELMA's work with farmers in eastern Africa.

23. Strengthening farmers' organizations: The experience of RELMA and ULAMP.

24. Promoting rainwater harvesting in eastern and southern Africa.

25. The role of livestock in integrated land management.

26. Status of carbon sequestration projects in Africa: Potential benefits and challenges to scaling up. 
27. Social and Environmental Trade-Offs in Tree Species Selection: A Methodology for Identifying Niche Incompatibilities in Agroforestry [Appears as AHI Working Paper no. 9]

28. Managing tradeoffs in agroforestry: From conflict to collaboration in natural resource management. [Appears as AHI Working Paper no. 10]

29. Essai d'analyse de la prise en compte des systemes agroforestiers pa les legislations forestieres au Sahel: Cas du Burkina Faso, du Mali, du Niger et du Senegal.

30. Etat de la recherche agroforestière au Rwanda etude bibliographique, période 1987-2003

2007

31. Science and technological innovations for improving soil fertility and management in Africa: A report for NEPAD's Science and Technology Forum.

32. Compensation and rewards for environmental services.

33. Latin American regional workshop report compensation.

34. Asia regional workshop on compensation ecosystem services.

35. Report of African regional workshop on compensation ecosystem services.

36. Exploring the inter-linkages among and between compensation and rewards for ecosystem services CRES and human well-being

37. Criteria and indicators for environmental service compensation and reward mechanisms: realistic, voluntary, conditional and pro-poor

38. The conditions for effective mechanisms of compensation and rewards for environmental services.

39. Organization and governance for fostering Pro-Poor Compensation for Environmental Services.

40. How important are different types of compensation and reward mechanisms shaping poverty and ecosystem services across Africa, Asia \& Latin America over the Next two decades?

41. Risk mitigation in contract farming: The case of poultry, cotton, woodfuel and cereals in East Africa.

42. The RELMA savings and credit experiences: Sowing the seed of sustainability

43. Yatich J., Policy and institutional context for NRM in Kenya: Challenges and opportunities for Landcare.

44. Nina-Nina Adoung Nasional di So! Field test of rapid land tenure assessment (RATA) in the Batang Toru Watershed, North Sumatera.

45. Is Hutan Tanaman Rakyat a new paradigm in community based tree planting in Indonesia?

46. Socio-Economic aspects of brackish water aquaculture (Tambak) production in Nanggroe Aceh Darrusalam.

47. Farmer livelihoods in the humid forest and moist savannah zones of Cameroon.

48. Domestication, genre et vulnérabilité : Participation des femmes, des Jeunes et des catégories les plus pauvres à la domestication des arbres agroforestiers au Cameroun.

49. Land tenure and management in the districts around Mt Elgon: An assessment presented to the Mt Elgon ecosystem conservation programme.

50. The production and marketing of leaf meal from fodder shrubs in Tanga, Tanzania: A pro-poor enterprise for improving livestock productivity.

51. Buyers Perspective on Environmental Services (ES) and Commoditization as an approach to liberate ES markets in the Philippines. 
52. Towards Towards community-driven conservation in southwest China: Reconciling state and local perceptions.

53. Biofuels in China: An Analysis of the Opportunities and Challenges of Jatropha curcas in Southwest China.

54. Jatropha curcas biodiesel production in Kenya: Economics and potential value chain development for smallholder farmers

55. Livelihoods and Forest Resources in Aceh and Nias for a Sustainable Forest Resource Management and Economic Progress

56. Agroforestry on the interface of Orangutan Conservation and Sustainable Livelihoods in Batang Toru, North Sumatra.

2008

57. Assessing Hydrological Situation of Kapuas Hulu Basin, Kapuas Hulu Regency, West Kalimantan.

58. Assessing the Hydrological Situation of Talau Watershed, Belu Regency, East Nusa Tenggara.

59. Kajian Kondisi Hidrologis DAS Talau, Kabupaten Belu, Nusa Tenggara Timur.

60. Kajian Kondisi Hidrologis DAS Kapuas Hulu, Kabupaten Kapuas Hulu, Kalimantan Barat.

61. Lessons learned from community capacity building activities to support agroforest as sustainable economic alternatives in Batang Toru orang utan habitat conservation program (Martini, Endri et al.)

62. Mainstreaming Climate Change in the Philippines.

63. A Conjoint Analysis of Farmer Preferences for Community Forestry Contracts in the Sumber Jaya Watershed, Indonesia.

64. The highlands: a shared water tower in a changing climate and changing Asia

65. Eco-Certification: Can It Deliver Conservation and Development in the Tropics.

66. Designing ecological and biodiversity sampling strategies. Towards mainstreaming climate change in grassland management.

67. Towards mainstreaming climate change in grassland management policies and practices on the Tibetan Plateau

68. An Assessment of the Potential for Carbon Finance in Rangelands

69 ECA Trade-offs Among Ecosystem Services in the Lake Victoria Basin.

69. The last remnants of mega biodiversity in West Java and Banten: an in-depth exploration of RaTA (Rapid Land Tenure Assessment) in Mount Halimun-Salak National Park Indonesia

70. Le business plan d'une petite entreprise rurale de production et de commercialisation des plants des arbres locaux. Cas de quatre pépinières rurales au Cameroun.

71. Les unités de transformation des produits forestiers non ligneux alimentaires au Cameroun. Diagnostic technique et stratégie de développement Honoré Tabuna et Ingratia Kayitavu.

72. Les exportateurs camerounais de safou (Dacryodes edulis) sur le marché sous régional et international. Profil, fonctionnement et stratégies de développement.

73. Impact of the Southeast Asian Network for Agroforestry Education (SEANAFE) on agroforestry education capacity.

74. Setting landscape conservation targets and promoting them through compatible land use in the Philippines.

75. Review of methods for researching multistrata systems. 
76. Study on economical viability of Jatropha curcas L. plantations in Northern Tanzania assessing farmers' prospects via cost-benefit analysis

77. Cooperation in Agroforestry between Ministry of Forestry of Indonesia and International Center for Research in Agroforestry

78. "China's bioenergy future. an analysis through the Lens if Yunnan Province

79. Land tenure and agricultural productivity in Africa: A comparative analysis of the economics literature and recent policy strategies and reforms

80. Boundary organizations, objects and agents: linking knowledge with action in Agroforestry watersheds

81. Reducing emissions from deforestation and forest degradation (REDD) in Indonesia: options and challenges for fair and efficient payment distribution mechanisms

2009

82. Mainstreaming climate change into agricultural education: challenges and perspectives

83. Challenging conventional mindsets and disconnects in conservation: the emerging role of ecoagriculture in Kenya's landscape mosaics

84. Lesson learned RATA garut dan bengkunat: suatu upaya membedah kebijakan pelepasan kawasan hutan dan redistribusi tanah bekas kawasan hutan

85. The emergence of forest land redistribution in Indonesia

86. Commercial opportunities for fruit in Malawi

87. Status of fruit production processing and marketing in Malawi

88. Fraud in tree science

89. Trees on farm: analysis of global extent and geographical patterns of agroforestry

90. The springs of Nyando: water, social organization and livelihoods in Western Kenya

91. Building capacity toward region-wide curriculum and teaching materials development in agroforestry education in Southeast Asia

92. Overview of biomass energy technology in rural Yunnan (Chinese - English abstract)

93. A pro-growth pathway for reducing net GHG emissions in China

94. Analysis of local livelihoods from past to present in the central Kalimantan Ex-Mega Rice Project area

95. Constraints and options to enhancing production of high quality feeds in dairy production in Kenya, Uganda and Rwanda

2010

96. Agroforestry education in the Philippines: status report from the Southeast Asian Network for Agroforestry Education (SEANAFE)

97. Economic viability of Jatropha curcas L. plantations in Northern Tanzania- assessing farmers' prospects via cost-benefit analysis.

98. Hot spot of emission and confusion: land tenure insecurity, contested policies and competing claims in the central Kalimantan Ex-Mega Rice Project area

99. Agroforestry competences and human resources needs in the Philippines

100. CES/COS/CIS paradigms for compensation and rewards to enhance environmental Services 
101. Case study approach to region-wide curriculum and teaching materials development in agroforestry education in Southeast Asia

102. Stewardship agreement to reduce emissions from deforestation and degradation (REDD): Lubuk Beringin's Hutan Desa as the first village forest in Indonesia

103. Landscape dynamics over time and space from ecological perspective

104. Komoditisasi atau koinvestasi jasa lingkungan: skema imbal jasa lingkungan program peduli sungai di DAS Way Besai, Lampung, Indonesia

105. Improving smallholders' rubber quality in Lubuk Beringin, Bungo district, Jambi province, Indonesia: an initial analysis of the financial and social benefits

106. Rapid Carbon Stock Appraisal (RACSA) in Kalahan, Nueva Vizcaya, Philippines

107. Tree domestication by ICRAF and partners in the Peruvian Amazon: lessons learned and future prospects in the domain of the Amazon Initiative eco-regional program

108. Memorias del Taller Nacional: "Iniciativas para Reducir la Deforestación en la region Andino Amazónica", 09 de Abril del 2010. Proyecto REALU Peru

109. Percepciones sobre la Equidad y Eficiencia en la cadena de valor de REDD en Perú -Reporte de Talleres en Ucayali, San Martín y Loreto, 2009. Proyecto REALU-Perú.

110. Reducción de emisiones de todos los Usos del Suelo. Reporte del Proyecto REALU Perú Fase 1

111. Programa Alternativas a la Tumba-y-Quema (ASB) en el Perú. Informe Resumen y Síntesis de la Fase II. 2da. versión revisada

112. Estudio de las cadenas de abastecimiento de germoplasma forestal en la amazonía Boliviana

113. Biodiesel in the Amazon

114. Estudio de mercado de semillas forestales en la amazonía Colombiana

115. Estudio de las cadenas de abastecimiento de germoplasma forestal en Ecuador http://dx.doi.org10.5716/WP10340.PDF

116. How can systems thinking, social capital and social network analysis help programs achieve impact at scale?

117. Energy policies, forests and local communities in the Ucayali Region, Peruvian Amazon

118. NTFPs as a Source of Livelihood Diversification for Local Communities in the Batang Toru Orangutan Conservation Program

119. Studi Biodiversitas: Apakah agroforestry mampu mengkonservasi keanekaragaman hayati di DAS Konto?

120. Estimasi Karbon Tersimpan di Lahan-lahan Pertanian di DAS Konto, Jawa Timur

121. Implementasi Kaji Cepat Hidrologi (RHA) di Hulu DAS Brantas, Jawa Timur. http://dx.doi.org/10.5716/WP10338.PDF

122. Kaji Cepat Hidrologi di Daerah Aliran Sungai Krueng Peusangan, NAD,Sumatra http://dx.doi.org/10.5716/WP10337.PDF

123. A Study of Rapid Hydrological Appraisal in the Krueng Peusangan Watershed, NAD, Sumatra. http://dx.doi.org/10.5716/WP10339.PDF

2011

124. An Assessment of farm timber value chains in Mt Kenya area, Kenya

125. A Comparative financial analysis of current land use systems and implications for the adoption of improved agroforestry in the East Usambaras, Tanzania

126. Agricultural monitoring and evaluation systems 
127. Challenges and opportunities for collaborative landscape governance in the East Usambara Mountains, Tanzania

128. Transforming Knowledge to Enhance Integrated Natural Resource Management Research, Development and Advocacy in the Highlands of Eastern Africa http://dx.doi.org/10.5716/WP11084.PDF

129. Carbon-forestry projects in the Philippines: potential and challenges The Mt Kitanglad Range forest-carbon development http://dx.doi.org10.5716/WP11054.PDF

130. Carbon forestry projects in the Philippines: potential and challenges. The Arakan Forest Corridor forest-carbon project. http://dx.doi.org10.5716/WP11055.PDF

131. Carbon-forestry projects in the Philippines: potential and challenges. The Laguna Lake Development Authority's forest-carbon development project. http://dx.doi.org/10.5716/WP11056.PDF

132. Carbon-forestry projects in the Philippines: potential and challenges. The Quirino forest-carbon development project in Sierra Madre Biodiversity Corridor http://dx.doi.org10.5716/WP11057.PDF

133. Carbon-forestry projects in the Philippines: potential and challenges. The Ikalahan Ancestral Domain forest-carbon development http://dx.doi.org10.5716/WP11058.PDF

134. The Importance of Local Traditional Institutions in the Management of Natural Resources in the Highlands of Eastern Africa. http://dx.doi.org/10.5716/WP11085.PDF

135. Socio-economic assessment of irrigation pilot projects in Rwanda. http://dx.doi.org/10.5716/WP11086.PDF

136. Performance of three rambutan varieties (Nephelium lappaceum L.) on various nursery media. http://dx.doi.org/10.5716/WP11232.PDF

137. Climate change adaptation and social protection in agroforestry systems: enhancing adaptive capacity and minimizing risk of drought in Zambia and Honduras http://dx.doi.org/10.5716/WP11269.PDF

138. Does value chain development contribute to rural poverty reduction? Evidence of asset building by smallholder coffee producers in Nicaragua http://dx.doi.org/10.5716/WP11271.PDF

139. Potential for biofuel feedstock in Kenya. http://dx.doi.org/10.5716/WP11272.PDF

140. Impact of fertilizer trees on maize production and food security in six districts of Malawi. http://dx.doi.org/10.5716/WP11281.PDF

2012

141. Fortalecimiento de capacidades para la gestión del Santuario Nacional Pampa Hermosa: Construyendo las bases para un manejo adaptativo para el desarrollo local. Memorias del Proyecto. http://dx.doi.org/10.5716/WP12005.PDF

142. Understanding rural institutional strengthening: A cross-level policy and institutional framework for sustainable development in Kenya http://dx.doi.org/10.5716/WP12012.PDF

143. Climate change vulnerability of agroforestry http://dx.doi.org/10.5716/WP16722.PDF

144. Rapid assesment of the inner Niger delta of Mali http://dx.doi.org/10.5716/WP12021.PDF

145. Designing an incentive program to reduce on-farm deforestationin the East Usambara Mountains, Tanzania http://dx.doi.org/10.5716/WP12048.PDF

146. Extent of adoption of conservation agriculture and agroforestry in Africa: the case of Tanzania, Kenya, Ghana, and Zambia http://dx.doi.org/10.5716/WP12049.PDF 
147. Policy incentives for scaling up conservation agriculture with trees in Africa: the case of Tanzania, Kenya, Ghana and Zambia http://dx.doi.org/10.5716/WP12050.PDF

148. Commoditized or co-invested environmental services? Rewards for environmental services scheme: River Care program Way Besai watershed, Lampung, Indonesia.

http://dx.doi.org/10.5716/WP12051.PDF

149. Assessment of the headwaters of the Blue Nile in Ethiopia. http://dx.doi.org/10.5716/WP12160.PDF

150. Assessment of the uThukela Watershed, Kwazaulu. http://dx.doi.org/10.5716/WP12161.PDF

151. Assessment of the Oum Zessar Watershed of Tunisia. http://dx.doi.org/10.5716/WP12162.PDF

152. Assessment of the Ruwenzori Mountains in Uganda. http://dx.doi.org/10.5716/WP12163.PDF

153. History of agroforestry research and development in Viet Nam. Analysis of research opportunities and gaps. http://dx.doi.org/10.5716/WP12052.PDF

154. REDD+ in Indonesia: a Historical Perspective. http://dx.doi.org/10.5716/WP12053.PDF

155. Agroforestry and Forestry in Sulawesi series: Livelihood strategies and land use system dynamics in South Sulawesi http://dx.doi.org/10.5716/WP12054.PDF

156. Agroforestry and Forestry in Sulawesi series: Livelihood strategies and land use system dynamics in Southeast Sulawesi. http://dx.doi.org/10.5716/WP12055.PDF

157. Agroforestry and Forestry in Sulawesi series: Profitability and land-use systems in South and Southeast Sulawesi. http://dx.doi.org/10.5716/WP12056.PDF

158. Agroforestry and Forestry in Sulawesi series: Gender, livelihoods and land in South and Southeast Sulawesi http://dx.doi.org/10.5716/WP12057.PDF

159. Agroforestry and Forestry in Sulawesi series: Agroforestry extension needs at the community level in AgFor project sites in South and Southeast Sulawesi, Indonesia. http://dx.doi.org/10.5716/WP12058.PDF

160. Agroforestry and Forestry in Sulawesi series: Rapid market appraisal of agricultural, plantation and forestry commodities in South and Southeast Sulawesi.

http://dx.doi.org/10.5716/WP12059.PDF

2013

161. Diagnosis of farming systems in the Agroforestry for Livelihoods of Smallholder farmers in Northwestern Viet Nam project http://dx.doi.org/10.5716/WP13033.PDF

162. Ecosystem vulnerability to climate change: a literature review. http://dx.doi.org/10.5716/WP13034.PDF

163. Local capacity for implementing payments for environmental services schemes: lessons from the RUPES project in northeastern Viet Nam http://dx.doi.org/10.5716/WP13046.PDF

164. Seri Agroforestri dan Kehutanan di Sulawesi: Agroforestry dan Kehutanan di Sulawesi: Strategi mata pencaharian dan dinamika sistem penggunaan lahan di Sulawesi Selatan http://dx.doi.org/10.5716/WP13040.PDF

165. Seri Agroforestri dan Kehutanan di Sulawesi: Mata pencaharian dan dinamika sistem penggunaan lahan di Sulawesi Tenggara http://dx.doi.org/10.5716/WP13041.PDF

166. Seri Agroforestri dan Kehutanan di Sulawesi: Profitabilitas sistem penggunaan lahan di Sulawesi Selatan dan Sulawesi Tenggara http://dx.doi.org/10.5716/WP13042.PDF

167. Seri Agroforestri dan Kehutanan di Sulawesi: Gender, mata pencarian dan lahan di Sulawesi Selatan dan Sulawesi Tenggara http://dx.doi.org/10.5716/WP13043.PDF 
168. Seri Agroforestri dan Kehutanan di Sulawesi: Kebutuhan penyuluhan agroforestri pada tingkat masyarakat di lokasi proyek AgFor di Sulawesi Selatan dan Tenggara, Indonesia. http://dx.doi.org/10.5716/WP13044.PDF

169. Seri Agroforestri dan Kehutanan di Sulawesi: Laporan hasil penilaian cepat untuk komoditas pertanian, perkebunan dan kehutanan di Sulawesi Selatan dan Tenggara http://dx.doi.org/10.5716/WP13045.PDF

170. Agroforestry, food and nutritional security http://dx.doi.org/10.5716/WP13054.PDF

171. Stakeholder Preferences over Rewards for Ecosystem Services: Implications for a REDD+ Benefit Distribution System in Viet Nam http://dx.doi.org/10.5716/WP13057.PDF

172. Payments for ecosystem services schemes: project-level insights on benefits for ecosystems and the rural poor http://dx.doi.org/10.5716/WP13001.PDF

173. Good practices for smallholder teak plantations: keys to success http://dx.doi.org/10.5716/WP13246.PDF

174. Market analysis of selected agroforestry products in the Vision for Change Project intervention Zone, Côte d'Ivoire http://dx.doi.org/10.5716/WP13249.PDF

175. Rattan futures in Katingan: why do smallholders abandon or keep their gardens in Indonesia's 'rattan district'? http://dx.doi.org/10.5716/WP13251.PDF

176. Management along a gradient: the case of Southeast Sulawesi's cacao production landscapes http://dx.doi.org/10.5716/WP13265.PDF

2014

177. Are trees buffering ecosystems and livelihoods in agricultural landscapes of the Lower Mekong Basin? Consequences for climate-change adaptation. http://dx.doi.org/10.5716/WP14047.PDF

178. Agroforestry, livestock, fodder production and climate change adaptation and mitigation in East Africa: issues and options. http://dx.doi.org/10.5716/WP14050.PDF

179. Trees on farms: an update and reanalysis of agroforestry's global extent and socio-ecological characteristics. http://dx.doi.org/10.5716/WP14064.PDF

180. Beyond reforestation: an assessment of Vietnam's REDD+ readiness. http://dx.doi.org/10.5716/WP14097.PDF

181. Farmer-to-farmer extension in Kenya: the perspectives of organizations using the approach. http://dx.doi.org/10.5716/WP14380.PDF

182. Farmer-to-farmer extension in Cameroon: a survey of extension organizations. http://dx.doi.org/10.5716/WP14383.PDF

183. Farmer-to-farmer extension approach in Malawi: a survey of organizations: a survey of organizations http://dx.doi.org/10.5716/WP14391.PDF

184. Seri Agroforestri dan Kehutanan di Sulawesi: Kuantifikasi jasa lingkungan air dan karbon pola agroforestri pada hutan rakyat di wilayah sungai Jeneberang

185. Options for Climate-Smart Agriculture at Kaptumo Site in Kenyahttp://dx.doi.org/10.5716/WP14394.PDF

2015

186. Agroforestry for Landscape Restoration and Livelihood Development in Central Asia http://dx.doi.org/10.5716/WP14143.PDF 
187. "Projected Climate Change and Impact on Bioclimatic Conditions in the Central and SouthCentral Asia Region" http://dx.doi.org/10.5716/WP14144.PDF

188. Land Cover Changes, Forest Loss and Degradation in Kutai Barat, Indonesia. http://dx.doi.org/10.5716/WP14145.PDF

189. The Farmer-to-Farmer Extension Approach in Malawi: A Survey of Lead Farmers. http://dx.doi.org/10.5716/WP14152.PDF

190. Evaluating indicators of land degradation and targeting agroforestry interventions in smallholder farming systems in Ethiopia. http://dx.doi.org/10.5716/WP14252.PDF

191. Land health surveillance for identifying land constraints and targeting land management options in smallholder farming systems in Western Cameroon

192. Land health surveillance in four agroecologies in Malawi

193. Cocoa Land Health Surveillance: an evidence-based approach to sustainable management of cocoa landscapes in the Nawa region, South-West Côte d'Ivoire http://dx.doi.org/10.5716/WP14255.PDF

194. Situational analysis report: Xishuangbanna autonomous Dai Prefecture, Yunnan Province, China. http://dx.doi.org/10.5716/WP14255.PDF

195. Farmer-to-farmer extension: a survey of lead farmers in Cameroon. http://dx.doi.org/10.5716/WP15009.PDF

196. From transition fuel to viable energy source Improving sustainability in the sub-Saharan charcoal sector http://dx.doi.org/10.5716/WP15011.PDF

197. Mobilizing Hybrid Knowledge for More Effective Water Governance in the Asian Highlands http://dx.doi.org/10.5716/WP15012.PDF

198. Water Governance in the Asian Highlands http://dx.doi.org/10.5716/WP15013.PDF

199. Assessing the Effectiveness of the Volunteer Farmer Trainer Approach in Dissemination of Livestock Feed Technologies in Kenya vis-à-vis other Information Sources http://dx.doi.org/10.5716/WP15022.PDF

200. The rooted pedon in a dynamic multifunctional landscape: Soil science at the World Agroforestry Centre http://dx.doi.org/10.5716/WP15023.PDF

201. Characterising agro-ecological zones with local knowledge. Case study: Huong Khe district, Ha Tinh, Viet Nam http://dx.doi.org/10.5716/WP15050.PDF

202. Looking back to look ahead: Insight into the effectiveness and efficiency of selected advisory approaches in the dissemination of agricultural technologies indicative of Conservation Agriculture with Trees in Machakos County, Kenya. http://dx.doi.org/10.5716/WP15065.PDF

203. Pro-poor Biocarbon Projects in Eastern Africa Economic and Institutional Lessons. http://dx.doi.org/10.5716/WP15022.PDF

204. Projected climate change impacts on climatic suitability and geographical distribution of banana and coffee plantations in Nepal. http://dx.doi.org/10.5716/WP15294.PDF

205. Agroforestry and Forestry in Sulawesi series: Smallholders' coffee production and marketing in Indonesia. A case study of two villages in South Sulawesi Province. http://dx.doi.org/10.5716/WP15690.PDF

206. Mobile phone ownership and use of short message service by farmer trainers: a case study of Olkalou and Kaptumo in Kenya http://dx.doi.org/10.5716/WP15691.PDF

207. Associating multivariate climatic descriptors with cereal yields: a case study of Southern Burkina Faso http://dx.doi.org/10.5716/WP15273.PDF

208. Preferences and adoption of livestock feed practices among farmers in dairy management groups in Kenya http://dx.doi.org/10.5716/WP15675.PDF 
209. Scaling up climate-smart agriculture: lessons learned from South Asia and pathways for success http://dx.doi.org/10.5716/WP15720.PDF

210. Agroforestry and Forestry in Sulawesi series: Local perceptions of forest ecosystem services and collaborative formulation of reward mechanisms in South and Southeast Sulawesi http://dx.doi.org/10.5716/WP15721.PDF

211. Potential and challenges in implementing the co-investment of ecosystem services scheme in Buol District, Indonesia. http://dx.doi.org/10.5716/WP15722.PDF

212. Tree diversity and its utilization by the local community in Buol District, Indonesia http://dx.doi.org/10.5716/WP15723.PDF

213 Vulnerability of smallholder farmers and their preferences on farming practices in Buol District, Indonesia http://dx.doi.org/10.5716/WP15724.PDF

214. Dynamics of Land Use/Cover Change and Carbon Emission in Buol District, Indonesia http://dx.doi.org/10.5716/WP15725.PDF

215. Gender perspective in smallholder farming practices in Lantapan, Phillippines. http://dx.doi.org/10.5716/WP15726.PDF

216. Vulnerability of smallholder farmers in Lantapan, Bukidnon. http://dx.doi.org/10.5716/WP15727.PDF

217. Vulnerability and adaptive capacity of smallholder farmers in Ho Ho Sub-watershed, Ha Tinh Province, Vietnam http://dx.doi.org/10.5716/WP15728.PDF

218. Local Knowledge on the role of trees to enhance livelihoods and ecosystem services in northern central Vietnam http://dx.doi.org/10.5716/WP15729.PDF

219. Land-use/cover change in Ho Ho Sub-watershed, Ha Tinh Province, Vietnam. http://dx.doi.org/10.5716/WP15730.PDF

2016

220. Agroforestry and Forestry in Sulawesi series: Evaluation of the Agroforestry Farmer Field Schools on agroforestry management in South and Southeast Sulawesi, Indonesia. http://dx.doi.org/10.5716/WP16002.PDF

221. Farmer-to-farmer extension of livestock feed technologies in Rwanda: A survey of volunteer farmer trainers and organizations. http://dx.doi.org/10.5716/WP16005.PDF

222. Projected Climate Change Impact on Hydrology, Bioclimatic Conditions, and Terrestrial Ecosystems in the Asian Highlands http://dx.doi.org/10.5716/WP16006.PDF

223. Adoption of Agroforestry and its impact on household food security among farmers in Malawi http://dx.doi.org/10.5716/WP16013.PDF

224. Agroforestry and Forestry in Sulawesi series: Information channels for disseminating innovative agroforestry practices to villages in Southern Sulawesi, Indonesia http://dx.doi.org/10.5716/WP16034.PDF

225. Agroforestry and Forestry in Sulawesi series: Unravelling rural migration networks.Landtenure arrangements among Bugis migrant communities in Southeast Sulawesi. http://dx.doi.org/10.5716/WP16035.PDF

226. Agroforestry and Forestry in Sulawesi series: Women's participation in agroforestry: more benefit or burden? A gendered analysis of Gorontalo Province. http://dx.doi.org/10.5716/WP16036.PDF

227. Kajian Kelayakan dan Pengembangan Desain Teknis Rehabilitasi Pesisir di Sulawesi Tengah. http://dx.doi.org/10.5716/WP16037.PDF

228. Selection of son tra clones in North West Vietnam. http://dx.doi.org/10.5716/WP16038.PDF 
229. Growth and fruit yield of seedlings, cuttings and grafts from selected son tra trees in Northwest Vietnam http://dx.doi.org/10.5716/WP16046.PDF

230. Gender-Focused Analysis of Poverty and Vulnerability in Yunnan, China http://dx.doi.org/10.5716/WP16071.PDF

231. Seri Agroforestri dan Kehutanan di Sulawesi: Kebutuhan Penyuluhan Agroforestri untuk Rehabilitasi Lahan di Sumba Timur, Nusa Tenggara Timur, Indonesia. http://dx.doi.org/10.5716/WP16077.PDF

232. Agroforestry and Forestry in Sulawesi series: Agroforestry extension needs for land rehabilitation in East Sumba, East Nusa Tenggara, Indonesia. http://dx.doi.org/10.5716/WP16078.PDF

233. Central hypotheses for the third agroforestry paradigm within a common definition. http://dx.doi.org/10.5716/WP16079.PDF

234. Assessing smallholder farmers' interest in shade coffee trees: The Farming Systems of Smallholder Coffee Producers in the Gisenyi Area, Rwanda: a participatory diagnostic study. http://dx.doi.org/10.5716/WP16104.PDF

235. Review of agricultural market information systems in |sub-Saharan Africa. http://dx.doi.org/10.5716/WP16110.PDF

236. Vision and road map for establishment of a protected area in Lag Badana, Lower Jubba, Somalia. http://dx.doi.org/10.5716/WP16127.PDF

237. Replicable tools and frameworks for Bio-Carbon Development in West Africa. http://dx.doi.org/10.5716/WP16138.PDF

238. Existing Conditions, Challenges and Needs in the Implementation of Forestry and Agroforestry Extension in Indonesia. http://dx.doi.org/10.5716/WP16141.PDF

239. Situasi Terkini, Tantangan dan Kebutuhan Pelaksanaan Penyuluhan Kehutanan dan Agroforestri di Indonesia. http://dx.doi.org/10.5716/WP16142.PDF

240. The national agroforestry policy of India: experiential learning in development and delivery phases. http://dx.doi.org/10.5716/WP16143.PDF

241. Agroforestry and Forestry in Sulawesi series: Livelihood strategies and land-use system dynamics in Gorontalo. http://dx.doi.org/10.5716/WP16157.PDF

242. Seri Agroforestri dan Kehutanan di Sulawesi: Strategi mata pencaharian dan dinamika sistem penggunaan lahan di Gorontalo. http://dx.doi.org/10.5716/WP16158.PDF

243. Ruang, Gender dan Kualitas Hidup Manusia: Sebuah studi Gender pada komunitas perantau dan pengelola kebun di Jawa Barat. http://dx.doi.org/10.5716/WP16159.PDF

244. Gendered Knowledge and perception in managing grassland areas in East Sumba, Indonesia. http://dx.doi.org/10.5716/WP16160.PDF

245. Pengetahuan dan persepsi masyarakat pengelola padang aavana, Sebuah Kajian Gender di Sumba Timur. http://dx.doi.org/10.5716/WP16161.PDF

246. Dinamika Pengambilan Keputusan pada komunitas perantau dan pengelola kebun di Jawa Barat. http://dx.doi.org/10.5716/WP16162.PDF

247. Gaharu (eaglewood) domestication: Biotechnology, markets and agroforestry options. http://dx.doi.org/10.5716/WP16163.PDF

248. Marine habitats of the Lamu-Kiunga coast: an assessment of biodiversity value, threats and opportunities. http://dx.doi.org/10.5716/WP16167.PDF

249. Assessment of the biodiversity in terrestrial landscapes of the Witu protected area and surroundings, Lamu County Kenya. http://dx.doi.org/10.5716/WP16172.PDF

250. An ecosystem services perspective on benefits that people derive from biodiversity of Coastal forests in Lamu County, Kenya http://dx.doi.org/10.5716/WP16173.PDF 
251. Assessment of the biodiversity in terrestrial and marine landscapes of the proposed Laga Badana National Park and surrounding areas, Jubaland, Somalia. http://dx.doi.org/10.5716/WP16174.PDF

2017

252. Preferensi Petani terhadap Topik Penyuluhan dan Penyebaran Informasi Agroforestri di Indonesia. http://dx.doi.org/10.5716/WP16181.PDF

253. Seri Agroforestri dan Kehutanan di Sulawesi: Keanekaragaman hayati jenis pohon pada hutan rakyat agroforestri di DAS Balangtieng, Sulawesi Selatan. http://dx.doi.org/10.5716/WP16182.PDF

254. Potensi dan Tantangan dalam Pengembangan Skema Ko-Investasi Jasa Lingkungan di Kabupaten Buol, Indonesia. http://dx.doi.org/10.5716/WP17008.PDF

255. Keragaman Jenis Pohon dan Pemanfaatannya oleh Masyarakat di Kabupaten Buol, Indonesia. http://dx.doi.org/10.5716/WP17009.PDF

256. Kerentanan dan preferensi sistem pertanian petani di Kabupaten Buol, Indonesia. http://dx.doi.org/10.5716/WP17010.PDF

257. Dinamika Perubahan Penggunaan/Tutupan Lahan Serta Cadangan Karbon di Kabupaten Buol, Indonesia. http://dx.doi.org/10.5716/WP17011.PDF

258. The Effectiveness of the Volunteer Farmer Trainer Approach vis-à-vis Other Information Sources in Dissemination of Livestock Feed Technologies in Uganda. http://dx.doi.org/10.5716/WP17104.PDF

259. Agroforestry and Forestry in Sulawesi series: Impact of agricultural-extension booklets on community livelihoods in South and Southeast Sulawesi. http://dx.doi.org/10.5716/WP17125.PDF

260. Petani Menjadi Penyuluh, Mungkinkah? Sebuah Pendekatan Penyuluhan dari Petani ke Petani di Kabupaten Sumba Timur. http://dx.doi.org/10.5716/WP17145.PDF

261. Dampak Perubahan Tutupan Lahan terhadap Kondisi Hidrologi di Das Buol, Kabupaten Buol, Sulawesi Tengah: Simulasi dengan Model Genriver. http://dx.doi.org/10.5716/WP17146.PDF

262. Analisis Tapak Mata Air Umbulan, Pasuruan, Jawa Timur. Kajian elemen biofisik dan persepsi masyarakat. http://dx.doi.org/10.5716/WP17147.PDF

263. Planned comparisons demystified. http://dx.doi.org/10.5716/WP17354.PDF

264. Soil health decision support for NERC digital soil platforms: A survey report. http://dx.doi.org/10.5716/WP17355.PDF

265. Seri Pembangunan Ekonomi Pedesaan Indonesia: Menanam di bukit gundul: Pengetahuan masyarakat lokal dalam upaya restorasi lahan di Sumba Timur. http://dx.doi.org/10.5716/WP17356.PDF

266. Tree diversity and carbon stock in three districts of Kutai Timur, Pasir and Berau, East Kalimantan http://dx.doi.org/10.5716/WP17357.PDF 

The World Agroforestry Centre is an autonomous, non-profit research organization whose vision is a rural transformation in the developing world as smallholder households increase their use of trees in agricultural landscapes to improve food security, nutrition, income, health, shelter, social cohesion, energy resources and environmental sustainability. The Centre generates science-based knowledge about the diverse roles that trees play in agricultural landscapes, and uses its research to advance policies and practices, and their implementation that benefit the poor and the environment. It aims to ensure that all this is achieved by enhancing the quality of its science work, increasing operational efficiency, building and maintaining strong partnerships, accelerating the use and impact of its research, and promoting greater cohesion, interdependence and alignment within the organization.

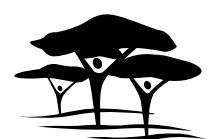

United Nations Avenue, Gigiri • PO Box 30677 • Nairobi, $00100 \cdot$ Kenya Telephone: +254 207224000 or via USA +1 6508336645 Fax: +254207224001 or via USA +1 6508336646

Email: worldagroforestry@cgiar.org•www.worldagroforestry.org

Southeast Asia Regional Program • Sindang Barang • Bogor 16680

PO Box $161 \cdot$ Bogor $16001 \cdot$ Indonesia

Telephone: +62 2518625415 • Fax: +62 2518625416

- Email: icraf-indonesia@cgiar.org

www.worldagroforestry.org/region/southeast-asia

blog.worldagroforestry.org 